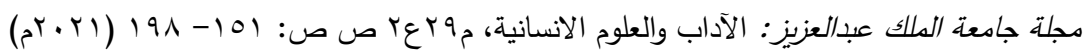

DOI:10.4197/Art.29-2.7

\title{
تعقّبات جامع العلوم الباقولي للأخفش في شرحه لكتاب اللمع عرض ومناقشة
}

\author{
أ.د. إبراهيم بن سالم الصاعدي \\ أستاذ اللغويات بكلية اللغتة العربية بالجامعة الإسلامية بالمدينتة المنورة \\ وعميد الخريجين والتعاون الدولهي بالجامعة
}

مستخلص. يتتاول البحث تعقّبات جامع العلوم الباقولي للأخفش في كتابه شرح اللمع، وبدأت البحث بتمهيد يشمل

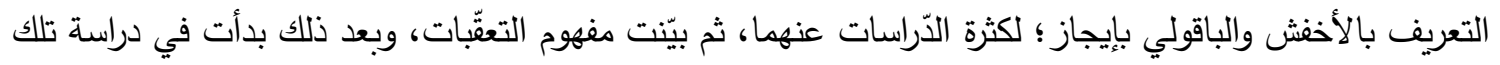

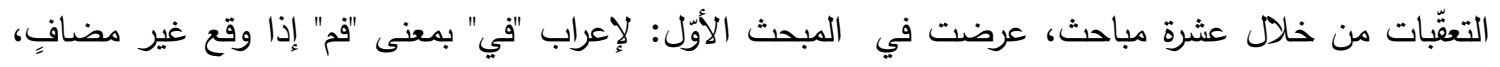
وتحدّثت في المبحث الثّاني عن رفع الفاعل بالجارّ والمجرور، ثم خصّصت المبحث الثالث لإعمال "لات" ، وتحدثت في المبحث الرّابع عن عامل النصب في المفعول معاه، وأفردت المبحث الخامس للحديث عن العطف على معدولي عاملين، وخصصت المبحث السادس عن تقديم الحال على العامل فيها إذا كان ظرفاً ، ثم فصّلت القول في المبحث السّابع عن العامل في الصّفة، وبيان آراء النّحاة في ذلك، وفي المبحث الثّامن تحدّثت عن "أي" بين الصّفة والموصول، ثم عرضت في المبحث التّاسع لـ "ما" المصدرية بين الاسميّة والحرفية، ثم ختمت الحديث في المبحث العاشر عن معنى "ما" التّعجبية في " ما أفعله " ، وقد سرت في دراسة هذه المسائل على المنهج الوصفي

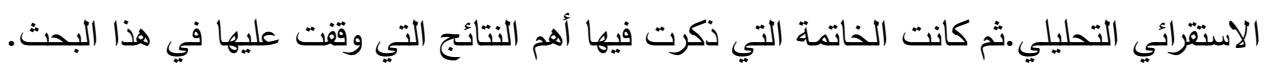
الكلمات المفتاحية : تعقّات ـ الباقولي ـ الأخفش ـ شرح اللمع

المهمة؛ إذ تُوقف الباحث على طريقة العلماء ومنهجه في عرض الآراء ونقدها وتفنيدها، ومن خلال القراءة في كتاب شرح اللمع لجامع العلوم الباقولي رأيت هذه الظاهرة واضحة للعيان ؛ إذ تجده يتعقبّ آراء العلماء ويقف منها مواقف متعددة، ومما لاشكّ فيه أنّ التعقّب أو الاستدراك أو الاعتراض من السّمات البارزة في كتب النحو والصّرف خاصّة،

\section{المقدّمةه}

إنّ الحمد لله، نحمده، ونستعينه، ونستغفره، المعده، ونستهديه، ونعوذ بالله من شرور أنفسنا وسيئات أعمالنا؛ من يهده الله فلا مضلّ لله، ومن يضلل فلا هادي لله، وأشهد أن لا إله إلاّ الله وحده لا شريك له، وأشهد أنّ محمداً عبده ورسوله. وبعد؛ فإنّ دراسة التعقبّات من الموضوعات 
المطلب الثّالث: مفهوم التعقبّات.

المبحث الأوّل: إعراب " في " بمعنى " فم " إذا لعنات

وقع غير مضافٍ .

المبحث الثّاني: رفع الفاعل بالجارّ والمجرور أو

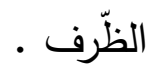

المبحث الثالث: إعمال "لات".

المبحث الرّابع: عامل النصب في المفعول معله.

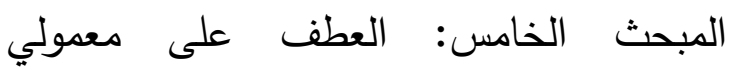

عاملين.

المبحث السادس: تقديم الحال على العامل فيها

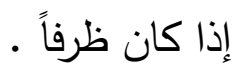

المبحث السّابع: العامل في الصّفة.

المبحث الثّامن: "أي" بين الصّفة والموصول.

المبحث التّاسع: "ما" المصدرية بين الاسميّة لينة

والحرفية.

المبحث العاشر: معنى "ما" التعجبة في " ما

أفعله ".

الخاتمة ، ثم الفهارس المتتوعة.

$$
\text { منهج البحث: }
$$

منهج البحث وصفيّ استقرائي تحليلي، وفق

$$
\text { الخطوات الآتية: }
$$

1 -دراسة المسائل الواردة في البحث، وبيان آراء

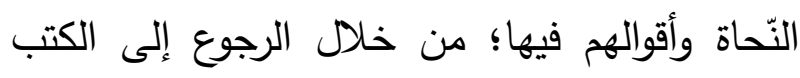

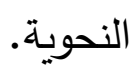

وهذا البحث ييرز لنا جانباً مهماً لكتاب شرح اللمع

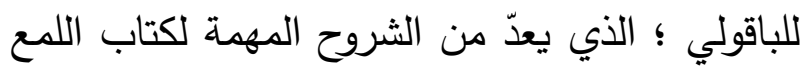

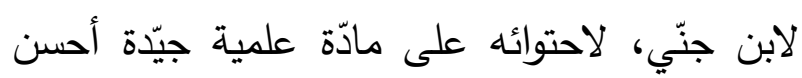
الباقولي عرضها وؤفِقَّ في ترتيبها ونظمها. أسباب اختيار الموضوع :

1- الوقوف على شخصية الباقولي النّحوية؛ من خلال الدّراسة المتعمّقة لتعقّباته على الأخفش.

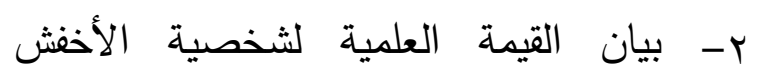
النحوية.

r- قيمة كتاب"شرح اللمع" العلمية، ومايحويه من آراء العلماء وأقوالهم في المسائل النحوية.

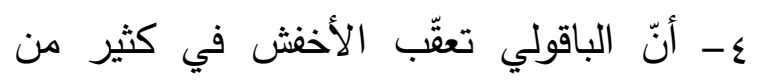
المسائل مخطئًا إياه في أغلبها، فكان البحث للتأكد من تلك التعقّبات، وهل كان الباقولي محقِّاً فيها؟

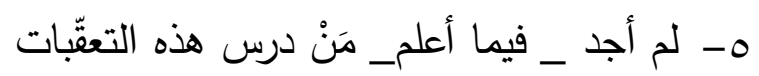
أو أفردها ببحث مستقلّ. خطّة البحث:

اقتضت طبيعة هذا البحث أن يتألف من

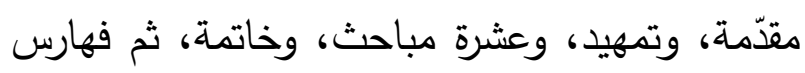
متتوعة.

المقدّمة، وفيها بيان أهمية الموضوع، وأسباب اختياره، وخطة البحث، والمنهج المتبع فيه. التمهيد: التعريف بالأخفش والباقولي، وبيان ولتهن مفهوم التعقّبات، وفيه ثلاثة مطالب: المطلب الأوّل: الأخفش: حياته وآثاره بإيجاز . المطلب الثّاني: الباقولي: حياته وآثاره بإيجاز • 
أحمد الفراهيدي، وسيبويه، ويونس بن حبيب، وأبي

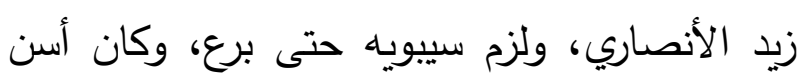
من سيبويه، وعن طريقه عُرِف كتاب سيبويه؛ إذ قرأ عليه الكتاب كل من أبي عمر الجرمي وأبي عثمان ونئه المازني والكسائي. وكان من أكبر أئمة نحاة البصرة بعد شيخه سيبويه، وقد خالف شيخه في كثير من المسائل النحوية والصرفية. ألف الأخفش الكثير من الكتب، طبع منها (؟) .

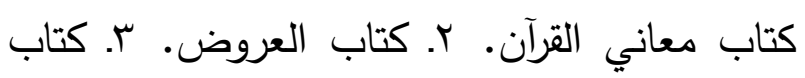

$$
\text { القوافي. }
$$

وله كتب مفقودة، منها: المسائل الكبير، والمسائل الصغير، وكتاب الأوسط في النحو وكتاب الاشتقاق، وكتاب معاني الثعر ، وكتاب المقاييس في ولي لإني

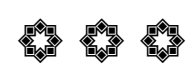

النحو.

المطلب الثّاني : الباقولي: حياته و وآثاره

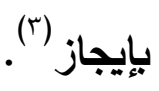

هو أبو الحسن علي بن الحسين بن علي الفي

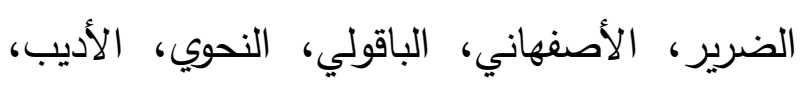

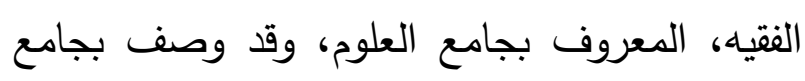

(r) ينظر : مقدمة تحقيق الدكتور أحمد عبدالدايم لكتاب العروض صلو وما بعدها.

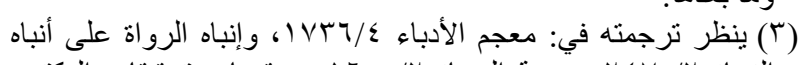

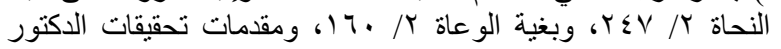

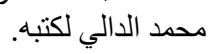

ץ-توثيق الأقوال والآراء الواردة في البحث بالرجوع إلى مؤلفات أصحابها إن تيسرت؛ وإلاًّ فمن الصن كتب النحو المعتمدة.

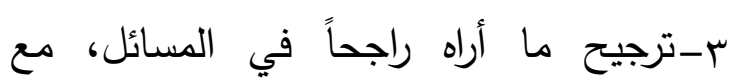

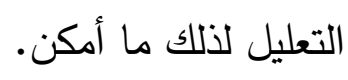

ع-ترتيب المسائل في البحث وفق ورودها في كتاب شرح اللمع. ه-عزو الآيات القرآنية إلى سورها، مع ذكر اسم السورة ورقم الآية وكتابتها بالرسم العثماني. ج-توثيق القراءات القرآنية من مظانها المعتمدة.

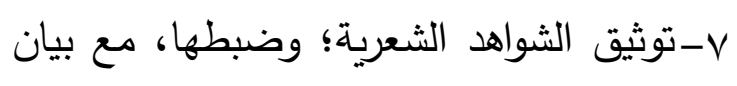
بحر البيت، وقائله -إن أمكن -. وبالله التوفيق.

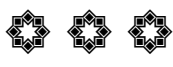

التمهيد: التّعريف بالأخفش والباقولي وبيان

مفهوم التعقبّات. المطلب الأوّل: الأخفش: ياته وآثاره بايجاز (')

هو أبو الحسن سعيد بن مَسْعَدة المجاشعي

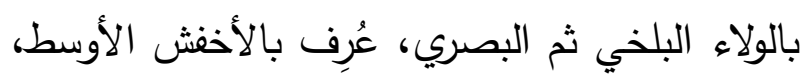

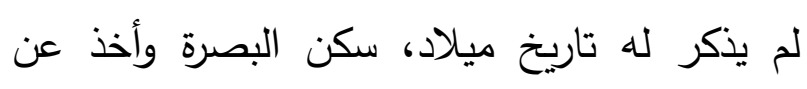
علمائها ثم رحل إلى بغداد في آخر حياته، وما زال

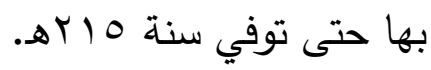
ويعد الأخفش من جهابذة علماء القرن الثالث الهجري في النحو واللغة والأدب، أخذ عن الخليل بن علن الخدن الخداء

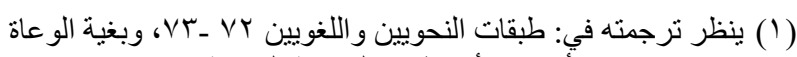

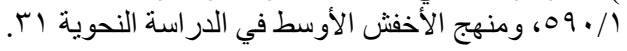


T. ما تلحن فيه العامة في التنزيل. V. مسائل

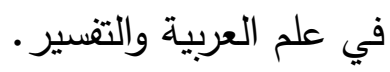

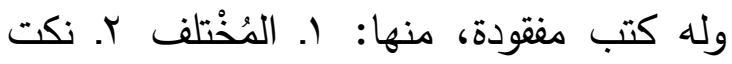
الأقاويل r. الملنّص في الوقف والابتداء ع. البيان في شواهد القرآن.

\section{燯}

المطلب الثالث: مفهوم التعقّبات.

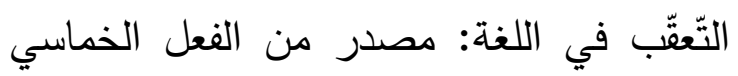
تعقّب، وأصله عَقَب، قال ابن فارس: (العين والقاف

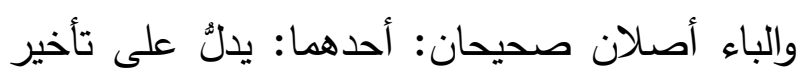

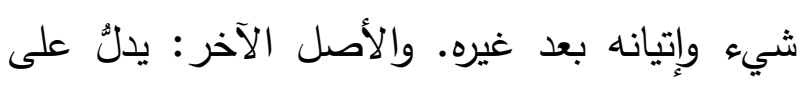

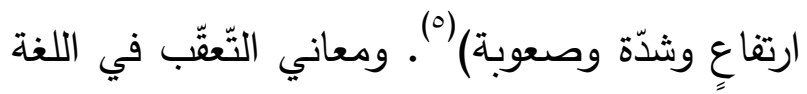

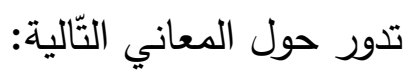
1-آخر الثيء؛ قال الجوهري: "عاقبة كلّ شيء: آخره، وقولهم: ليست لفلان عاقبة؛ أي:

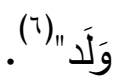

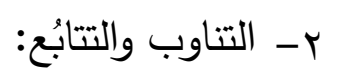

والعُقْبَةُ: النوبة؛ تقول: تمَّت عُقبتُك، وهما يتعاقبان

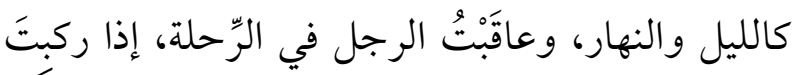

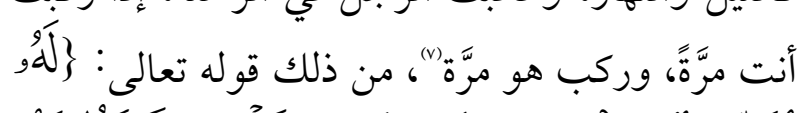

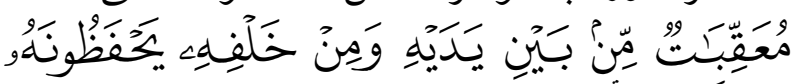

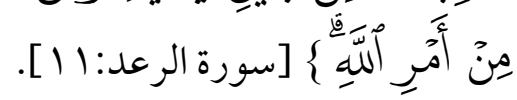

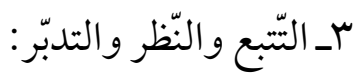

العلوم لغزارة علمه وكثرة مؤلفاته ومصنفاته في عدة من فنون العلم وإتقانه لها، ولم تذكر كتب التراجم تاريخ ميلاده، وشيوخه وتلاميذه. كان واحدا من كبار علماء العربية في عصره، ونيدهاه

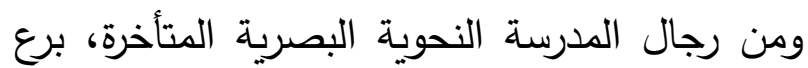

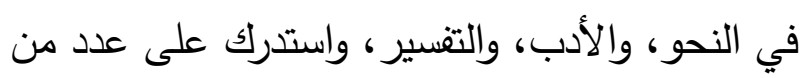
العلماء السابقين؛ منهم الفسوي وعبد القاهر (') ولمكانته العلمية الفائقة في النحو والإعراب قال عنه وعند أبو الحسن البيهقي في كتاب الوشاح: "هو في النحو والاعراب كعبة لها أفاضل العصر سدنة، وللفضل فئل

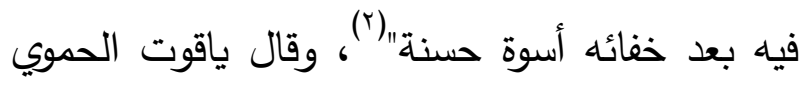
عن نبوغه العلمي: "ومن نظر في تصانيفه علم أنه

لاحق سَبَق السابقين"|("). وتوفي الباقولي: سنة بـ مه، وله مؤلفات عدة،

طبع منها (₹): ا. الإبانة في تقصيل ماءات القرآن وتخريجها على الوجوه التي ذكرها أرباب الصّناعة. r. الاستدراك على أبي علي في الحجّة. جواهر القرآن ونتائج الصّنعة. ع. شرح اللمع. م. كثف المشكاتجلات وإيضاح

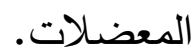

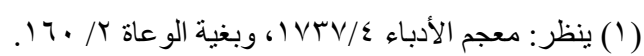

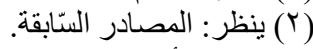

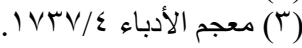
(ع) ينظر مقدمة تحقيق الدكتور الدالي لكتاب جواهر القرآن ونتائج الصّنعة صـ أ وما بعدها. 
فإنّ التقدير فيه: "وفاها " على تقدير المضاف

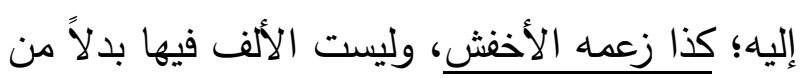

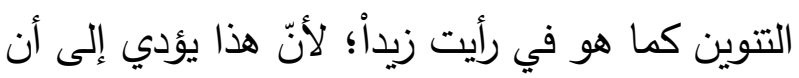
يكون الاسم المتمكّن على حرف واحده (॰).

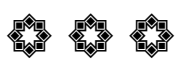

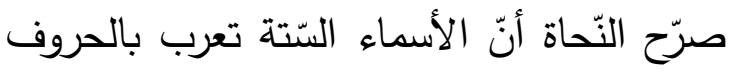

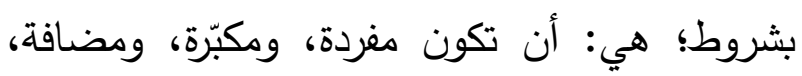

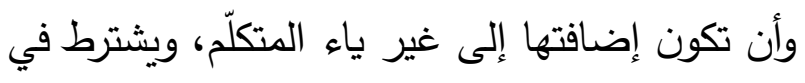

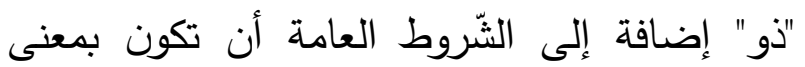

صاحب، ويشترط في "فم" أن تزول منه الميم (؟).

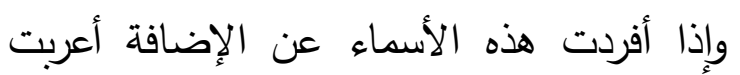

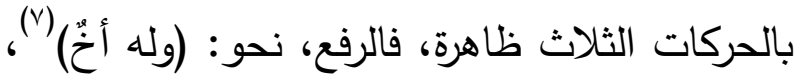

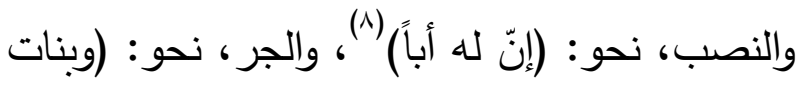

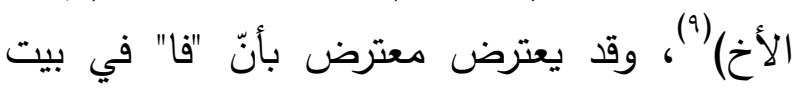

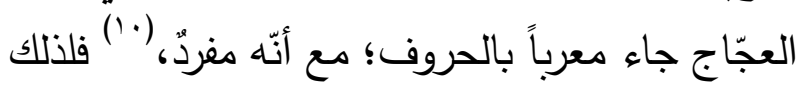

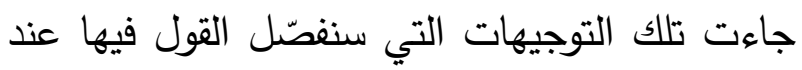
الحديث عن البيت، وما جاء فيه من آراء للنّحاة.

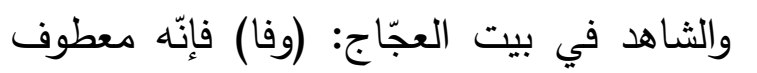
على خياشيم ـ المنصوب بـ خالط على المفعولية .

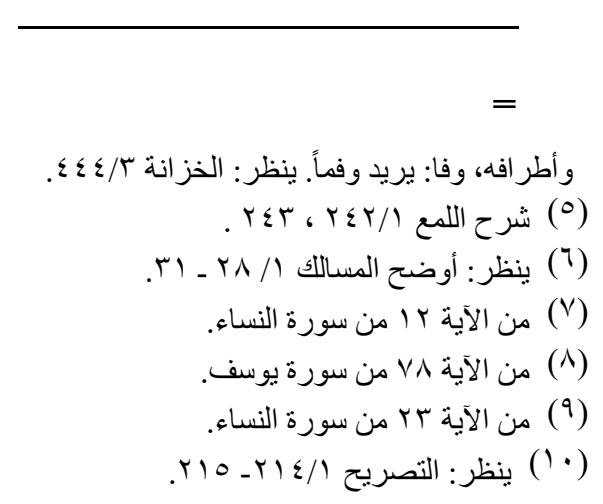

جاء في اللسان: (تعقّب الخبر: تتبعه. ويقال: تعقّبت الأمَر إذا تدبّرته. والتعقّب: التدبّر، و النّظر ثانيةًا)

$$
\text { عـ النقض والزَّد: }
$$

قال الرازي: (يُقَّال: عَقَّبَ الحاكِم على حُكْمِ

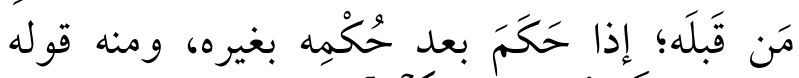

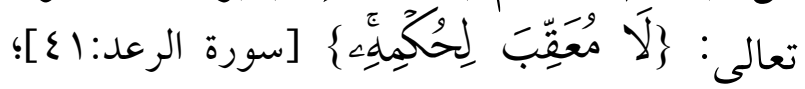

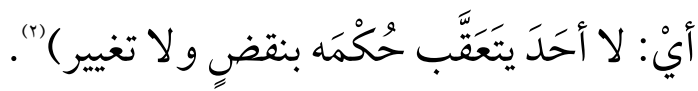
التعقّب في الاصطلاح: بناء على ما سبق من المعاني اللغوية فإنّ مفهوم " التعقبات " لم يخرج عن هذه لفئ المعاني

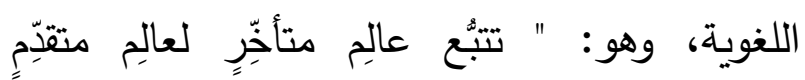

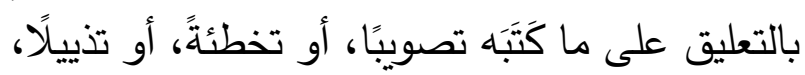

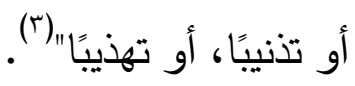

\section{零糸}

المبحث الأول: إعراب " في " بمعنى " فم " إذا هما وقع غير مضافٍ. قال الباقولي: إفأمّا قول العجّاج: خَالَََّ مِنْ

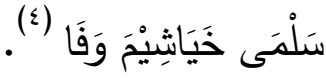

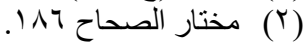

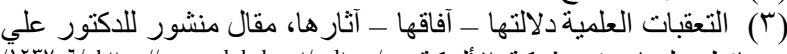

حوجظ سليمان في شبكة الألوكة.

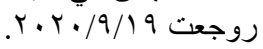

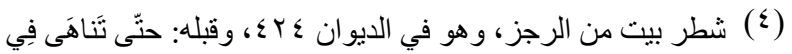

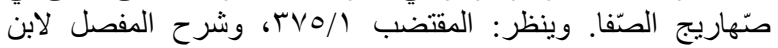

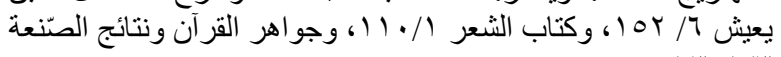
$1 \% \cdot 1 / 4$ وخالط: الضمير المستكن فيه للماء المذكور في الأبيات قبله، والخياشيم: جمع خيشوم، وهو أقصى الأنف، وإنما جمع الخياثيم باعتبار أجزائه 
وقال أبو حيّان . شارحاً كلام ابن مالك في

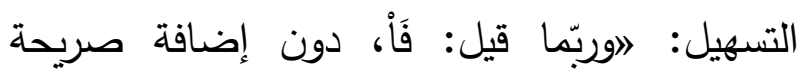
نصباً، (") اويشعر قوله: وربّما قيل؛ بالتقليل، وهذا لم يُسمع منه إلا هذا، وهو من ضرائر الثّّعر الذي لئي

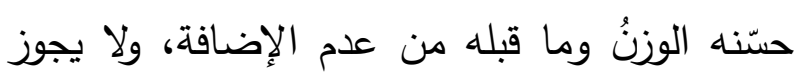

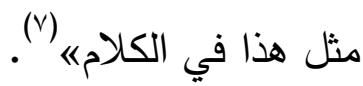
وساق الدّماميني نصّاً عن ابن هشام جاء فيه:

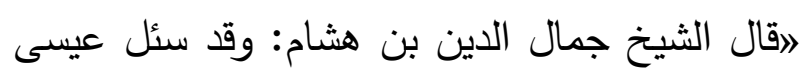

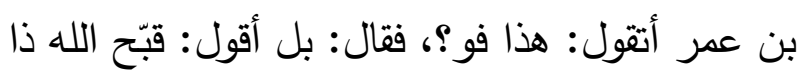
فاً. قال: وذلك دليل على أنى أنّه يجوز وإن لم تكن إضافة ألبتة لا صريحة ولامنويةه (^). وبيّن الدكتور المفدّى محشّياً على هذا الكلهام

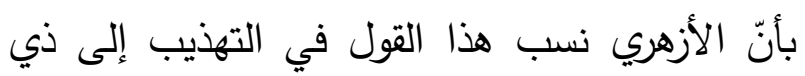
الرمة عن الأصمعي عن بشر بن عمر (9).

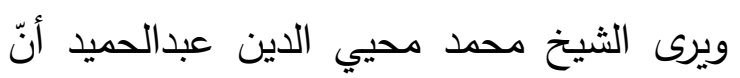
كل ما في البيت أننا نتوسّع في شرط الإضافة،

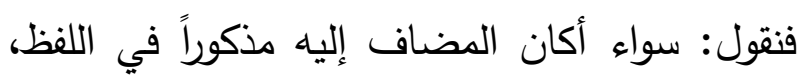
وهو الغالب، أم كان مقدراً، وهو قليل، وهذا البيت البهات

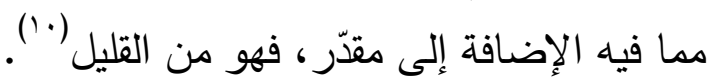
وهو في كلامه هذا متأثر بما قاله خن خالد الإل

(7) (التسهيل: 9.

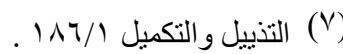

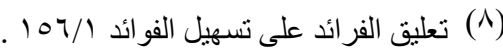

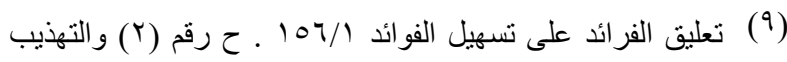
. ₹1/10

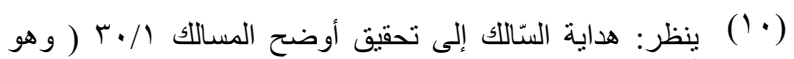
تحقيق أوضح المسالك ).
وهو منصوب بالألف؛ لأتّه من الأسماء السّتة، مع

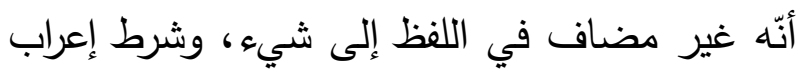
الأسماء اللستّة بالحروف الإضافة ، ومن هنا جاءت

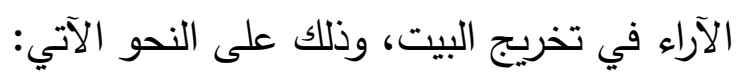

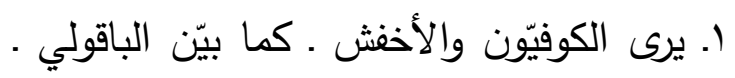

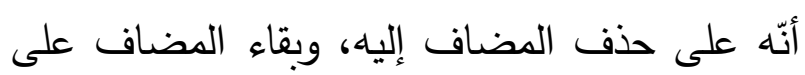

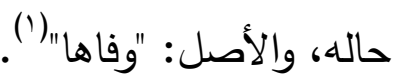
وقد نَسَبَ هذا الرأي إلى الأخفش أبو علي

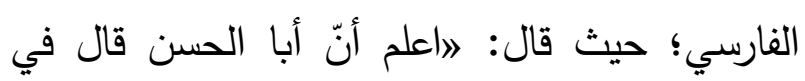
قول الراجز : خَالَطَ مِنْ سَلْمَى خَيَاثِيَِْ وَفَا إنّ التقدير : وفاها، فحذف المضاف إليه، وكذلك

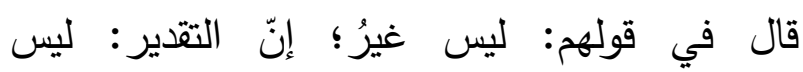

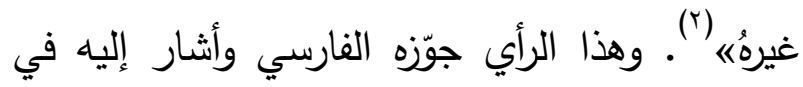
كثير من كتبه (r). وتابع ابن مالك الأخفش في رأيه؛ فقال عن

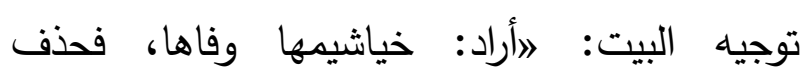
المضاف إليه ونوى الثبوت، وأبقى المضاف على الحال التي كان عليهاه (؛).

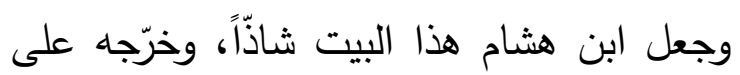

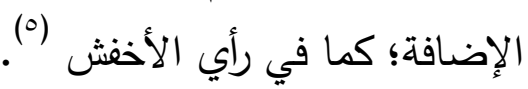

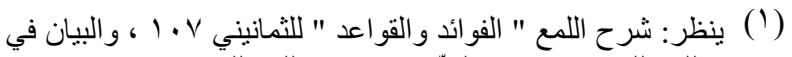

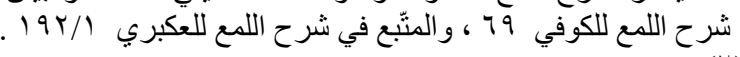

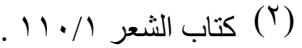

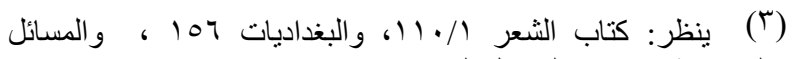

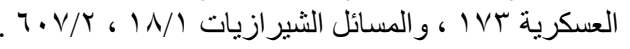

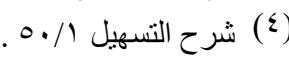

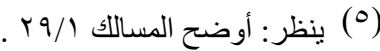


اوحكى بعضهم أنّ من النّاس مَنْ قد لحَّنه، والتلحين

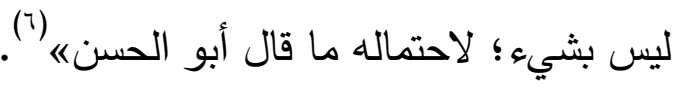

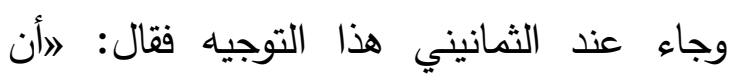

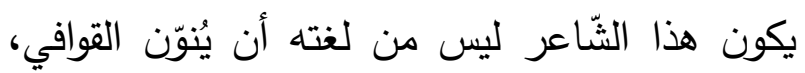

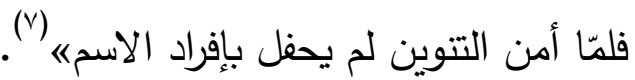

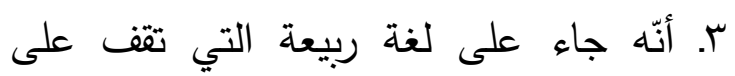
الاسم المنوّن بالسكون، ولا تبدل من التنوين ألفاً، فالألف في "وفا" عين الكلمة (^).

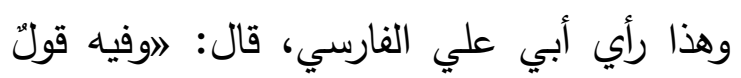
آخرُ : وهو أنّه جاء به على قول من لم يُبدل من التي

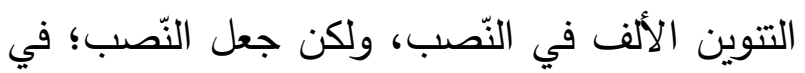

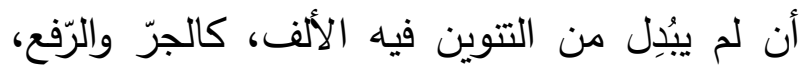
كما جعلوا النّصب في نحو: كن

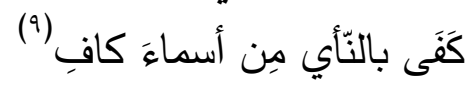

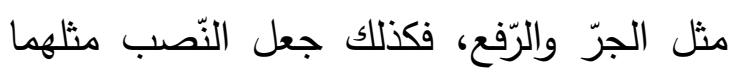
في نحو قوله: - مانه

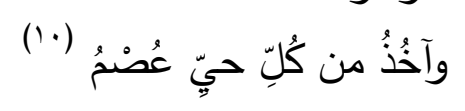

وهذه اللغة ـ وإن لم يحكها سيبويه ـ فقد حكاها

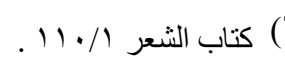

(V)

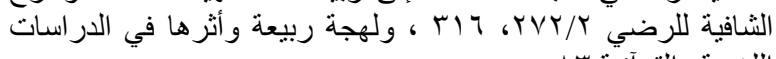

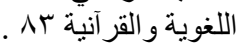

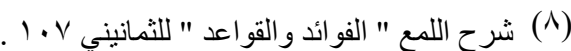

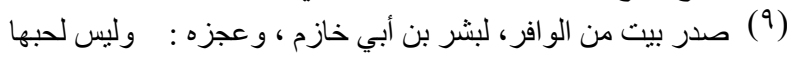

$$
\begin{aligned}
& \text { إذ طال شافٍ }
\end{aligned}
$$

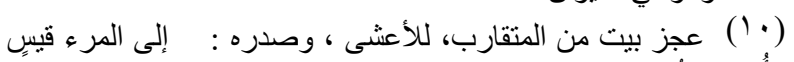

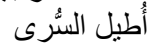

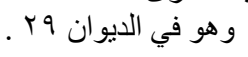

الأزهري: افعلى قول ابن مالك: لا يشترط في الإضافة أن تكون ملفوظة، يل الملفوظة والمنوية سواء《 ") (1). r. يرى بعض النّحاة أنّ هذا لحن، كما نقل عنهم ذلك المبرد، فقال: الوقد لحّن كثير من النّاس

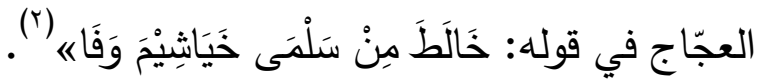
لكنّ المبرد لم يرتض هذا الكلام فقال: لاوليس

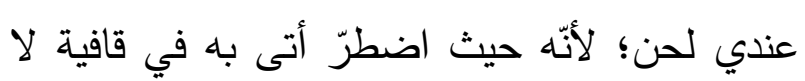
يلحقه معها التتوين في مذهبه. ومن كان يرى تتوين القوافي فيقول: أَقَلِّي اللوحَ

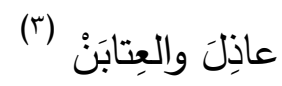
لم يُّوّن هذا؛ لأنّ ترك التتوين هو الأكثر الأغلب، لما في هذا الاسم من الاعتلاله (๕).

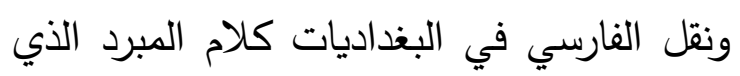
أشار فيه إلى رأي مَنْ يُلحّن البيت، وردّ عليه بقوله: ״فلا يصلح تلحينه ونحن نجد مساغاً إلى تجويزه، ونرى في كلامهم نظيره من استعمالهم في الثعر وإجازتهم فيه ما لا يُجيزون في غيره ولا يستعملون مع سواهن (०). وحكى الفارسي ذلك في كتابه الشعر، فقال:

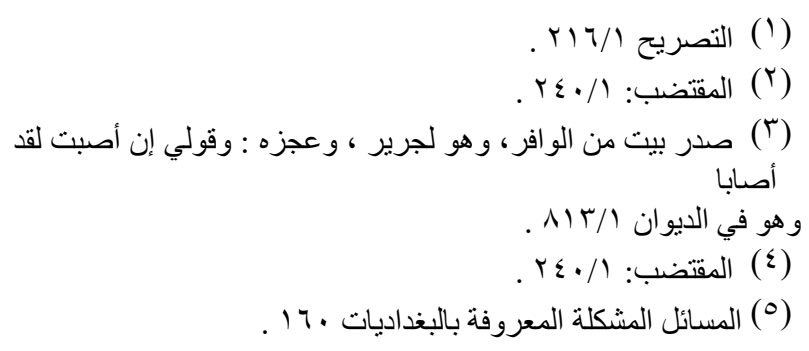


ذلك أن يبقى على حرف واحده '•.

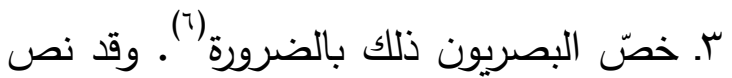
على ذلك الخليل بن أحمد في العين، فقال: 》أما إذا لم تُضَفْ فإنّ الميم تُجْعَلُ عماداً للفاء، لأن الياءَ والواوَ والألَفِتَ يَسُُطنَ مع التَّوين، فكرهوا أن يكون

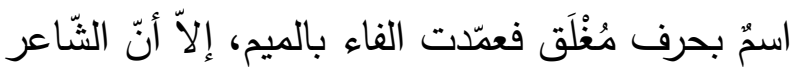
قد يُضْطَرُّ إلى إفراد ذلك بلا ميم، فيجوز في القافية،

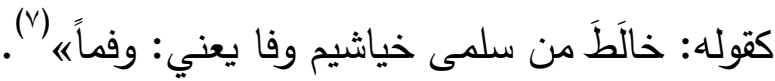
ونصّ الباقولي أيضاً في كتابه جواهر القرآن

على أنّ هذا البيت موضع ضرورة (^). وكلام الفارسي يوضّح ذلك، قال: افحكم هذه الألف في قوله: "وفا" أن تكون بدلاً من التتوين، والمنقلبة من العين سقطت لالتقاء السّاكنين؛ لأنّه السّاكن الأوّل، وبقي الاسم على حرف واحدٍ، وجاز هذا في الشعر للضرورة؛ لأنّه قد يجوز في الثّعر الثر كثرِر مدّا لا يجوز في الكلامه" (9). والمتأمّل في كلام الفارسي الذي سقناه في هذه المسألة يظهر له أنّه مضطرب في رأيه، بين الضرورة كما في كتابيه المسائل البغداديات والعسكريات، أو مجيئه على لغة ربيعة كما في كتابه

(0) التذييل و التكميل 110/1 ـ وينظر : التصريح 10/1 بق فقد نسبه أيضاً

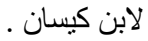

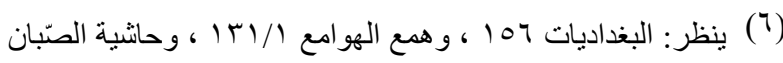
6 VY/

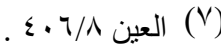

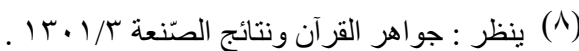

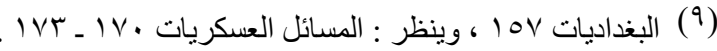

أبو الحسن وغيره، ووجهها من القياس ما أعلمتك. فإذا جاز أن يقدّر على هذه اللغة قدّرناه عليها، فكانت الألف في الكلمة التي هي بدلّ من عين الفعل، وجاز ذلك؛ لأنّه ليس يبقى الاسم المتمكّن على حرف؛ ألا ترى أنّ الألف منقلبة عن العين، فصار في ذلك كالأسماء التي لمّا أُمن لَحاقُ التتوين بها، جاز أن تبقى على حرفين؛ أحُدها حرفُ لين، كقوله: "ذو" التي في معنى "الذي" و "ذا" و "تا" ونحو ذلك، ممّا جاء على حرفين، أحدهما حرفُ لين، لمّا لم يكن ممّا يلحقه التتوين. فكذلك قوله: "خياشيم وفا" لا يمتنع أن يكون على حرفين، أحدُهما حرفُ لين، على الوجه الذي ذكرناه ('). وكلام الفارسي هذا فيه ردّ لكلام الباقولي الذي ذكره تتميماً لحديثه عن البيت؛ إذ قال: الوليست الألف فيها (r) بدلاً من التتوين كما هو في رأيت زيداً؛ لأنّ هذا يؤدي إلى أن يكون الاسم المتمكّن على

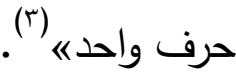
وهذا الرأي نسبه أبو حيّان، والمرادي (£) إلى ابن كيسان، قال أبو حيّان: إفتأوله ابن كيسان على أنّه جاز ذلك لأنّّه موضع لا يلحقه التتوين فحذف، يعني: فحذف التوين، وبقي مغرداً على حرفين، إذ الألف هي المنقلبة عن عين الكلمة، فلم يلزم من

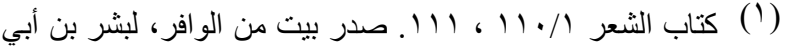

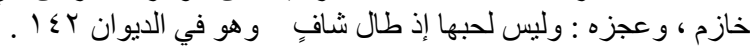

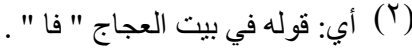
.

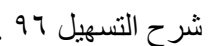


الكلام.

وإن قلت: أحمل قوله "إله" على الضمير الذي في الظرف، أعني "في السماء" فهو وجه، فيكون بمنزلة "الحق" في قوله: "والوزن يومئذ الحق" إلا أنّ الوجه الأول أحسن؛ لأنّ قوله: "وفي الأرض إله" في صلة "الذي" وهو داخل في الصّلة، فلا يبدل عن الضمير ؛ لأنّ البدل يجيء بعد تمام الموصوله (؟).

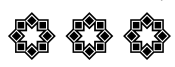

من خلال مراجعة هذا النصّ الذي أورده الباقولي نجد أنّه ذكر في إعراب هذه الآيات أربعة توجيهات، بيانها فيما يأتي: ا. أنّ "إله" فاعل بالظّرف "في السّماء" وهذا

الرأي نسبه الباقولي إلى الأخفش (r). ولم يرتض الباقولي هذا الرأي؛ لخلو جملة الصّلة من العائد، قال: لإذ لا ضمير في قوله: كئح

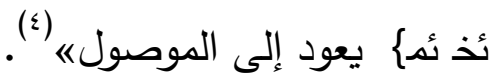
وقال أيضاً الباقولي في الجواهر : لاوإن كان بالظّرف لم يحتمل الظّرف ضميراً مرفوعاً لارتفاع الظّاهر به، وإذا كان كذلك بقيت الصّلة لا ذكر فيها للموصول" (ن) وقال في الكشف: اولا يرتفع بالظّرف أيضاً؛

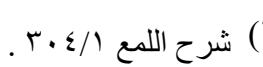

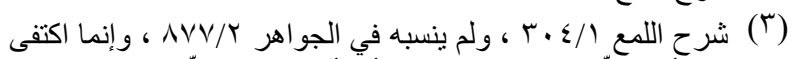

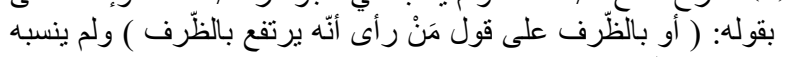

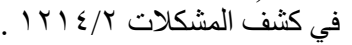

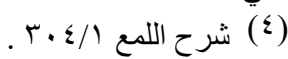

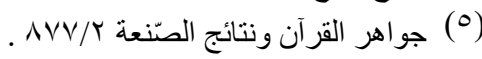

الشعر ؛ فليتتبّه لذلك. وعبارة الباقولي · رحمه الله . عندما ذكر كلام الأخفش صدّرها بقوله: لاكذا زعمه الأخفشه وفي هذا دلالة على عدم موافقته للأخفش فيما ذهب إليه، ولم يتعرّض للبيت في بقية كتبه المطبوعة إلا ما جاء في كتابه جواهر القرآن من أنّ ذلك موضع ضرورة، وهو رأي البصريين الذين يخصون ذلك بالضرورة، وهذا ما أرجّحه في هذه المسألة، وبالله

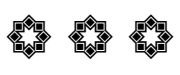

المبحث الثّاني: رفع الفاعل بالجار والمجرور

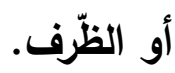

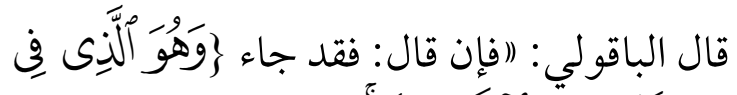

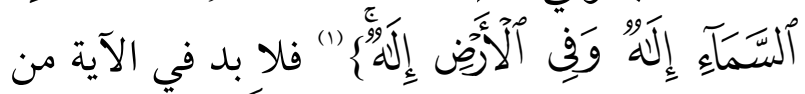

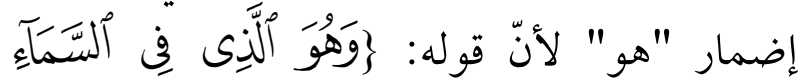
إلَّه" إله إله: رفع والذي ارتقع به لايخلو، إمّا أن يكون "هو" المقدر الذي ادعيناه، أو بالابتداء (وفي السماء) الخبر على زعمكم، أو بالظّرف على زعم أبي الهي الحسن، وكلاهما غير واقع؛ إذ لا ضمير في قوله: (في السماء إله) يعود إلى الموصول فثبت أنّه على إضمار "هو" فالجواب أن حذف "هو" في الآية سائغ لطول الكلام، وطول الكلام يحتمل معه ما لا يحتمل مع غيره، ألا ترى أنهّ قالوا: لولا زيد لهلك عمرو، فألزموا حذف خبر المبتدأ في هذا الباب لطول 


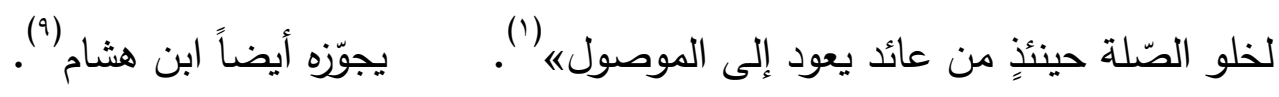
". أنّ "إلهه" خبر لمبتدأ محذوف، تقديره: "هو"

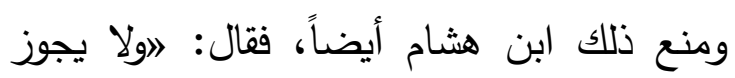

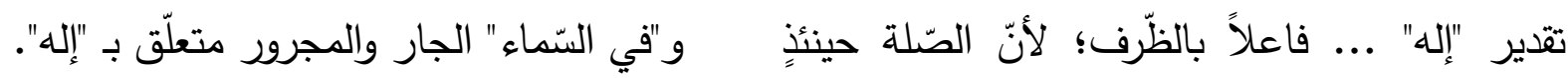

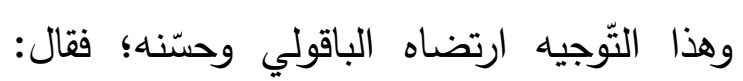

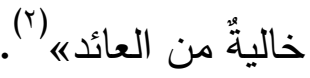

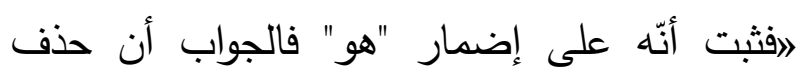
"هو" في الآية سائخ لطول الكلام، وطول الكلام يحتمل معهه ما لا يحتمل مع غيره، ألا ترى أنّهم

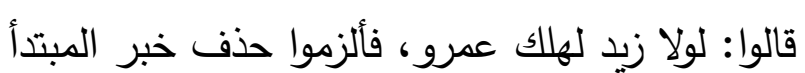
في هذا الباب لطول الكلامه (·).

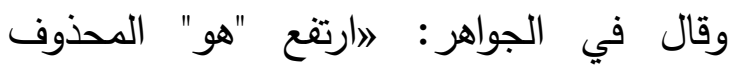
بالابتداء، و"إله" خبره، والظّرف الذي هو قوله: "في

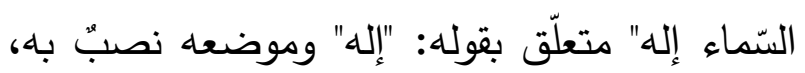

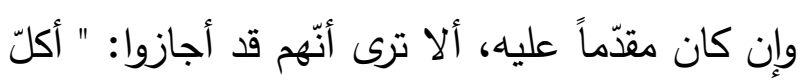
يوم لك ثوبِ"؟ فأُعْمِل فيه المعنى مقدّماً. ولا يصح أن يكون خبر المبتدأ المحذوف قولهي:

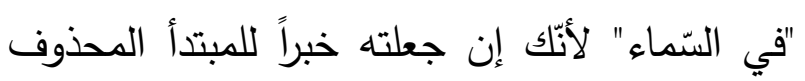
صار فيه ضميره، وارتفع به، وبقي قوله: "إله" مُعلقاً مُفْرداً.

ومع هذا فالمعنى إنّما هو على الإخبار

$$
\text { بالإلاهية لا عن الكون في السّماءه "(') }
$$

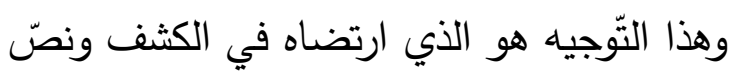

$$
\text { عليه في بدء توجيهه للآية (r'). }
$$

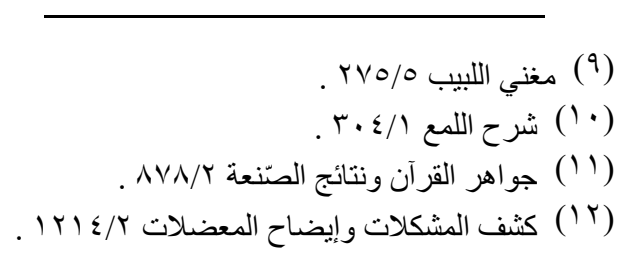

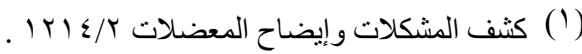

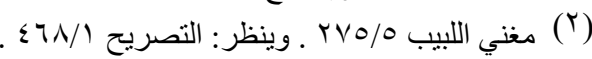

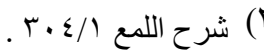

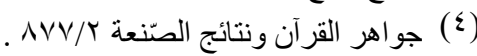

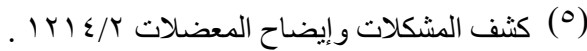

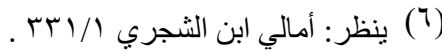

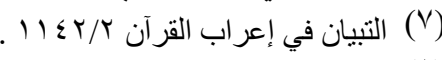

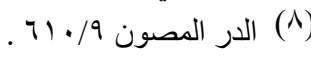




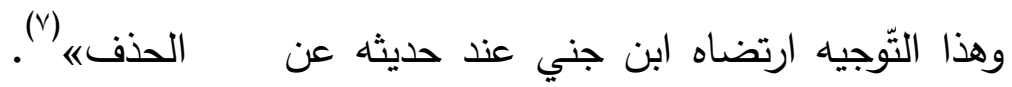

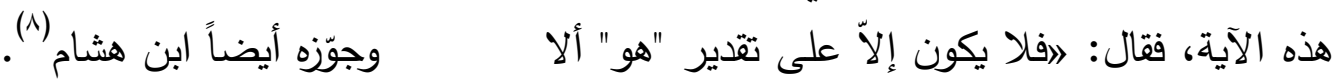

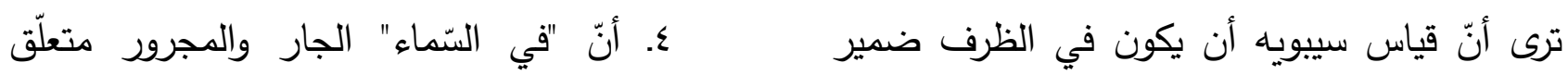

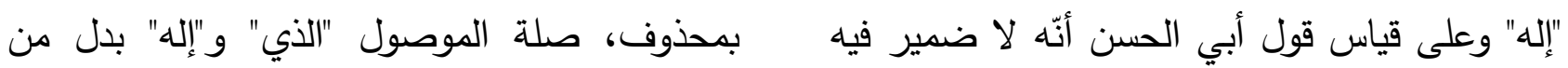
الموصول بصلته، ويكون التّقدير : وهو إلّهّ. وأجاز الباقولي هذا التّوجيه إلانئه أنّه يستحسن ويرجح التوجيه السابق؛ "الثالث"، فقال: "وإن قلت: أحمل قوله "إله" على الضمير الذي في الظرف،

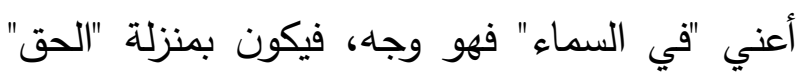

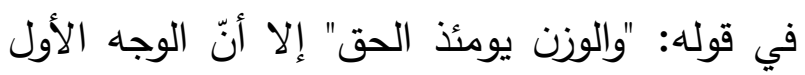

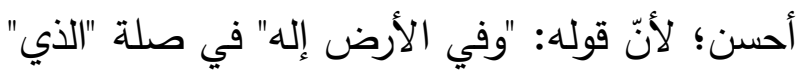
وهو داخل في الصّلة، فلا يبدل عن الضمير؛ لألنّ الأن البدل يجيء بعد تمام الموصوله (9) دأ.

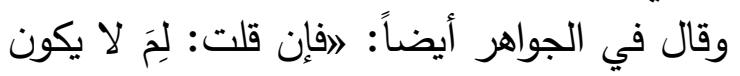

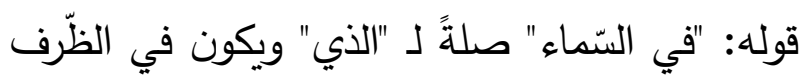
ضمير الموصول، ويكون "إله" بدلاً من الموصول فيكون فئل بصلته، فيكون التقدير : وهو إلمّه.

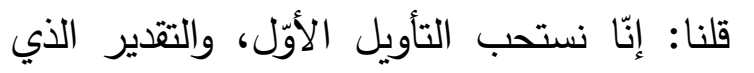

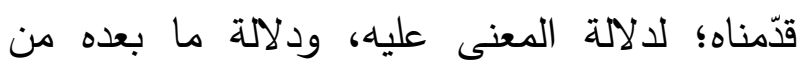
الكلام على ذلك أيضاً. ألا ترى أنّ ما بعده "وفي الأرض إلها. فإِّنما الإخبار عن قصده ـ تبارك اسمه ـ بالعبادة في السّماء

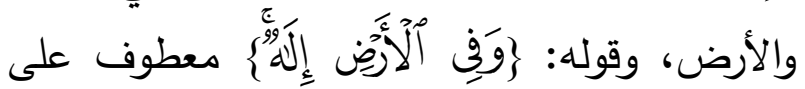
لرفعه "إله" فُتُعرّى الصّلةُُ لذلك من ضمير الموصول،

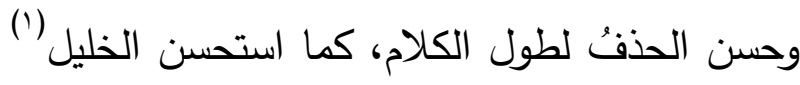
"ما أنا بالذي قائل لك شيئًا" للطوله (؟). وهذا التوجيه نصّ عليه الواحدي ونسبه إلى أبي علي الفارسي (r). ورجّح هذا التوجيه ابن الشجري في أماليه(؛)؛

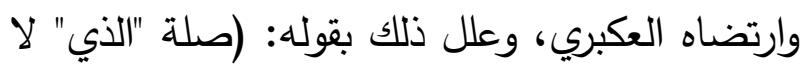
تكون إلا جملة، والتقدير هنا: وهو الذي هو إله في

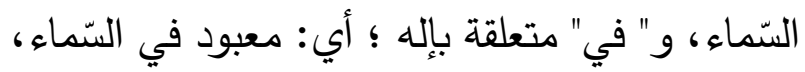

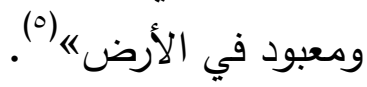
وهذا التّوجيه جوّزه أبو حيّان، فقال أبو حيّان: "وحسّنه طوله بالعطف عليه، كما حسن في: قائل لك شئياً طوله بالمعموله" (؟). وجوّزه أيضاً السمين الحلبي، وعقب لبع على كلام شيخ أبي حيان فقال: ارقلت: حصوله في الآية وفيما حكاه سواءٌ؛ فإنّ الصّلة طالت بالمعمول في كليهما، والعطف أمر زائدٌ على ذلك، فهو زيادة في تحسين

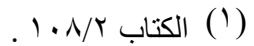

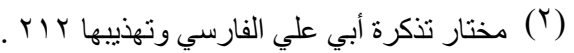

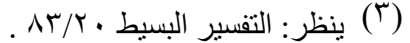

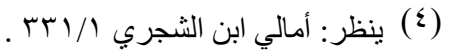

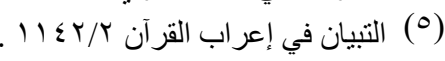

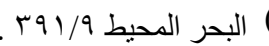


كذلك؛ لتضمّنه الإبدال من ضمير العائد مرتين،

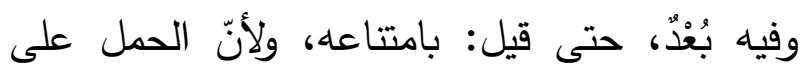

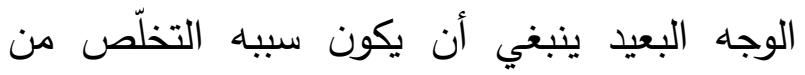

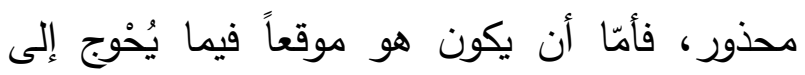

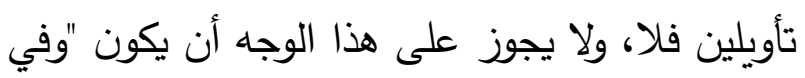

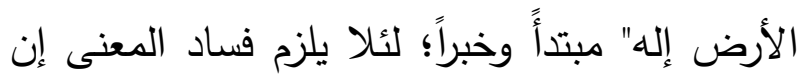

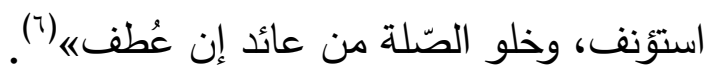

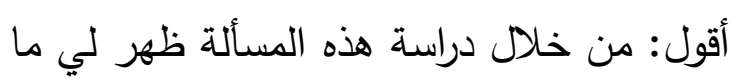

يأتي:

ا. أنّ ما ذكره الباقولي من توجيهات في هذه الآية مأخوذ من أبي علي الفارسي الذي نصّ على على نواته

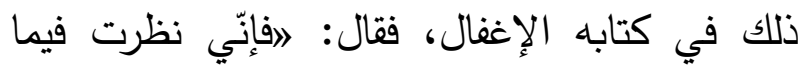
يرتفع به "إله" فوجدت ارتفاعه يصح بأن يكون

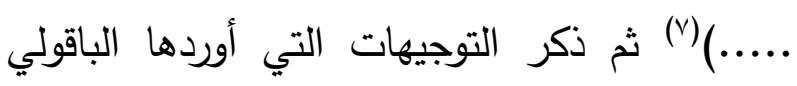
نقلاً عنه، وقد أشار إلى ذلك الدكتور محمد أحمد الدالي في حواشيه المذكورة في كتب الباقولي التي

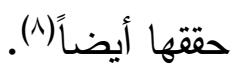

r. أنّ الباقولي صرّح في كتابه الجواهر باعتراضه على التقسيم الذي ذكره أبو علي الفارسي،

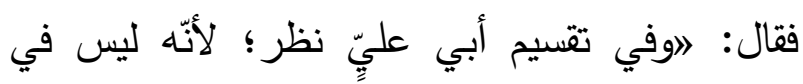
القسمة ارتفاع "إله" بالابتداء؛ لأنّ الظرف جرى لفَ صلةً لموصول، فليس إلا أن يقول: إنّ ارتفاع "إله" لا لانئل

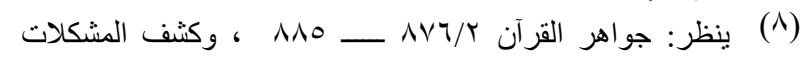
(T) 10 (1) $1 \leqslant / 4$
الصّلة، فلا يجوز أن يبدل "إله" من الموصول، وقد

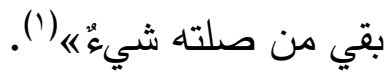
وقال في الكشف: إفان قلت: فاجعل في الظّرف

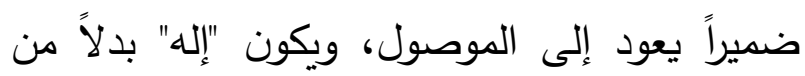
ذلك الضمير فذلك جائز ه(؟). وجوّز العكبري هذا الوجه لكن بضعف؛ فقال:

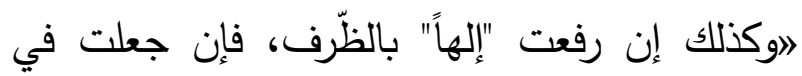
الظّرف ضميراً يرجع على الذي، وأبدلت إلهاً منه جاز على ضعف؛ لأنّ الغرض الكلي إثبات إلهيته

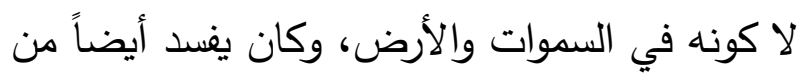

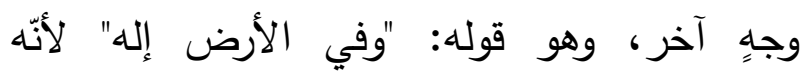

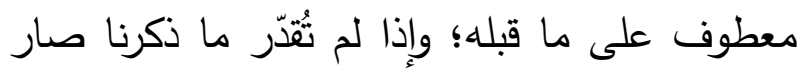
منقطعاً عنه، وكان المعنى إنّ في الأرض إلهاً ().

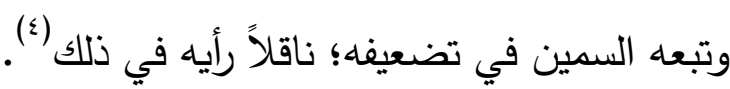

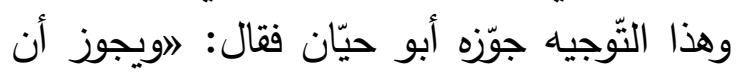
تكون الصّلة الجار والمجرور، والمعنى: أنّه فيهما

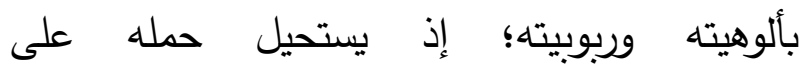
الاستقرار 《(0). وهذا التّوجيه لم يستحسنه ابن هشام فقال: اولال

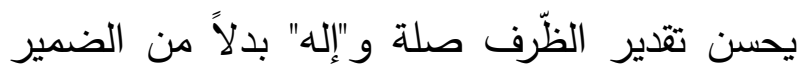
المستتر فيه، وتقدير: "وفي الأرض إله" معطوفاً

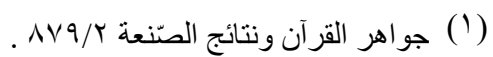

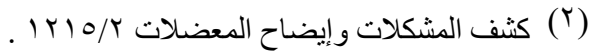

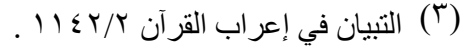

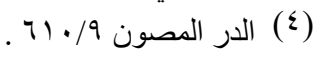

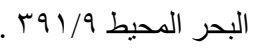




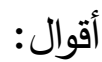

القول الأوّل: إنّها تعمل عمل ليس؛ فترفع الاسم

وتتصب الخبر، وهذا مذهب جمهور النّحاة(؟).

وتعمل بشرطين: كون معموليها اسمي زمان،

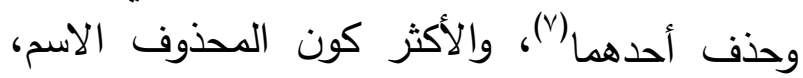

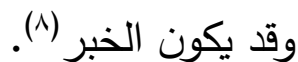

لكنهم اختلفوا في عملها حينئذٍ:

1. فمنهم من يرى أنها تعمل في لفظ الحئ الحين

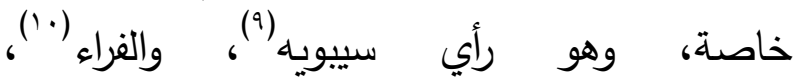

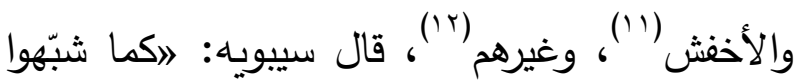
بها (rا') لات في بعض الأ وغيرم المواضع، وذلك مع الحين

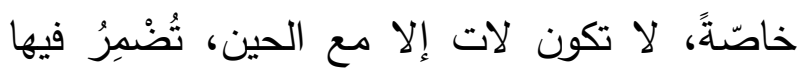

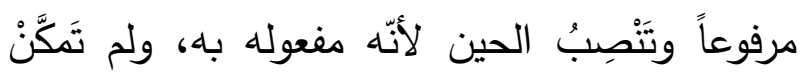

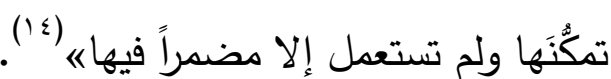

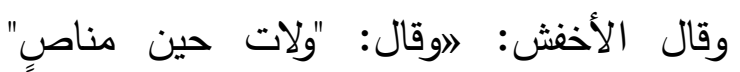
فشبهوا "لات" بـ "ليس" وأضمروا فيها اسم الفاعل، ولان

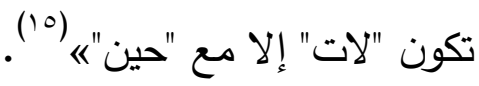

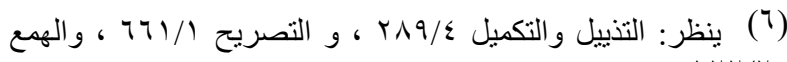
. ITY/T

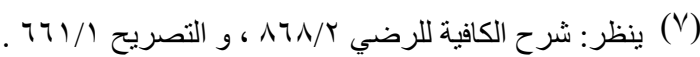

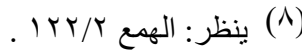

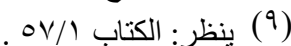

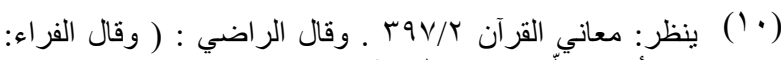

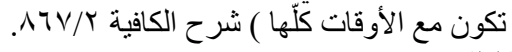

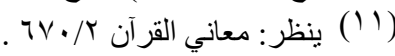

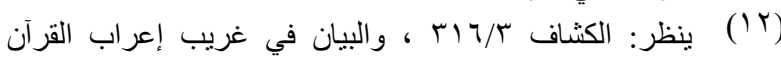

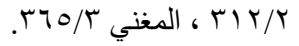

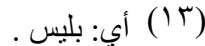

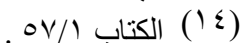

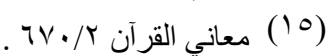

يخلو من أن يكون بإضمار "هو" أو بالظّرفه|") r. أنّ الباقولي لم يصرّح بنسبة الرأي إلى لى لإنى

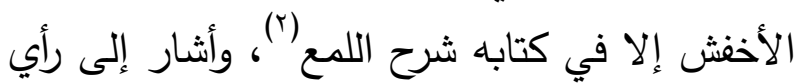
الأخفش ابن جني في كتابه مختار تذكرة أبي علي (ז). ( ) ع. الترّجح في هذه المسألة هو القول الثّالث؛ وهو الذي رجّحه الباقولي وحسّنه؛ لقوّة الأدلة التي لهولي ذكرها العلماء الذين أجازوا هذا القول، وبالله

\section{雾}

المبحث الثالث: إعمال "لات".

قال الباقولي: لاوالمرتبة الرابعة مرتبة "لات" تأنيث لا، كما أنّ "ربت" تأنيث ربّ، و "ثثت" تأنيث ثم، ولا تعمل لات في شيء إلا في حين، قال الله

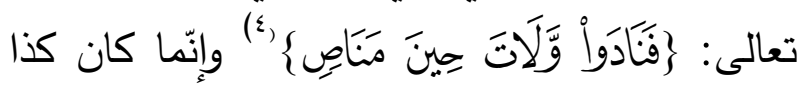

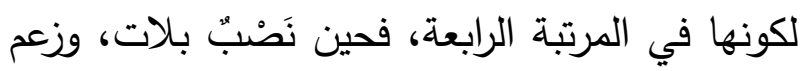

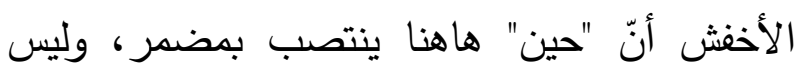

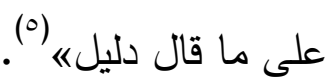

\section{策}

اختلف النّحاة في "لات" هل لها عمل أم لا؟ والذين قالوا إنها تعمل اختلفوا في ذلك، على عدة

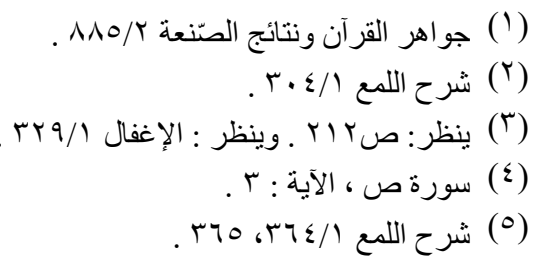


r. ومنهم من أجاز ذلك في الحين وما رادفه ك واختاره أبو حيّان(9).

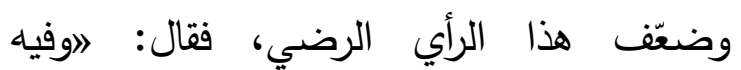

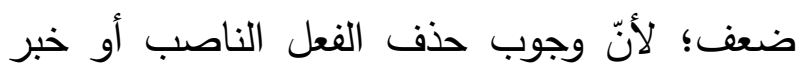

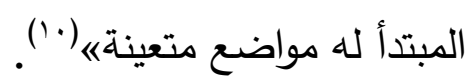
وقال أبو حيّان: لاوما ذهب إليه الأخفش من له

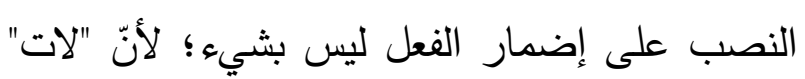

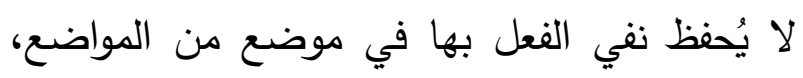

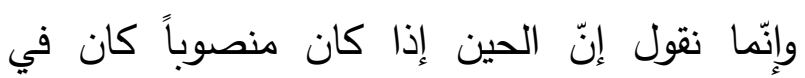

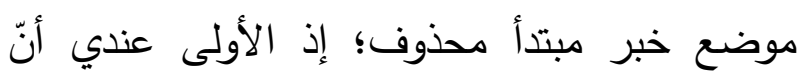

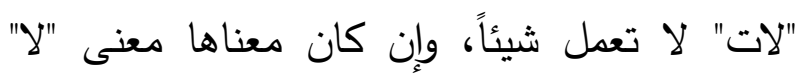

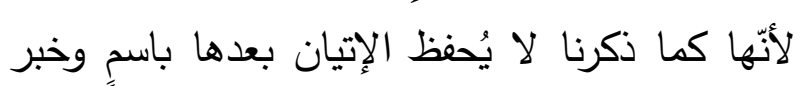
مثبتينه (')

القول الثالث: أنّ "لات" هي "لا" النافية للجنس،

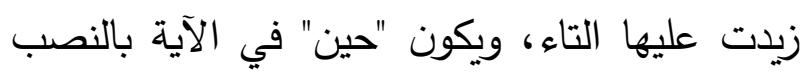

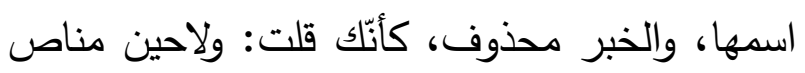
لهم.

وهذا الرأي منسوب إلى الكوفيين والأخفش(rا). وعلل ابن الحاجب ذلك بقوله: اوأمّا وجه قول من زعم أنّها لنفي الجنس فلأنّها الكثيرة في واني

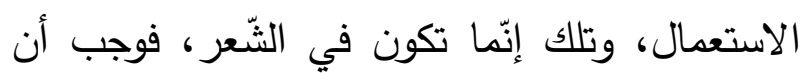
يُحمل القرآن على الوجه الفصيحها" (r).

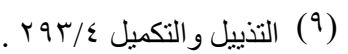

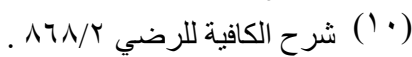

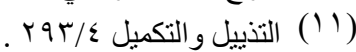

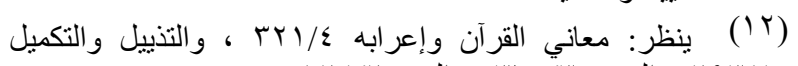

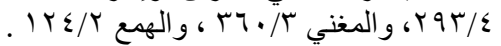

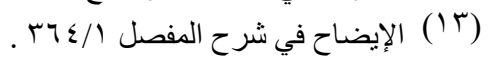
"أوان، وساعة" وسواء أكان معرفة أم نكرة، وهو رأي

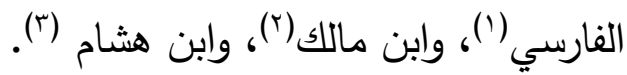

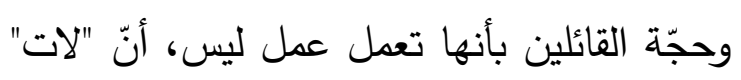
دخلت عليه تاء التأنيث، وهي من خواصهاص الفعل،

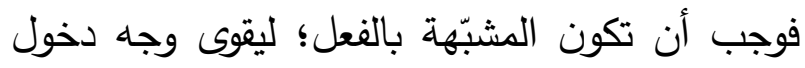
التاء (ई). وقال الرضي: اوتعمل عمل ليس لمشابهتها له،

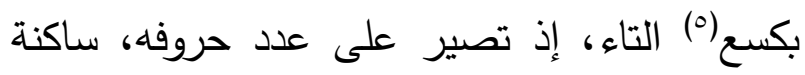

الوسطه (7).

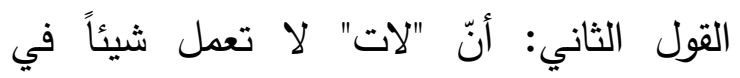
القياس؛ لأنّها ليست بفعل، بل الاسم الذي بعدها إن

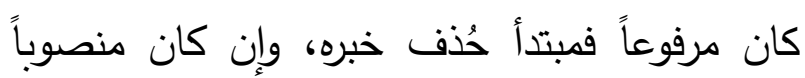

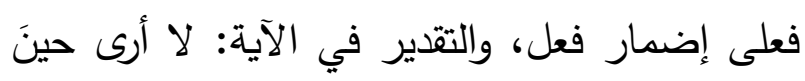

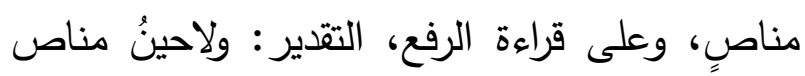

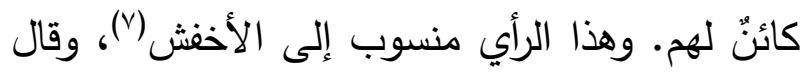

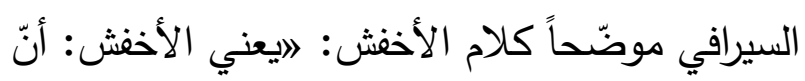
"لات" حرف غير عامل، فإذا كان ما بعدها مرفوعاً

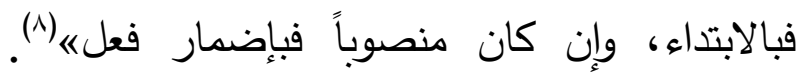

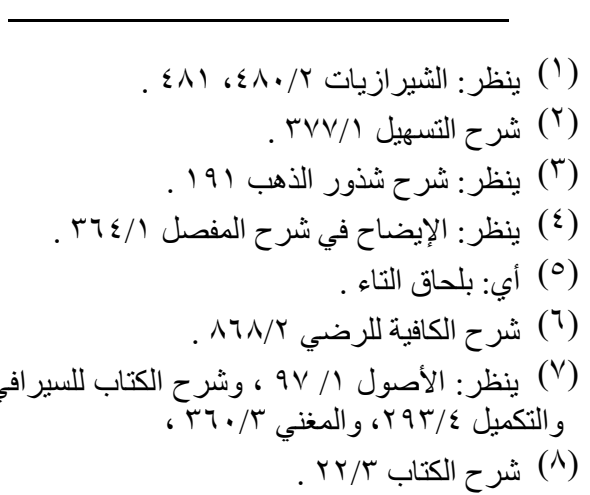


قال الباقولي: 》الواو في قولك: قمتُ وزيداً،

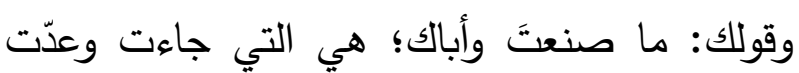

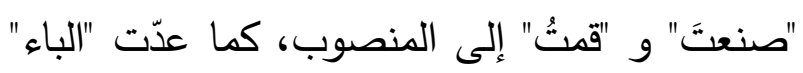

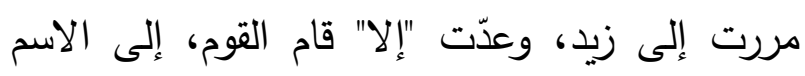

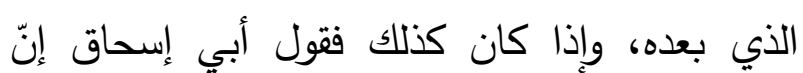

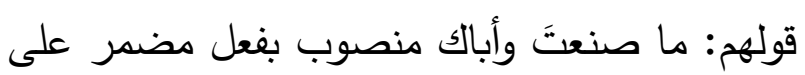

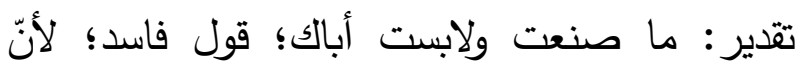

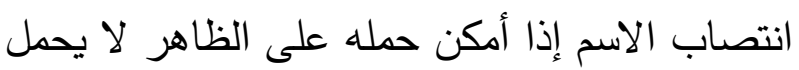

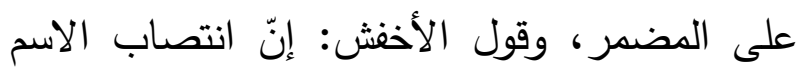

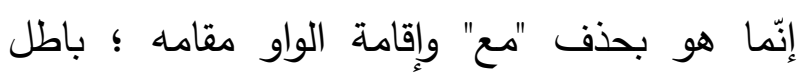
بقوله: كل رجل وضيعته، وأنت أعلم ومالك، فإِّ هذه هو

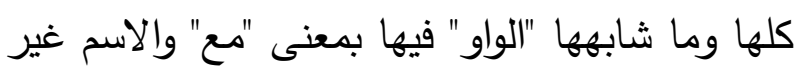
منصوب، فثبت قول سيبويه؛ وأنّ الاسم منصوب بالفعل الواقع قبله بتقوية الواوه (ء).

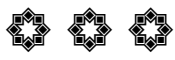

اختلف النحاة في عامل النّصب في المفعول

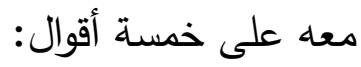
القول الأوّل: أنّ العامل في المفعول معه هو الفعل الذي قبله بتوسّط الواو؛ لأنّ الفعل فُوّيّي بالواو

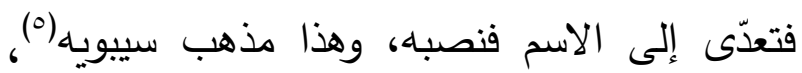

$$
\text { وجمهور النّحاة(؟). }
$$

القول الثاني: أنّه ينتصب انتصاب الظرف؛ لأنّ

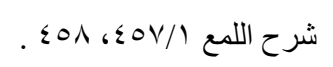

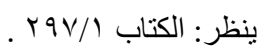

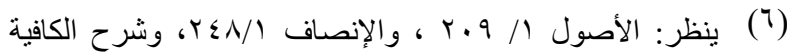

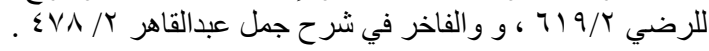

القول الرابع: أنّ "لات" تعمل عمل "إنَّ" فتتصب الاسم وترفع الخبر، وهذا الرأي منسوب إلى لإنى

الأخفش (').

ومن خلال دراسة هذه المسألة يظهر جليّاً أنّ الأن

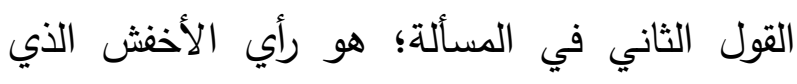
أثار إليه الباقولي بقوله: "اوزعم الأخفش أنّ "حين" الآل هاهنا ينتصب بمضمر، وليس على ما قال دليله" (r). وما ذهب إليه الأخفش واختاره أبو حيّان من كونها غير عاملة محكوم عليه بالضعف؛ لأنّ النّا وجوب حذف الفعل الناصب، أو خبر المبتدأ له له مواضع متعينة بإجماع النحويين ليس منها ذلك.

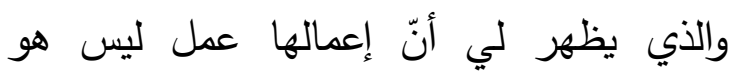
الكثير المشهور، وهو ما عليه سيبويه والجمهور؛

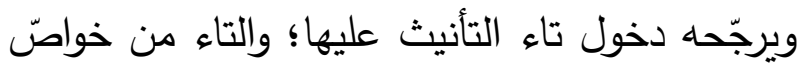
الأفعال (").

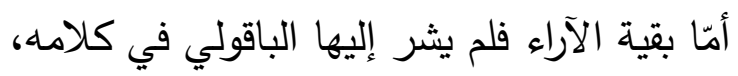

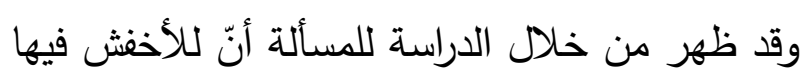
ثلاثة أقوال. وبالله التَّفيق.

\section{$\$$}

المبحث الزّابع: عامل النصب في المفعول معه.

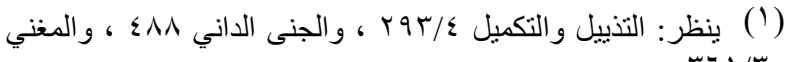

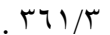

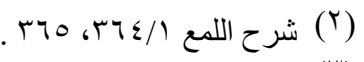

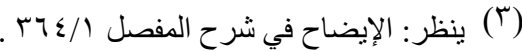


ولابس الخشبة، وهذا منسوب إلى الزّجاج(§).

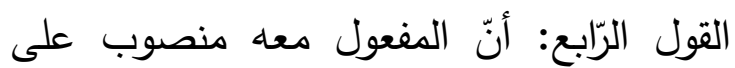

الخلاف، وهو مذهب بعض الكوفيين(0). القول الخامس: أنّ العامل في المفعول معه هو الواو، وهذا مذهب الجرجاني (†). وعند مناقشة هذه الأقوال نجد أنّ الباقولي لم لم لجابل

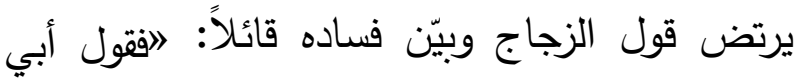
إسحاق إنّ قولهم: ما صنعتَ وأباك منصوب بفعل مضمر على تقدير: ما صنعت ولابَسْتَ أباك؛ قول فال

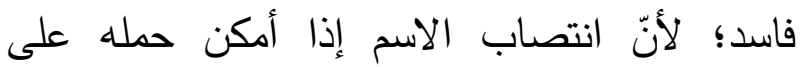

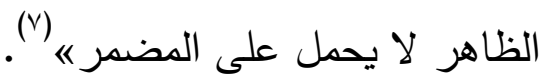
وبيّن ابن مالكك أيضاً فساد قول الزجاج؛ فقال: اوممّا يبين فساد تقدير الزّجاج أنّه إمّا أن يُّتصد تشريك صنعت ولابست في الاستفهام، وإمّا ألا

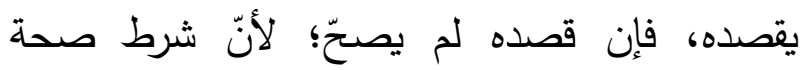

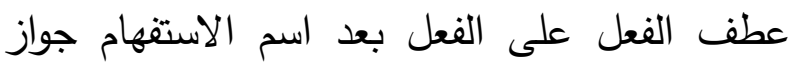

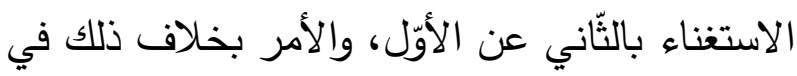

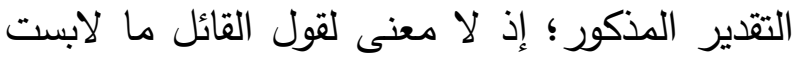

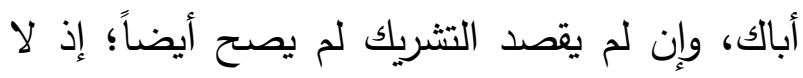

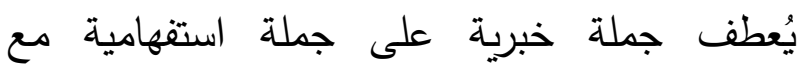

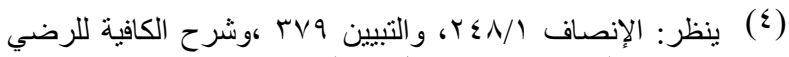

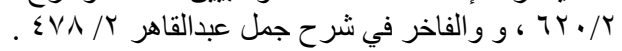

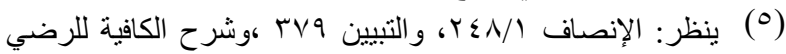

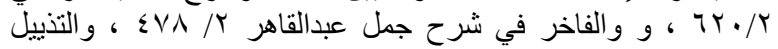
و التكميل

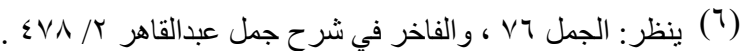

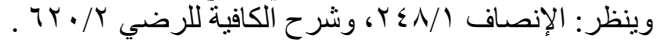
شرح اللمع (V) (V)
الواو واقعة موقع "مع" وهذا مذهب الأخفش('). ونسبه أبو حيّان إلى معظم الكوفيين والأخفش(؟). وبيّن ابن جنّي رأي الأخفش ووضحه بقوله: اوعلى

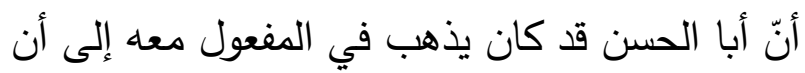
انتصابه انتصاب الظرف، قال: وذلك أنّ الواو في

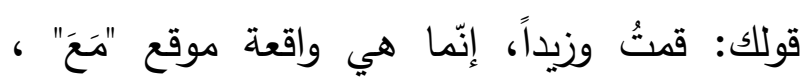

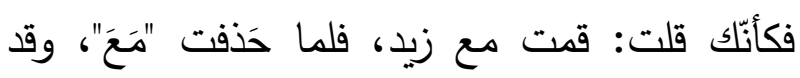
كانت منتصبة على الظّرف، ثم أقدت الواو مقامها انتصب "زيد" بعدها على معنى انتصاب "تَعَ" الواقعة

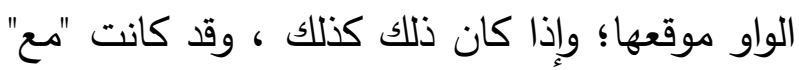
منصوبة بنفس "قمت" بلا واسطة، فكذلك يكون

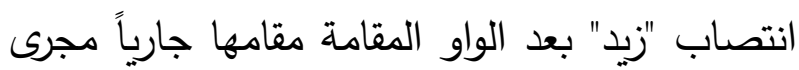
انتصاب الظروف، والظروف مما يتاولها "قمت" بلا واسطة حرف، فكأنّ الواو الآن على مذهب أبي

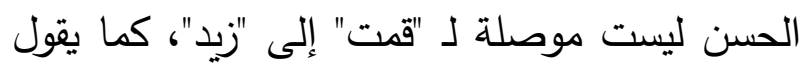

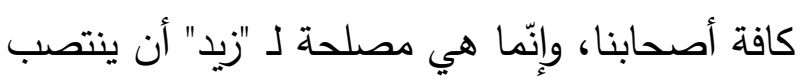
بتوسطها انتصاب الظرف، وليست مُوصّلة للفعل إلى ما بعده إيصال حروف الجر الأفعالَ قبلها إلى

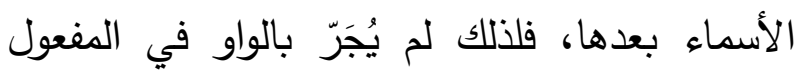
(r) "(r) القول الثّالث: أنّ المفعول معه منصوب بفعل محذوف، ففي قولهم: استوى الماءُ والخشبة، التقدير :

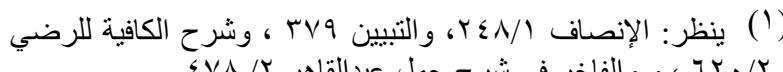

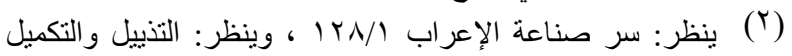


لأنّ قولك: استوى الماء والخشبة، وسرتُ والنيل،

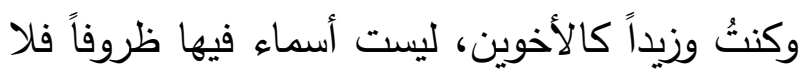
تتتصب انتصابهاه (०). ولم يرتضه الرضي وعلل ذلك بكلام مشابهٍ لما

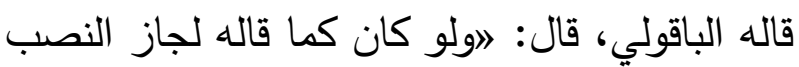

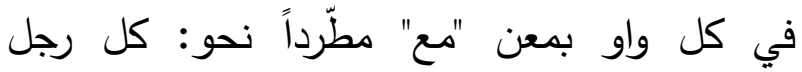
وضيعته (1)

وأبطل أبو حيّان رأي الأخفش أيضاً، فقال:

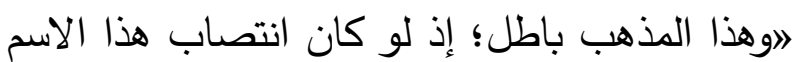

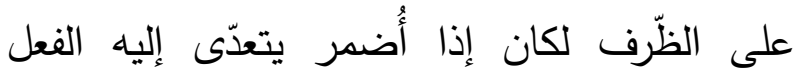
بوساطة في، وأنت لاتأتي به إلا منفصلاً، نحو قوله:

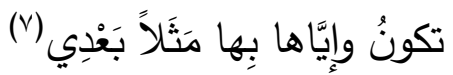

$$
\text { ولم يقل: تكون فيهاه (^). }
$$

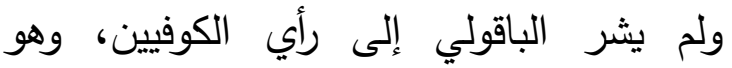
النّصب بالخلاف، لكنّ هذا الرأي أبطله ابن مالك لكائ

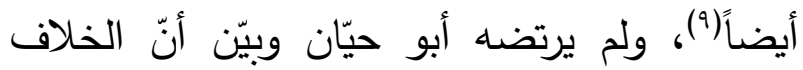

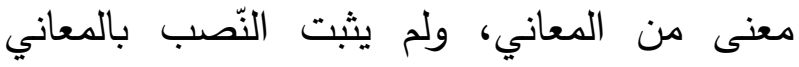
المجردة من الألفاظ، وأيضاً لو كان الخلاف ناصباً

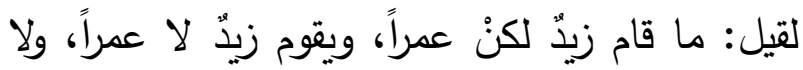

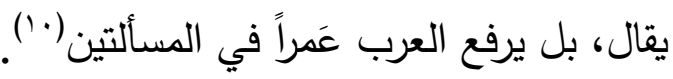

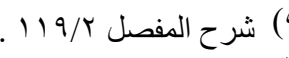

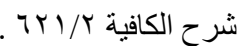

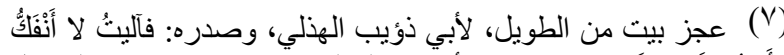

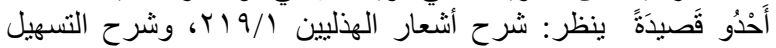

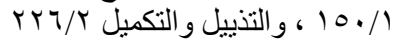

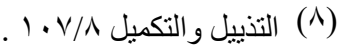

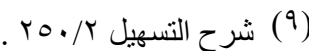

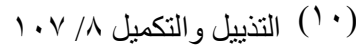

استقلال كل واحدة منهما، فألايجوز ذلك مع

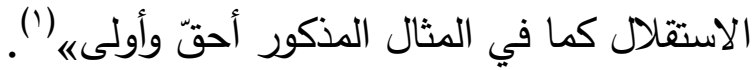

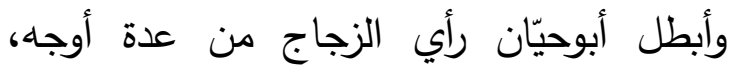
فقال: اروما ذهب إليه باطل؛ لأنّ في نصب الاجن الاسم بفعل مضمر إحالة لباب المفعول معه؛ إذ يصير منصوباً على أنّه مفعول به لا مفعول معه. وأيضاً

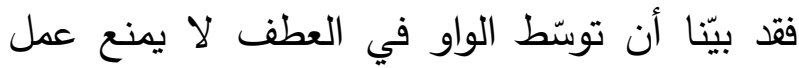

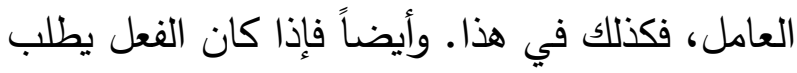
المفعول على معنئ يقتضي توسّط حرف بينهما

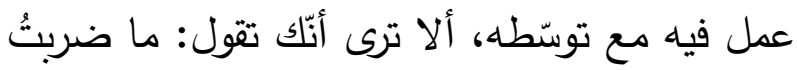
إلا زيداً، فتتصب زيداً بتوسّط إلا، ولم تُبال بهذا لتها الفصل؛ لأنّ المعنى يقتضيه، وكذلك الفصل بـ "إمّا"

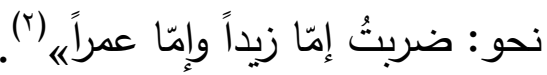
وتعقّب الباقولي رأي الأخفش وأبطله، فُّال: "وقول الأخفش: إنّ انتصاب الاسم إنّما هو بحذف لراي "مع" وإقامة الواو مقامه؛ باطل بقوله: كل رجل

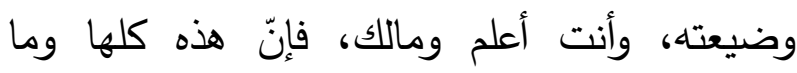

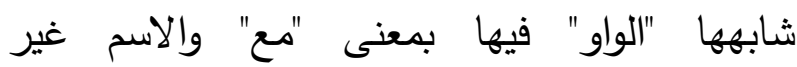
منصوب " (r) وضعَفه أبو البركات الأنباري(؛)؛ وابن يعيش،

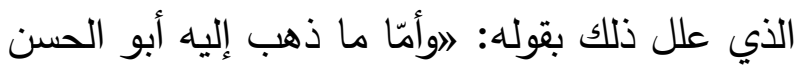

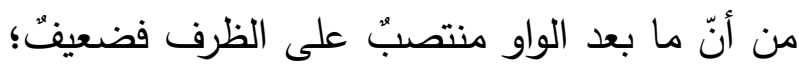


والرأي الراجح في هذه المسالة؛ هو القول الأوّل،

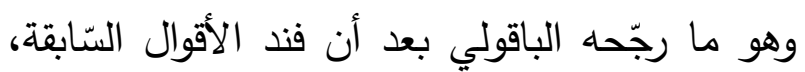

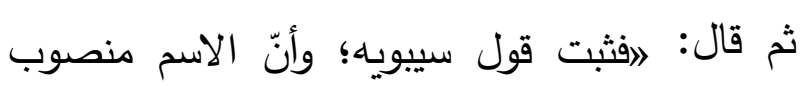

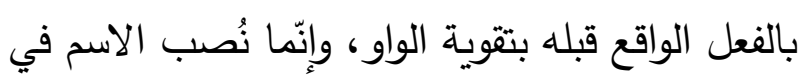

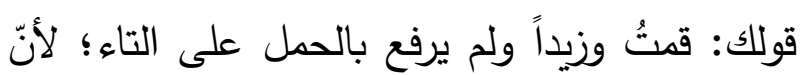
التاء فاعل وقد جرى من الفعل مجرى أحد أجزائه فلم

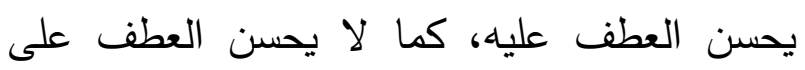

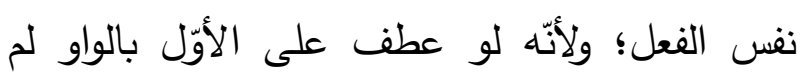

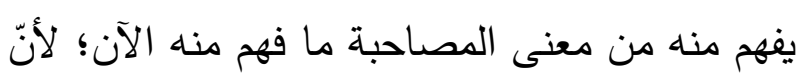
الواو للشركة والجمع دون التِران، فقولك: قمت وزيداً يراد منه المصاحبة والقران، وكذلك: جاء البرد والطيالسة، يراد القران والمصاحبة دون محضية الجمع، وقولهم: استوى الماء والخشبة يراد منهما

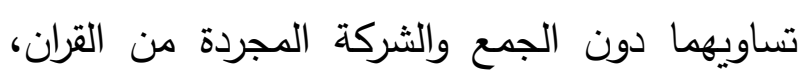
وكذلك: مازلت أسيبر والنيل على هذاه("). وهو الرأي الذي رجحه ابن مالك، فقال: الإذاذا بطلت الأقوال الثلاثة تعيّن الحكم بالقول الأول؛ وهو التح

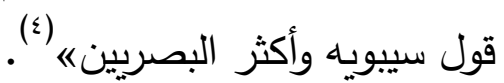

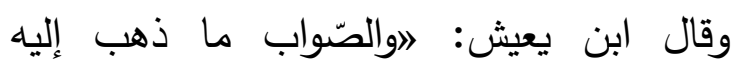

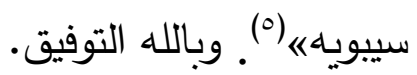

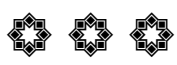

المبحث الخامس: العطف على معمولي

عاملين.
ولم يشر الباقولي أيضاً إلى رأي الجرجاني، لكن ابن مالك أبطله من ثلاثة أوجه؛ هي ('):

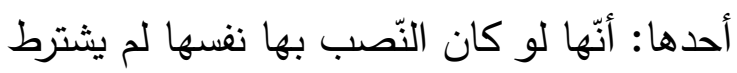

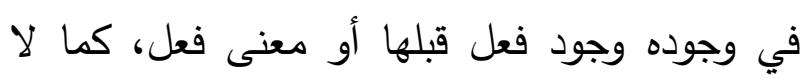

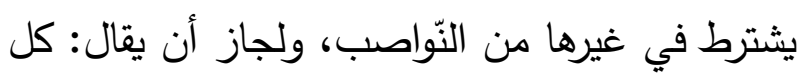

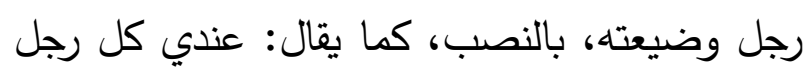
وضيعته.

الثّاني: أن الحكم بكون الواو ناصبة حكم بما لا

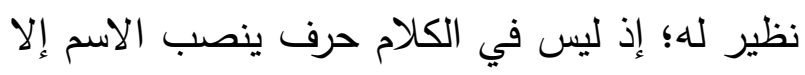

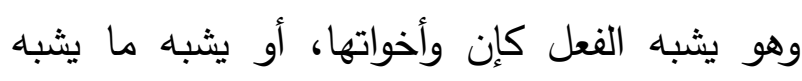

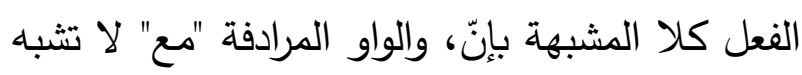
الفعل ولا ما أشبه الفعل، فلا يصح جعلها ناصبة للاسم.

الثّالث: أنّها لو كانت هي النّاصبة لوجب

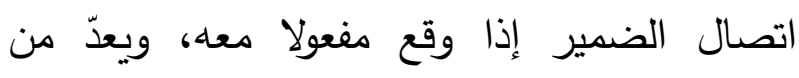
الضرورات قول الثاعر : الضمير فآليت لا أنفكُُ أحذو قصيدة

تكونُ وإيّا ها بها مثلا بعدي

ولا خلاف في وجوب الانفصال في مثل هذا، فُعُلم بذلك أنّ الواو غير عاملة؛ إذ ليس في الكلام ضمير نصب يجب انفصاله مع مباشرة النّاصب.

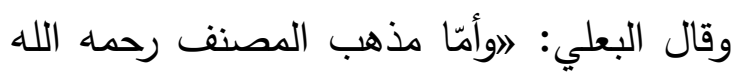

تعالى فضعيفت جدّاً (r).

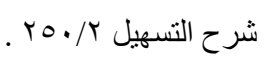

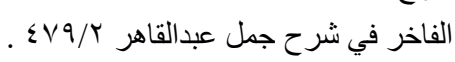


كالمنصوبين أو المرفوعين على معمولَي عاملين مختلفين، نحو: إنَّ زيداً ضرب العرعين عمراً وبكراً خالداً، فهذا عطف متفقيَي الإعراب على معمولي عاملين مختلفين.

وقولك: إنّ زيداً ضربَ غلامَهُ وبكراً أخوه؛ عطفُ مختلفي الإعراب.

ولا يعطف المعمولان على عاملين بل على معموليهما، فهذا القول منهم على حذف المضاف. وذكر ابن عصفور الأمثلة وفصّل فيها، فقال: "ويجوز أن تعطف بحرف العطف اسماً فصاعداً على اسم مثله فصاعداً، فتقول: ضرب زيدّ عمراً وبكرّ خالداً، فتعطف بالواو بكراً وخالداً على زيد وعمرو. وتقول: ظَنَّ زيدّ عمراً منظلقاً وبكرُ جعفراً مُقيماً، فتعطف بالواو بكراً وجعفراً ومقيماً على زيد

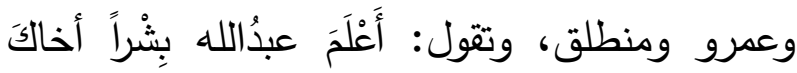

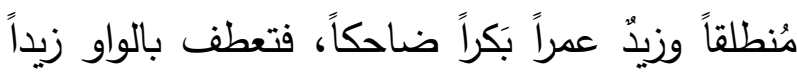
وعمراً وبكراً وضاحكاً على عبدالله وبشر وأخيك ومنطلقِ. وكل ذلك جائز ما لم يؤدّ إلى العطف على والى والى

عاملينه (r).

وقد اختلف النّحاة في هذه المسألة على خمسة

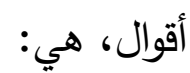

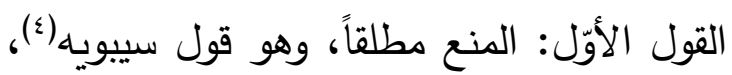

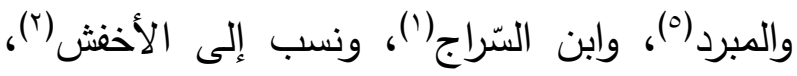

قال الباقولي: 》فأمّا قولهم: ليس زيد بقائم ولا قاعٍٍ عمرو إنّما لم يجز بالجرّ لأنكا تجر قاعداً بالعطف على قائم، وترفع عمراً بالعطف على زيد لئ فيكون ذلك عطفاً على عاملين، أحدهما: ليس، والآخر: الباء، وسيبويه منع من ذلكانك، وأجازه الأخفش، وقال: لو قلت مررت بزيد في الدار والقصر عمرو جاز أن تعطف القصر على المجرور بفي وتعطف عمراً على المجرور بالباء وأخذ يحتج النج لذلك بأثياء... والأمر بخلاف ما زعم أبو الحسن، وذلك لأئه لو جاز العطف على عاملين لجاء لجاز

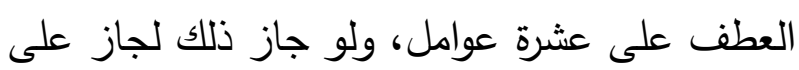
مائتين وأكثر من ذلك، وهذا بيّن الفساد؛ لأنّ حرف هانَ

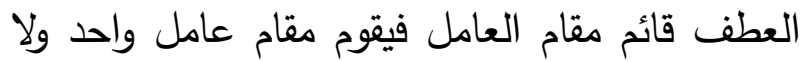

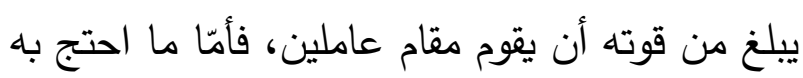
من الآي والأبيات فإنما جاز إضمار أحدان العانيان العاملين

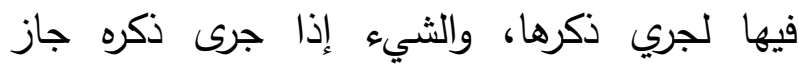
إضماره ضرورة تصحيح اللفظ والكلامه" (1).

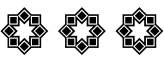

يجدر بنا قبل البدء في عرض أقوال العلماء في المسألة أن نعرض لـعناها، وأمثلتها؛ فمعنى قولهم:

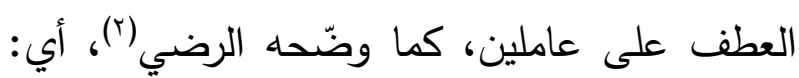

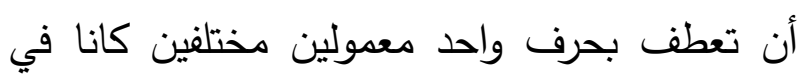

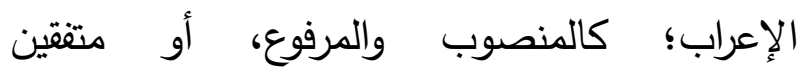

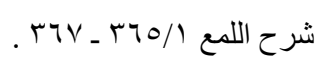

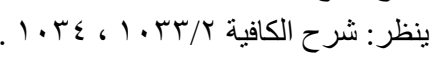


القول الثاني: الجواز مطلقاً، وهو مذهب

وصححه ابن مالك (r).

الأخفش (v).

القول الثالث: لابدّ في العطف على عاملين من أن يكون أحدهما جارًاً، وإذا كان أحدهما مجروراً

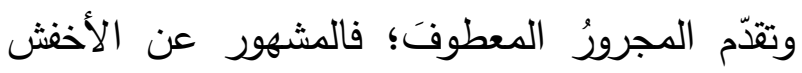

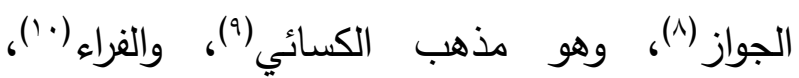
والزجاج(')، وتبعهم أبو جعفر بن مضاء، وأبو بكر

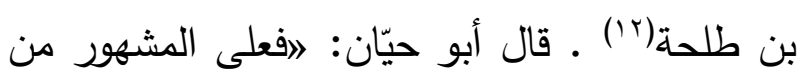
مذهب الأخفش ومَن تبعه يجوز ذلك، وسواء أكان

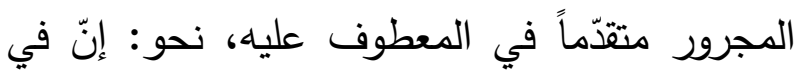
الدار زيداً والحجرة عَراً، أم متأخراً، نحو: إنّ زيداً

$$
\text { في الدّار والحجرة عَراًَ('ان). }
$$

ورأي الأخفش هذا هو ما نصّ عليه الباقولي واستدلّ له، فقال: إفمّا قولهم: ليس زيد بقائم ولا قاعدٍ عمرو إنّما لم يجز بالجرّ لأنّاك تجر قاعداً

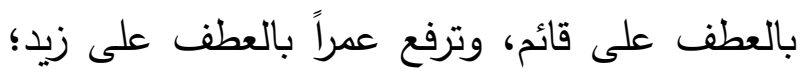

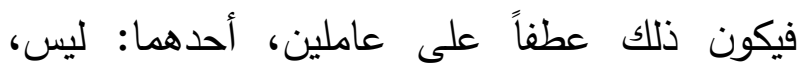
والآخر: الباء، وسيبويه منع من ذلكة دلك، وأجازه

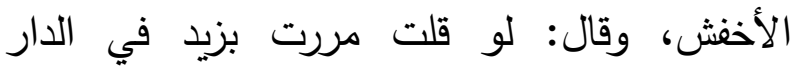
والقصر عمرو جاز أن تعطف القصر على المجرور

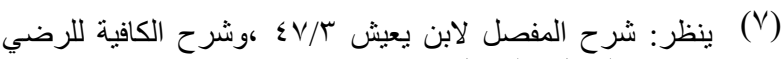

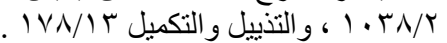

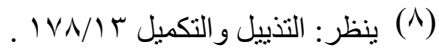

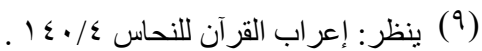

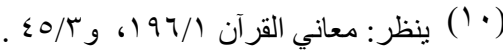

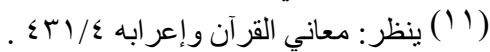

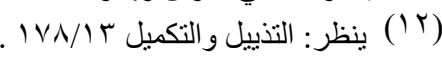

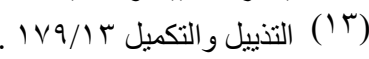

\section{وحجتهم في ذلك: أنّ حرف العطف ضعيفت فلا}

يقوى أن ينوبَ منابَ عاملين، ويدلَّ في حالٍ واحدةٍ

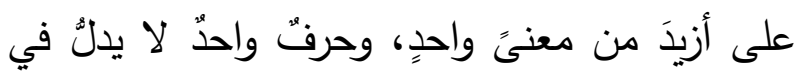

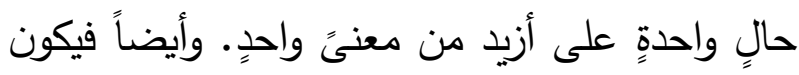

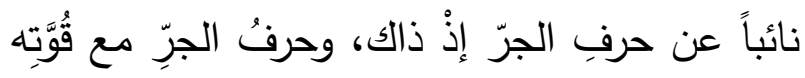

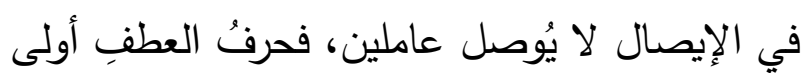

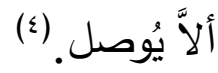

وقال ابن السّراج: إفالعطف على عاملين خطأ في القياس، غير مسموع من العرب، ولو جاز العطف على عاملين لجاز على ثلاثة وأكثر من ون ذلكي (0) وهذا القول ذهب إليه الباقولي فقال: اروالأمر بخلاف ما زعم أبو الحسن، وذلك لأنّه لو جاز العطف على عاملين لجاز العطف على عشرة زوامل، ولو جاز ذلك لجاز على مائتين وأكثر من ذلك، وهذا بيّن الفساد؛ لأنّ حرف العطف قائم مقام العامل فيقوم مقام عامل واحد ولا يبلغ من قوته أن يقوم مقام عاملين" (`).

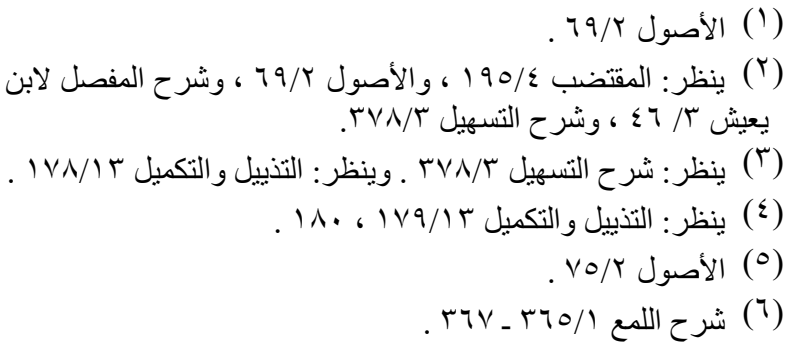




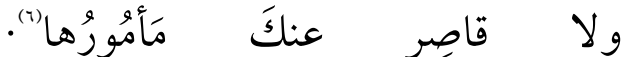

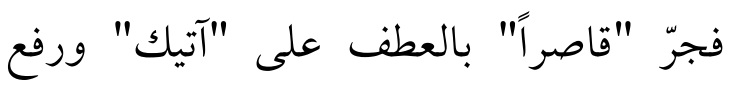

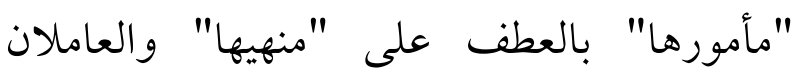

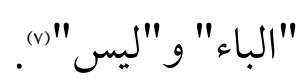$$
\text { ع-وقال الفرزدق: }
$$

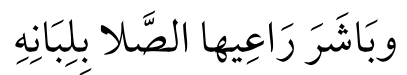

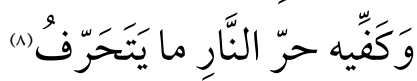

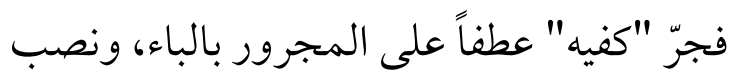

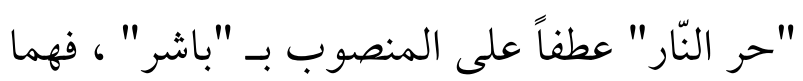
عاملان مختلفان (9). قال عن هذه الثواهد أبو حيّان: الاومن أجاز ذلك مطلقاً قاسَ غيرَ ما فيه جارٌّ على ما فيه جارٌّ.

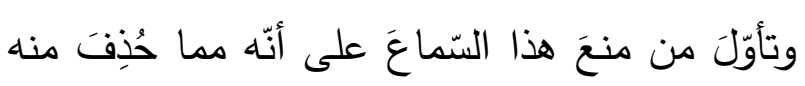
الجارٌ لدلالة ما قبله عليهيه ('). ولم يرتض الباقولي هذه الثواهد، فقال: الفأمّا ما احتج به من الآي والأبيات فإنما جاز إضمار أحد العاملين فيها لجري ذكرها، والثيء إذا جرى ذابه ذكره

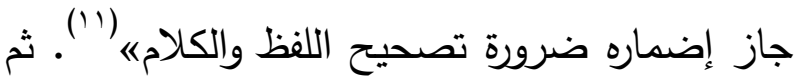
فصّل القول في تلك الثّواهد، وخرّجها بما يتناسب

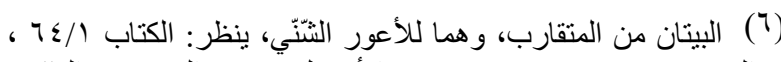

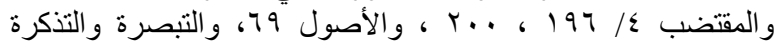

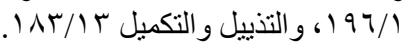

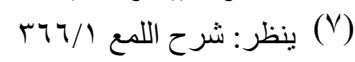

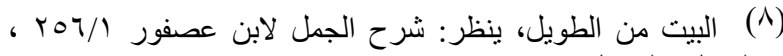

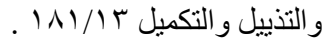

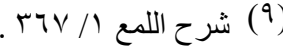

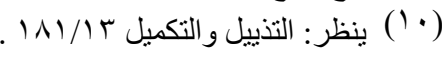

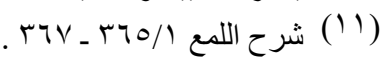

بفي وتعطف عمراً على الدجرور بالباء وأخذ يحتج

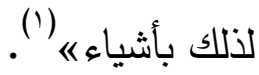
وحجّة المجوّزين السماعُ، من ذلك ما يأتي:

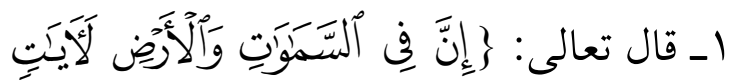

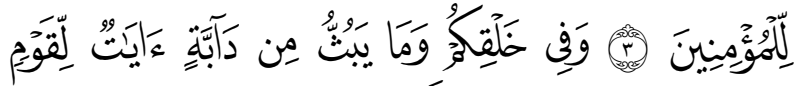

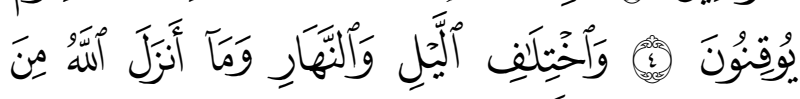

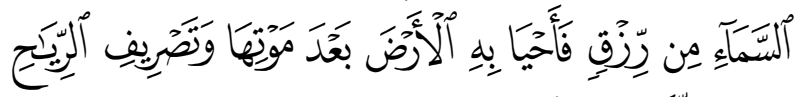

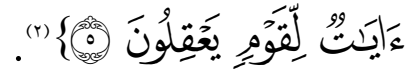

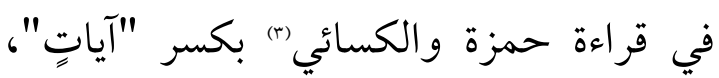

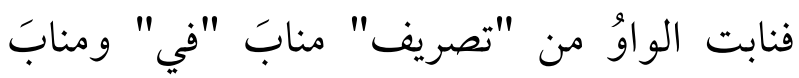

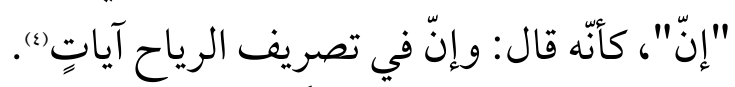

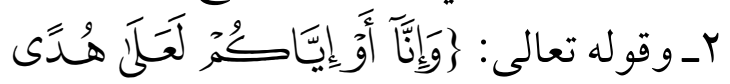

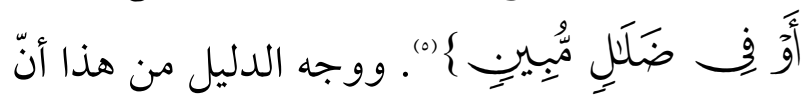

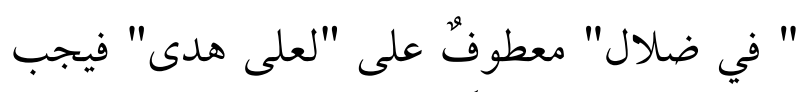

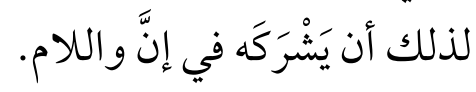

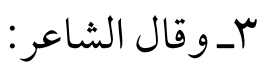

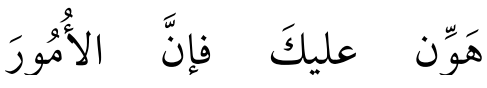

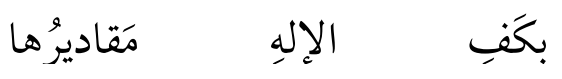

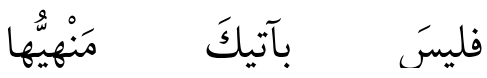

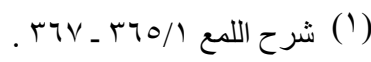

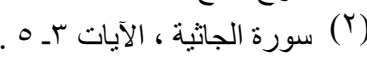

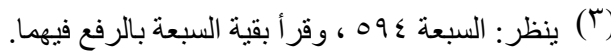

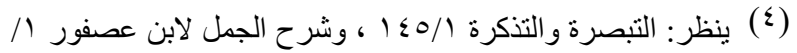

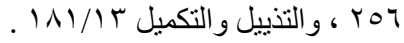

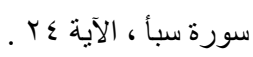


جر "واختلاف" بالعطف على ما عملت فيه "في"

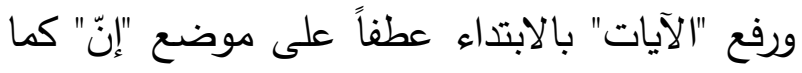

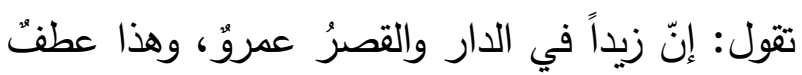
على عاملين أيضاً، وهما: "في" وموضع إنّ الذي إني هو ابتداء (0). وخرّج الآية الثانية على أنّ التقدير في قوله: "أو في ضلال" أو لفي ضلال فأضمر اللام لجري ذكره

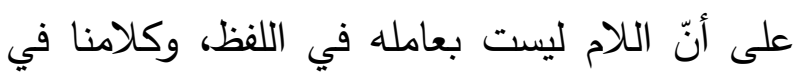
اللفظ لا في المعنى (؟). وخرّج بيت الأعور الثّنّي على أنّ الرواية

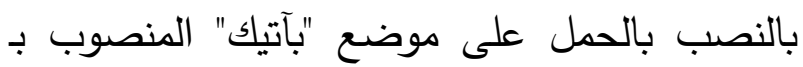
"ليس" ، فهو عطف على "ليس" فحسب، وروي بالرفع على الأيتناف، فأمّا الجر فزعم أنه تصور

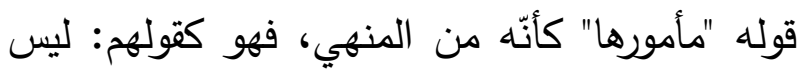

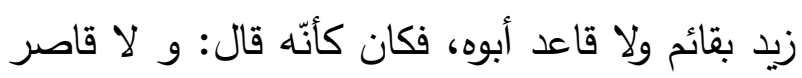

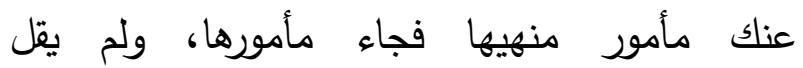

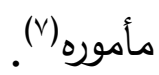

وخرّج بيت الفرزدق على أنّه أضمر الباء فيه

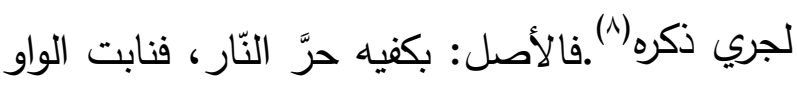
مناب باشَرَ خاصة، فحُذِفت الباءُ ولم ينب منابها حرف العطف (9).

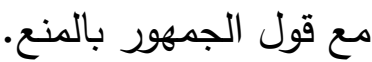
فخرّج الآية الأولى على أنّ التقدير في قوله: "واختلاف الليل" وفي اختلاف الليل، وأضمر "في" الاوكي التئ لأنّ قوله "وفي خلقكم" دلّ على ذلك ('). ونقل الباقولي رأي المبرد (؟) في تخريج الآية، فقال: اوزعم محمد بن يزيد المبرد أنّ الآية محمولة

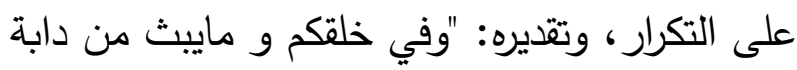
واختلاف الليل والنهار" فهو عطف على السماوات، ولو ذكر هكذا علم منه ما يعلم منها الآن، إلا أنّه

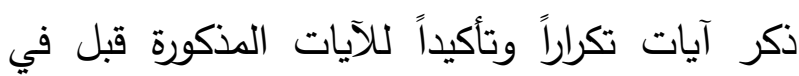
قوله: " إنّ في السماوات والأرض لآيات"ه (־). وكلام المبرد غير مقبول منه في توجيهه للآية؛

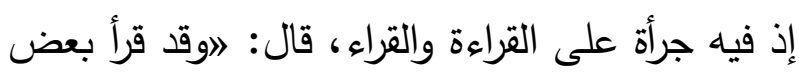
القراء ـ وليس بجائز عندنا ـ "واختلاف الليل والنهار

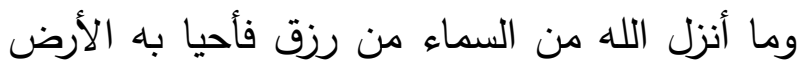
بعد موتها وتصريف الرياح آيات" فجعل "آيات" في موضع نصب وخفضها لتاء الجمع فحملها على "إنّ" ائ" وعطفها بالواو وعطف اختلافاً على "في" ولا أرى ذا

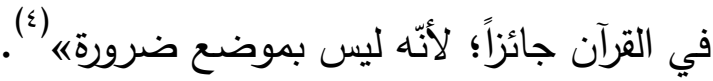
وأشار الصيمري إلى أنّ سبب رد المبرد للقراءة،

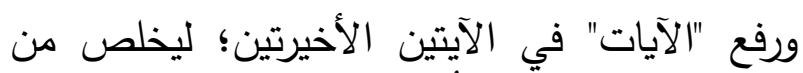

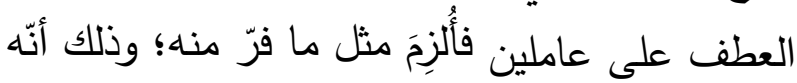


القول بالجواز مطلقاً، والقول بالهنع مطلقاً، والتتصيل بين أن يكون أحد العاملين جارًا فيجوز، أو ليس بليس

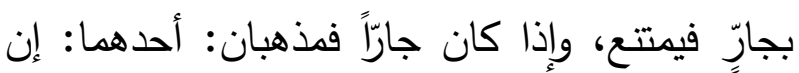

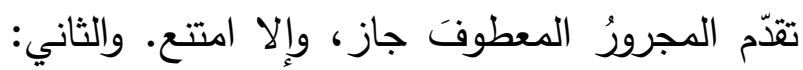
إن تقدّم المجرورُ في الدتعاطفين جاز وإلا فلاهي (०). والرأي الراجح في نظري جواز العطف على العيلى معمولي عاملين؛ لكثرة الثَّواهد الدالة على ذلكى الكلى وبالله التوفيق.

\section{$\%$}

المبحث السادس: تقديم الحال على العامل

فيها إذا كان ظرفاً.

قال الباقولي: 》إذا كان العامل متصرفاً جاز

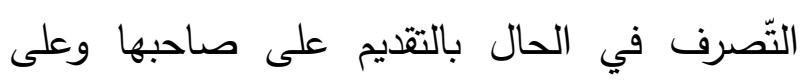
عاملها ؛ لا خلاف في ذلك، فأمّا إذا لم يكن العامل متصرفاً فإنّنه لا يجوز تقديم الحال على العائ العامل فيها،

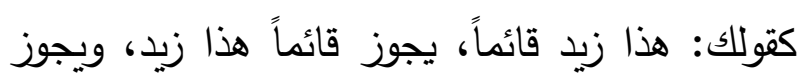

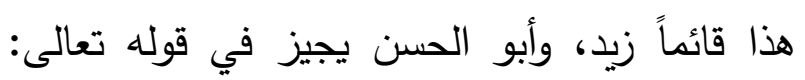

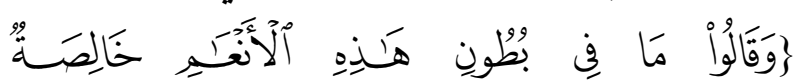

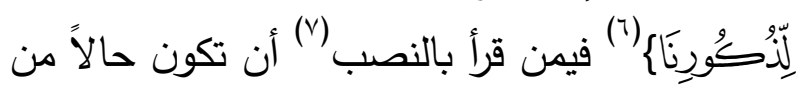
الضمير في الظرف، وهو قوله: " لذكورنا" على بلى تقدير: ما في بطون هذه الأنعام ثابتة هي لذكورنا لـانيا

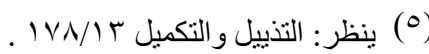

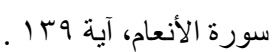

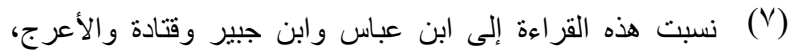

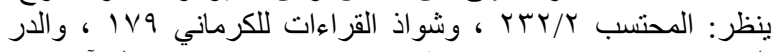

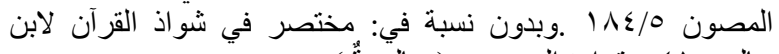

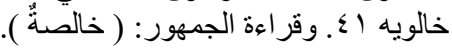

ثم ختم الباقولي كلامه بقوله: اوفي المسألة طول، وفيما ذكرت لك كفاية " ') القول الترّابع: فصّل قومٌ بين أن يتقدّم المجرور في المتعاطفين معاً، فيجوز، نحو: إنّ في الدار زيداً

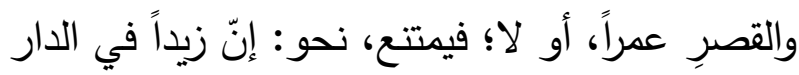

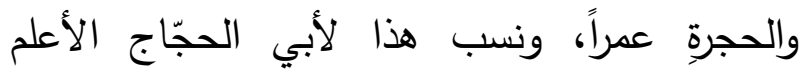

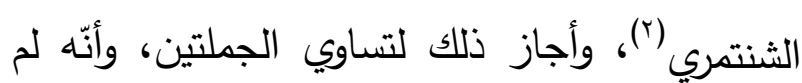

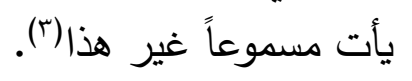

القول الخامس: أنّ العطف على عاملين إنّما

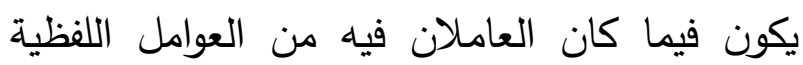

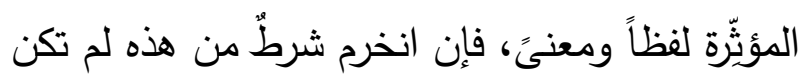

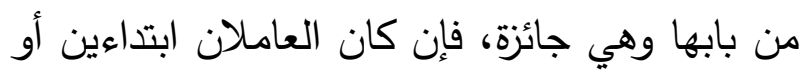

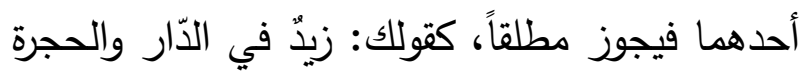

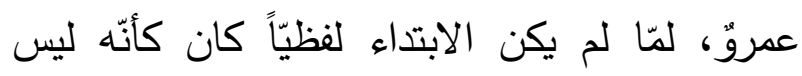
موجوداً، فكانت الواو نائبةً عن عاملٍ واحدٍ. وكذلك إذا كان العامل لفظيّاً لا معنويّاً، كالباء واء الداخلة في خبر "ليس" و "ما" و "من" في النفي، مثالٌ "من" في النفي ما شربَ من عسلٍ زيدّ و لا لبنٍ

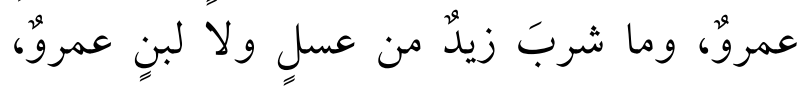

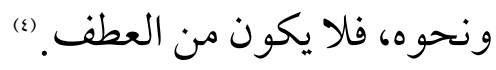
وقد لخّص أبو حيّان الأقوال في المسألة وتفريعاتها، فقال: 》افتحصّل في هذه المسألة مذاهب:

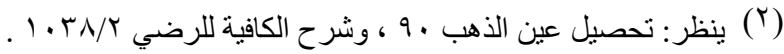

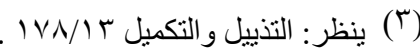

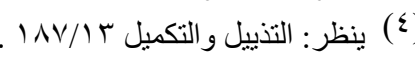


ونحن لا نجيز شيئاً من ذلك لقلة تصرف العامله

ولم يرتضها من قبل ابن السّراج، فقال: \فإن كان العامل معنى لم يجز تقديم الحال، تقول: زيد

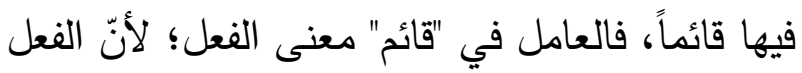

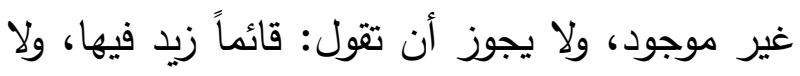

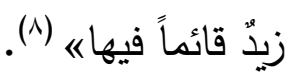

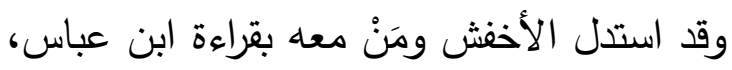
وقتادة، والأعرج: بنصب (خالصةً) من الآية السّابقة.

وقد وجّه ابن جني هذه القراءة على وجهين(9):

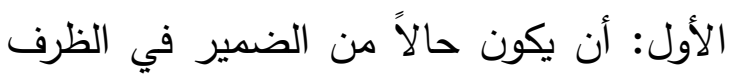
الجاري صلة على "ما"، كقولنا: الذي في الدار قائماً

وهذا التوجيه هو رأي البصريين، فتكون

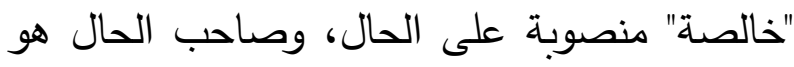

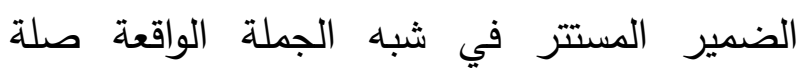
للموصول "في بطون الأنعام" والعامل في الحال معنى الفعل الموجود في الجار والمجرور، وتكون الحال غير متقدمة على عاملها ('). الثاني: أن يكون حالاً من "ما" على مذهب عالمالي أبي الحسن في إجازته تقديم الحال على العامل فيها إذا لـا

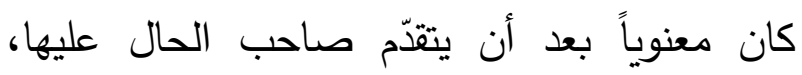

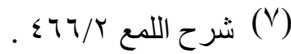

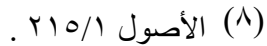

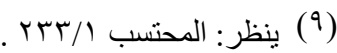

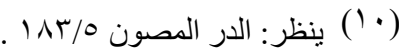

خالصة، فالعامل في الحال هو الظرف عنده، وأجاز تقديم الحال عليه، فيجيز زيد قائماً في الدّار، ويجيز مررت جالساً بزيد في تقدير مررت بزيد جالساً،

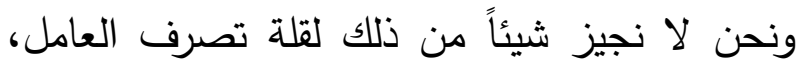

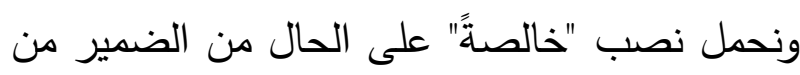

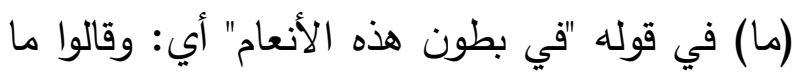

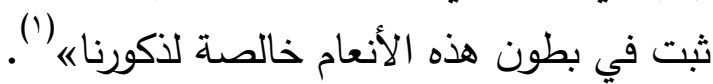

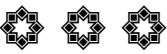

إذا كان عامل الحال ظرفاً أو مجروراً، ففي جواز تقديم الحال عليه ثلاثة أقوال:

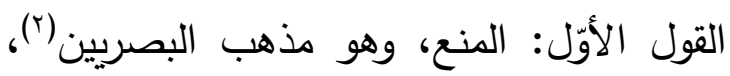

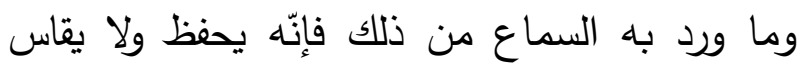
عليه عندهم. وإلى هذا ذهب الباقولي (َ).

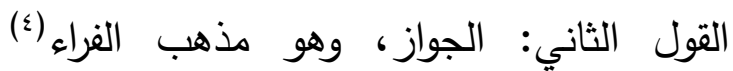
والأخفش (0)، وصححه ابن مالك (4). ولم يرتض الباقولي هذا الرأي وتعقّب الأخفش بقوله: 》افالعامل في الحال هو الظرف عنده، وأجاز تقديم الحال عليه، فيجيز زيد قائماً في الدّار، ويجيز

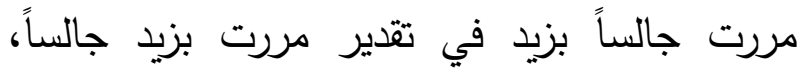

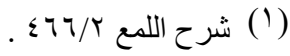

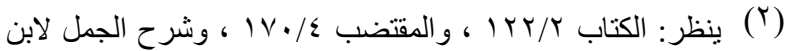

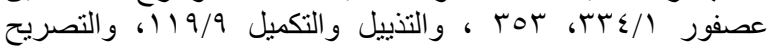

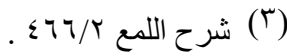

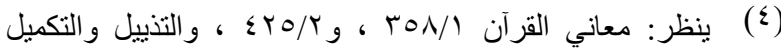

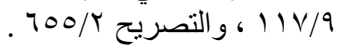

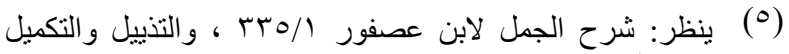

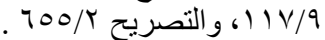

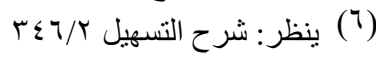


للجارّ والمجرور قبلها على أنها حال من الضمير

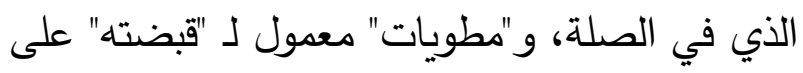

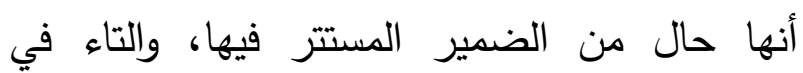
"خالصة" للتأنيث باعتبار ما وقعت عليه "ما" من من لهن

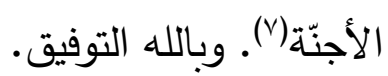

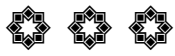

\section{المبحث السّابع: العامل في الصّفة.}

قال الباقولي: اراختلفوا في العامل في الصّفة،

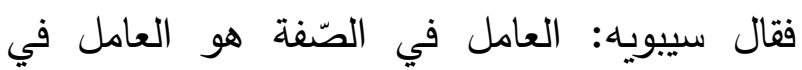

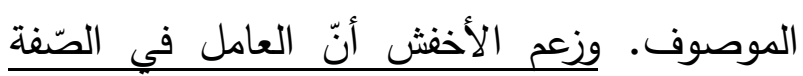
كونه تابعاً للموصوف"

\section{雾}

اختلف النّحاة في العامل في الصّفة على قولين: الأوّل: يرى سيبويه أنّ العامل في الصّفة هو في الفي العامل في الموصوف؛ إذ كانا كالاسم الواحد، قال:

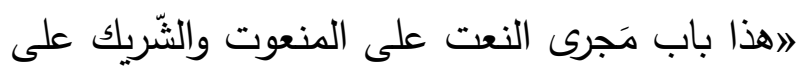
الثّريك والبدل على المبدل منه وما أشبه ذلك. فأسمّا النعت الذي جرى على المنعوت فقولك: مررثُ برجلٍ

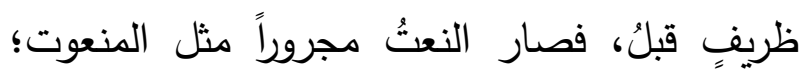
لأنّهما كالاسم الواحد) (9). وهذا الرأي متفق عليه عند جمهور النّحاة(·)

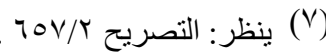

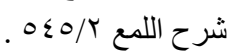

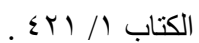

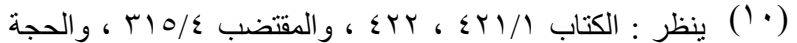

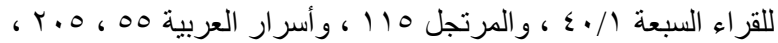

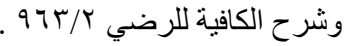

كقولنا: زيد قائماً في الدّار • وصاحب الحال وعاملها في الجار والمجرور المتأخر عنها "لذكورنا"( (1).

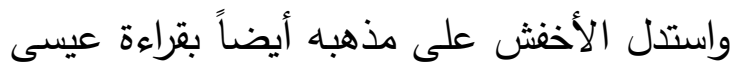

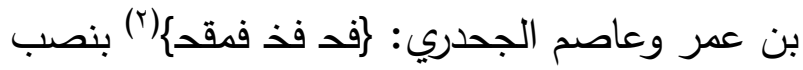

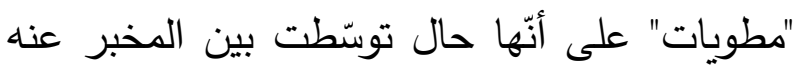

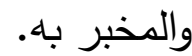

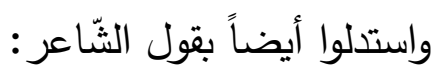
رَهْطُ ابنُ كُوزٍ مُحْقِبِي أَدْراعِهِ

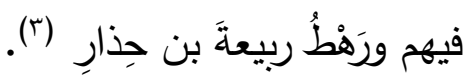
ف "محقبي أدراعهم" العامل فيه ما في قوله "فيهم" بنه من معنى الفعل، وقد تقدّم عليه(؛) وهذه الشواهد كلها تدل على جواز تقديم الحال على عاملها الظرف والجار والمجرور •

ويرى الزمخشري أنّ "خالصةًة" مصدر مؤكّد، ولا

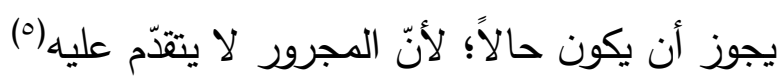
القول الثالث: الجواز إذا كانت الحال فيه من مضمر، نحو: أنت قائماً في الدار ، والمنع إن كانت إنت من ظاهر ، وهو مذهب الكوفيين(؟). والراجح قول البصريين، وهو ما قره الباقولي،

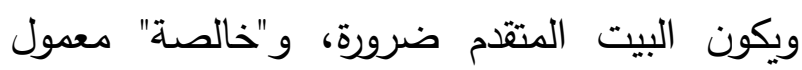


والذي يأتيني بمنزلة عبدالله، وأنت لا يجوز لك أن

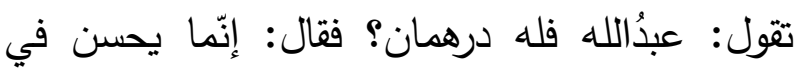
"الذي"؛ لأنّه جعل الاخِر جواباً للأوّل، وجعل الأوّل

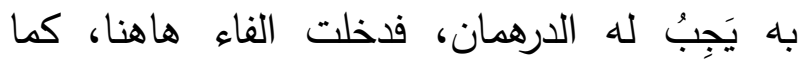
دخلت في الجزاء إذا قال: إن يأتني فله درهمان، وإن

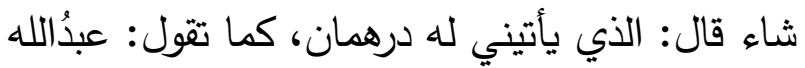
له درهمان، غير أنّه إنّما أدخل الفاء لتكون العطيّة

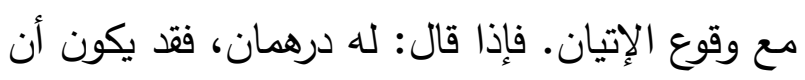
لا يوجب له ذلك الإتيان، فإذا أدخل الفاء فإنما يجعل الإتيان سبب ذلك، فهذا جزاء وإن لم يجزم؛ لإنه

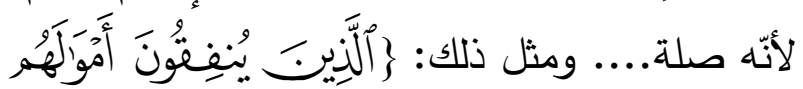

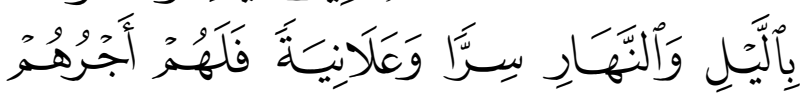

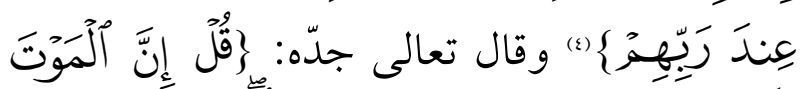

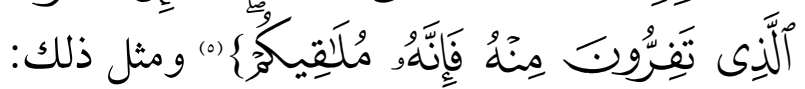

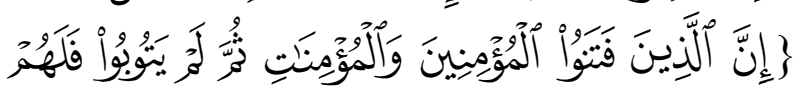

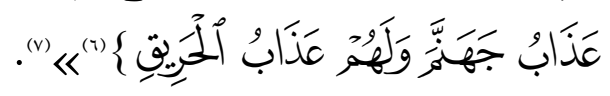

الثاني: يرى الأخفش أنّ العامل في الصّيّة

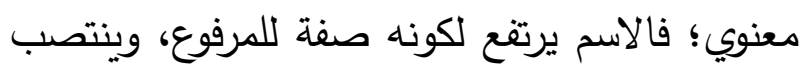
لكونه صفة للمنصوب، وينجر لكونه صفة للمجرور . فإذا قال: مررت برجل ضارب، فالجار لضارب كونه

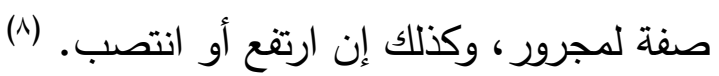

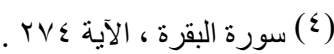

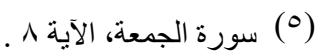

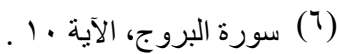

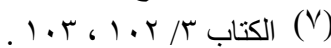

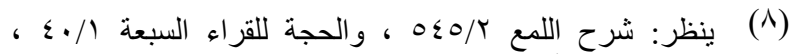

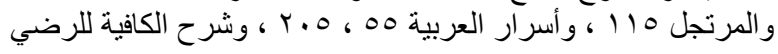

فإذا قال: جاءني زيد الظريفُ، كان العامل فيه "جاءني" وإذا قال: رأيت زيداً الظريف، كاند أندان العامل

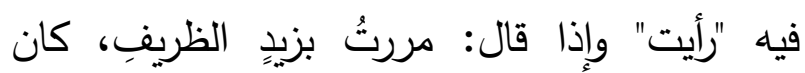

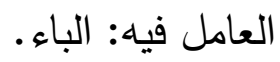

واحتج سييويه على أنّ الصّفة مع الموصوف لبه

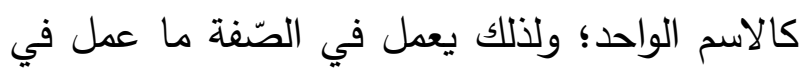

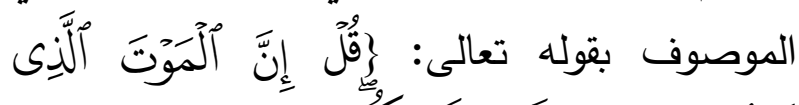

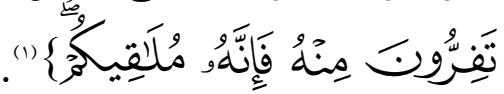
قال الباقولي: الاويحتجّ بالآية؛ لأنّ الفاء دخلت

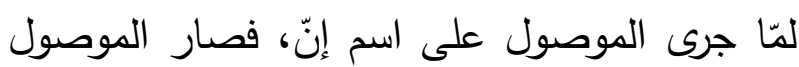

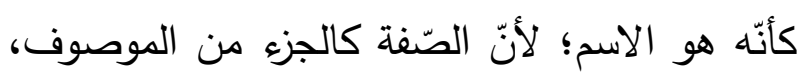

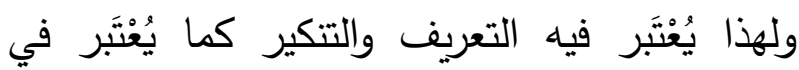

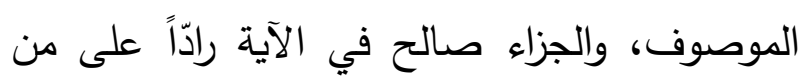
اعتقد أنّ فراره من الموت ينجيه فقال: إنّه لاق وإن إن التهاء فررتم، وهذا كما جاء: وَمَنْ هَابَ أَسْبابَ المنيَّة يَلْقَها

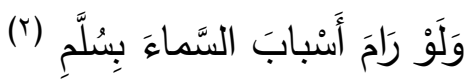
فالفاء هو على جهة الثّرط والجزاء، وليس لك لك

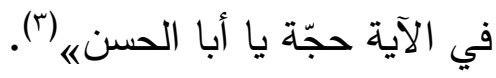
وأثار سيبويه لهذه القضية في كتابه وذكر هذا باديا الثاهد القرآني، جاء في الكتاب: الوسألته عن قوله:

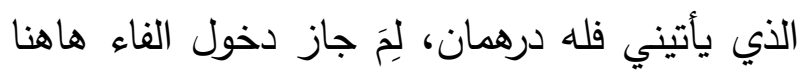

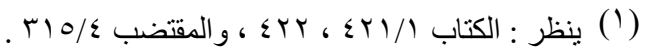

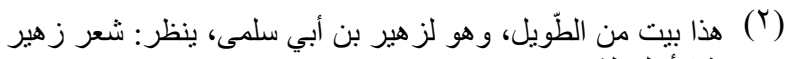

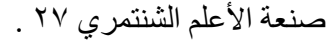

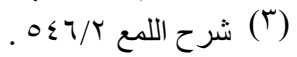


الموت صار كالجزء منه، وصار كأنّه اسم إنّ المان

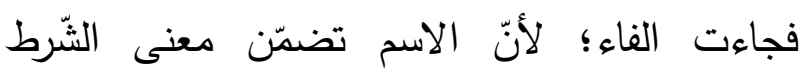

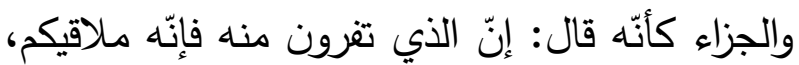

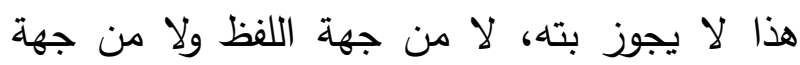

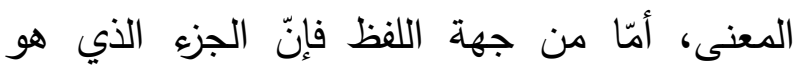

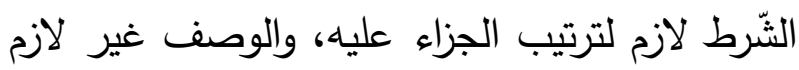

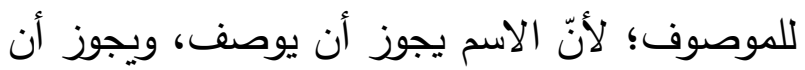
لا يوصف، فإذا لم يلزم الوصف الاسم لم يلزم إدخال الفاء في خبر الاسم؛ لأنّ وصفه بما يوجب إدخال الفاء غير لازم بخلاف الثُّرط. وأمّا من جهة المعنى فإنّ ما كان شرطاً يجوز أن يكون ويجوز أن لا يكون، والموت لاق فرّوا أو لم

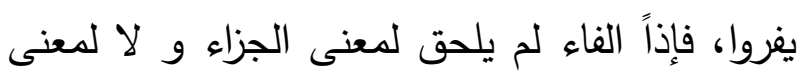

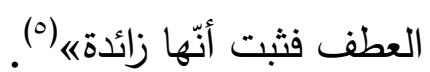
وقد عرض المفسرون للفاء في هذه الآية وأنها محتملة لوجهين: أحدهما: أنّها داخلة لِما تضمنه الاسم من معنى الثرط، وحكم الموصوف بالموصول حكم الموصول في ذلك.

وثانيهما: أنها مزيدة محضة لان لل للتمين

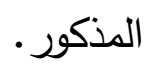

وأفسد القائلون بهذا الوجه القول الأول بأمرين:

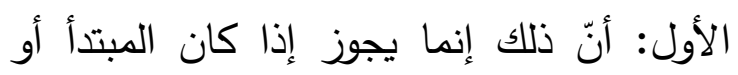

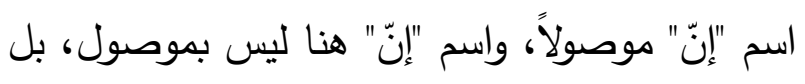

وجاء في معاني القرآن عند الأخفش: (اؤمّا

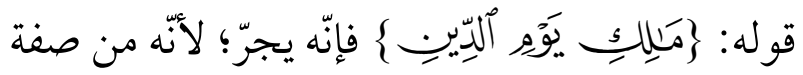

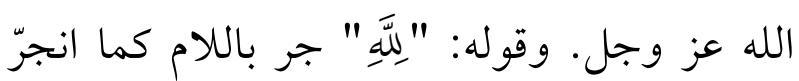

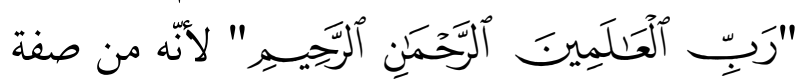

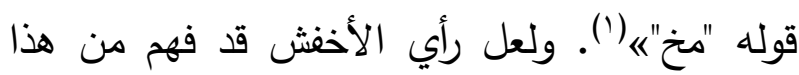

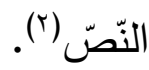
والباقولي ذكر رأي الأخف، وساق الحجج التي احتج بها؛ وهي: ا. أنّ التبعية هي العاملة، وإن كانت معنوية؛

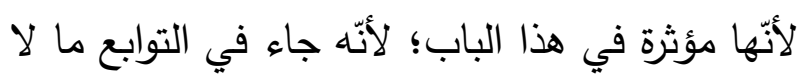

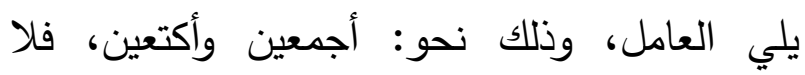
يجوز: جاءني أجمعون، فتوليه العامل، فعلم أنّ أن إعرابه إنّما هو لكونه تبعاء(").

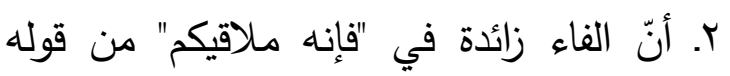

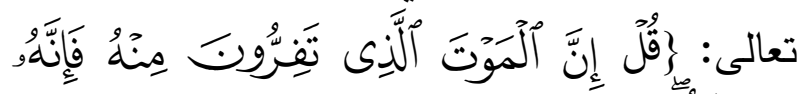

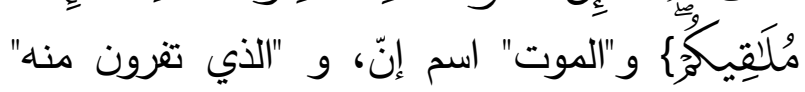

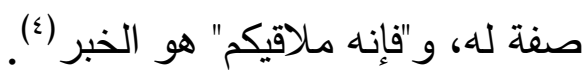
وفصّل الباقولي في بيان زيادة الفاء في الآية من جهتين؛ لفظية ومعنوية؛ قال: اولا أجعل الفاء

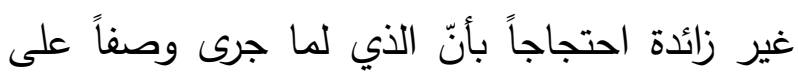


أيضاً (๕)، وذهب إليه أبو عثمان المازني فيما حكاه عنه أبو يعلى (0) وأشار إلى هذا اليه الرأي كثير من المازي العلماء (7)

وعرض أبو علي الفارسي لرأي الأخفش هذا وما

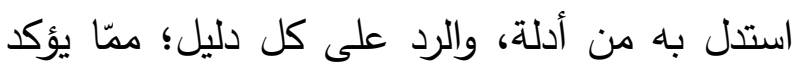

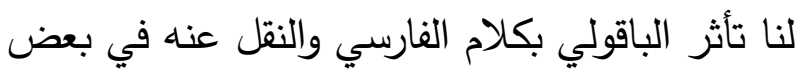
المواضع بدون تصريح، وأضاف الفارسي دليلاً ثالثاً

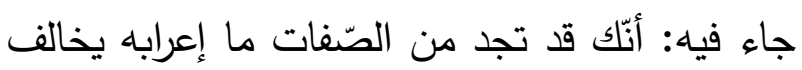

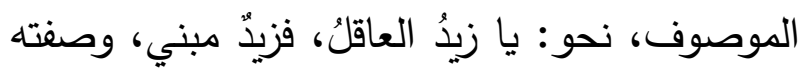

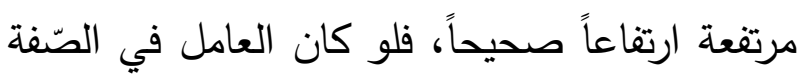
العامل في الموصوف لم تختلف حركتاهما، فكانت إحداهما إعراباً، والأخرى بناءً، وكان مجيء هذا لهاء في

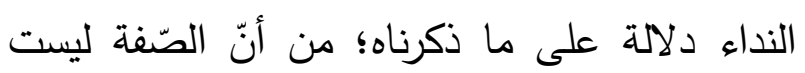

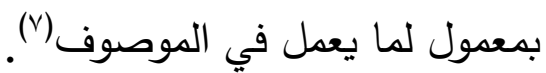
والحقّ أنّ جعل العامل معنوياً كما ذهب إليه الأخفش هو خلاف الظّاهر؛ إذ العامل المعنوي في كلام العرب بالنسبة إلى العامل اللفظي كالثّاذ

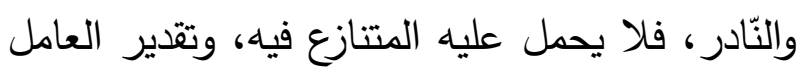
خلاف الأصل أيضاً، فلا يصار إلى الأمر الخفي إذا أمكن العمل بالظاهر الجلي(^).

(ع) ينظر: معاني القرآن للفراء 100/r)، 107 ـ وينظر : البحر المحيط . $\mid V T / 1$.

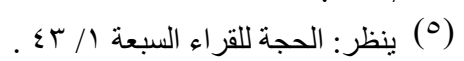

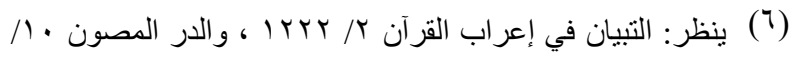
o r p

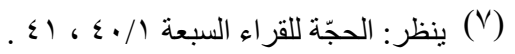

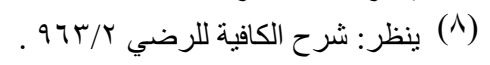

موصوفت بالموصول. الثاني: أنّ الفرار من الموت لا يُنْجي منه، فلم يُشْبَه الثرط الذي هو من شأنه الاحتمال.

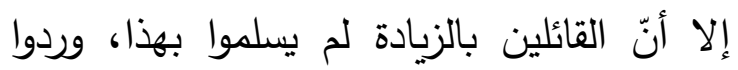

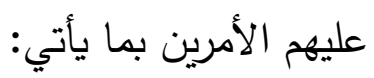
الأمر الأول: أنّ الموصوف مع صفته كالثيء الواحد، ولأنّ "الذي" لا يكون إلا صفة، فإذا لم يُذكر الموصوف دخلت الفاء، والموصوف مرادٌ، فكذلك إذا لإداد

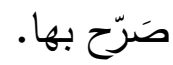
الأمر الثاني: أنّ خلقاً كثيراً يظنون أنّ الفرار من أسباب الموت يُنجيّهم إلى وقت آخر (1). ولم يرتض الباقولي كلام الأخفش وردّ هذه إنه الحجج؛ إذ نصّ في رده على النقطة الأولى بقوله:

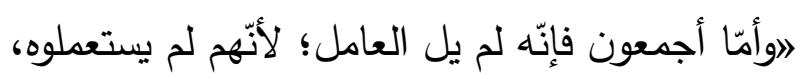

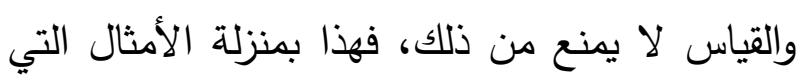
تحكى ولا تغيّر من جهة السّماعه(؟). وفي حديثه عن رأي سيبويه وتوجيهـ للآية

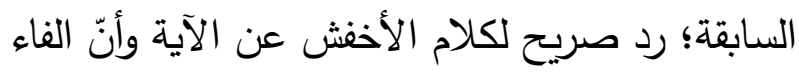

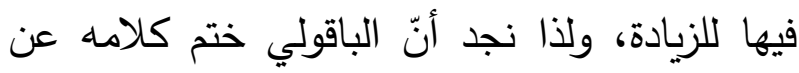
ذلك بقوله: اوليس لك في الآية حجّة يا أبا لباديا

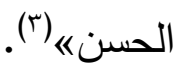
ومجيء الفاء للزيادة في الآية هو رأي الفراء

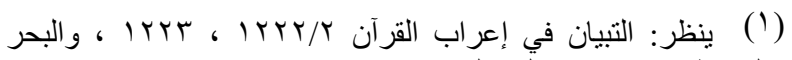

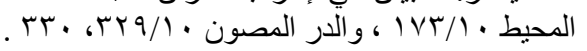

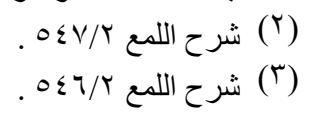




\section{صلة لأي" \\ 雷}

لا يجيز سيبويه في "الرجل" من "يا أيها الرجل" لهاه

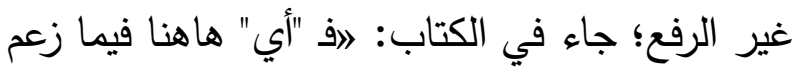
الخليل رحمه الله كقولك: يا هذا، والرجل وصفت له له اله

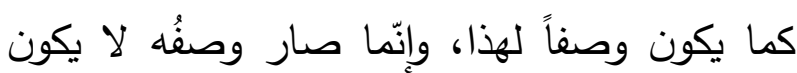

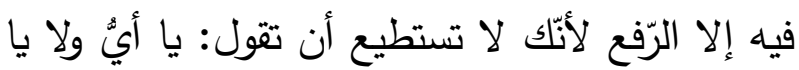

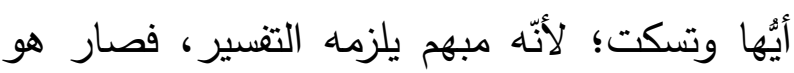

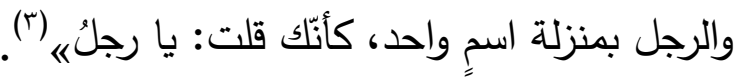
ووقفت على نصوص أخرى لسيبويه عن هذا لـا الأسلوب "يا أيها الرجل" قال في موضع: الهوصن أهّا الألف والهاء اللتان لَحِتا أيّّ توكيداً، فكأنّاك كرّرت "يا" مرتين إذا قلت: يا أيّها، وصار الاسم بينهما كما لوان

صار هو بين ها وذا، إذا قلت: ها هو ذاهاء (๕). وعلّق أبو علي الفارسي على هذا الكلام شارحاً

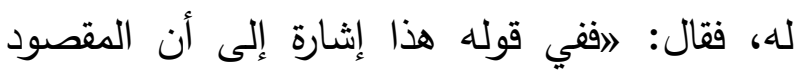

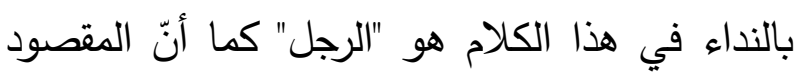
بالإشارة في قولهم: "ها هو ذا" الاسم المبهم دون المضمر، والمضمر قد اعترض بين حرف الإشارة

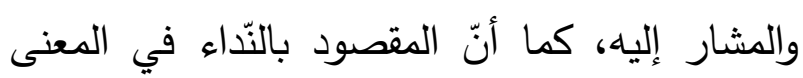
من قولهم: يا أيها الرجل هو "الرجل" وإن كان النداء أن النهاء

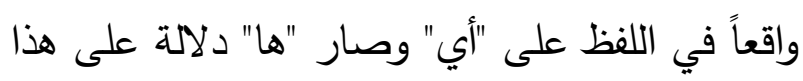
المعنى، وعلى أنّ المنادى الأول لا يجوز الاقتصار لهار دلها

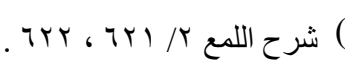

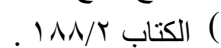

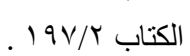

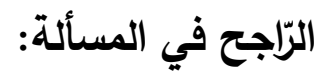

مذهب سييويه هو الراجح في المسألة، وهو

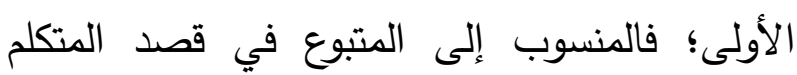
منسوبٌ إليه مع تابعه؛ فإنّ المجيء في جاءني زيدٌ الظريف ليس في قصده منسوباً إلى زيد مطلقاً، بل

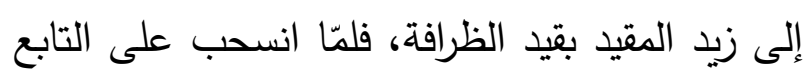
حكم العامل المنسوب معنى، حتى صلى صار التابع والمتبوع معاً كمفردٍ منسوب إليه، وكأنّ الثاني هو هوني

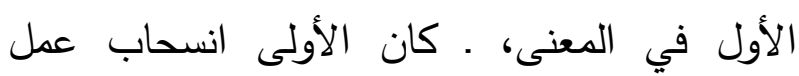

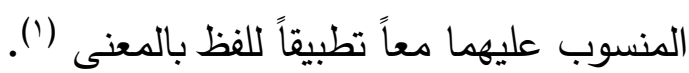

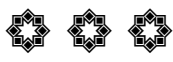

المبحث الثّامن: "أي" بين الصّفة والموصول. قال الباقولي: اواعلم أنّ كل اسم فيه الألف واللام لا يدخل عليه حرف النداء؛ لأنّ حرف النداء للتعريف والإشارة، والألف واللام للتعريف أيضاً فلا يجتمعان، فإذا أرادوا ذلك جاءوا بأي وجُعل الاسم الذي فيه الألف واللام وصفاً لأي، كقولك: يا أيها إدائ

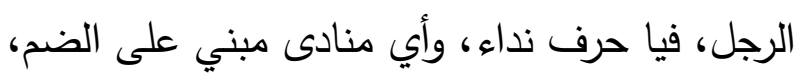

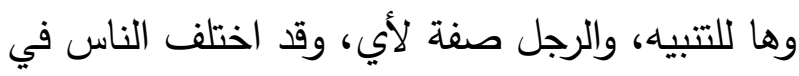
هذه اللفظة من أوجه: الأول: أنّ مذهب سيبويه أنّ " وضّا

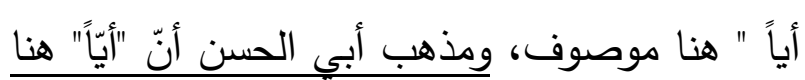

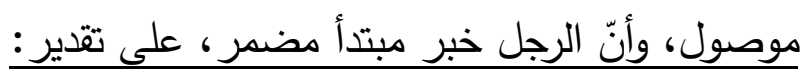
يا أيها هو الرجل، والجملة صلة لأي، وهذا خطأ؛ لأبك لأنّ هذا المضمر قط لم يظهر ها هنا فكيف يكون

$$
\text { (1) ينظر : شرح الكافية للرضي ك/rا 9 . . }
$$


قال الرضي: اويصحّ تقوية مذهبه بكثرة وقوع "أي" موصولةً في غير هذا الموضح، وندور كونها

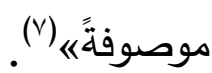

ولم يرتض الباقولي رأي الأخفش وخطأه بقوله: اوهذا خطأ؛ لأنّ هذا المضمر قط لم يظهر ها هنا

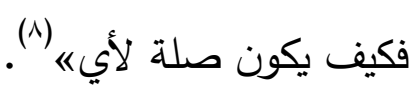
ولم يرتض كثير من العلماء هذا الرأي من الأخفش، وكثرت الردود عليه، وبيانها فيما يأتي: ا. لا يجوز أن تكون "أي" في النّداء موصولة؛ لألياء إذ لا يوجد في جميع هذه الأسماء الموصولة شيئاً

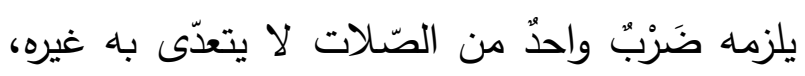

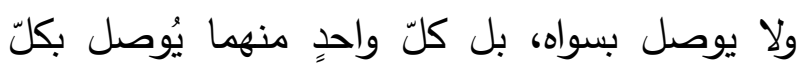

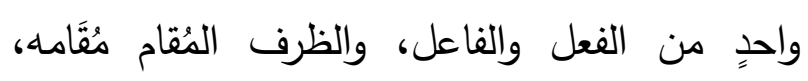
والمبتدأ والخبر ، والثّرط والجزاء، فلو كانت "أي" في ولفي

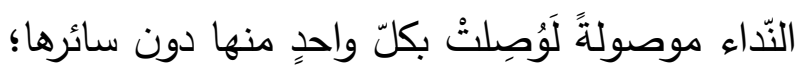

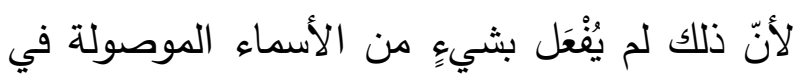

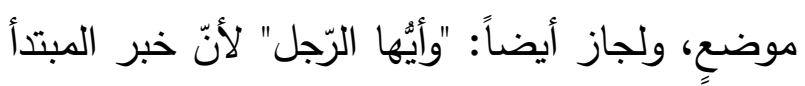

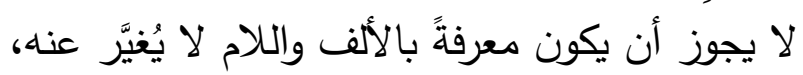

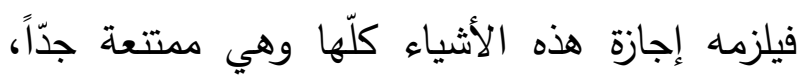
وفي امتتاعه وامتتاع العرب وجميع النحويين من إناء إجازة ذلك ما يدلّ على فساد هذا القول وانكساره، فإذا فسد ذلك فسد كلّ قياسٍ عليه، وثبت أنّها موصوفةٌٌ ليست موصولةًَ).

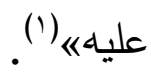

وقال سيبويه في موضع آخر: اولا يكون هذا

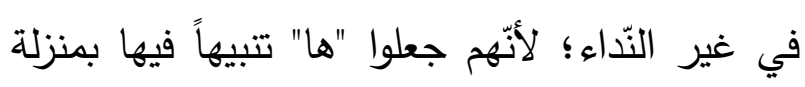

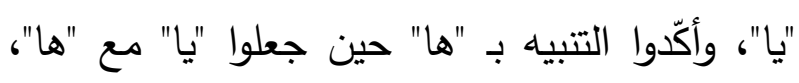
فمن ثََّّ لم يجز لهم أن يسكتوا على أيّ، ولزمهـ التفسير «( آن.

وعلّق الفارسي على هذا الكلام قائلاً: "ايقول: لمَّا كان "ها" بمنزلة "يا" وكنت إذا كرّرت "يا" لم يجز لفز

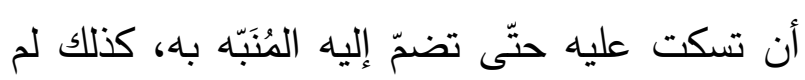
يجز أن تسكت على "ها" ولا تذكر قولك: الرجل إذ إذ إله

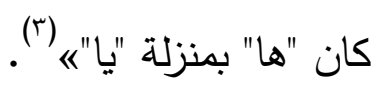

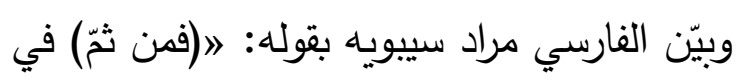

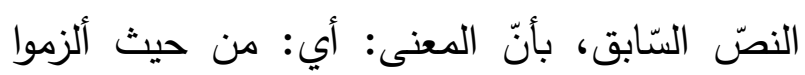

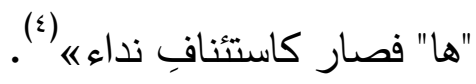

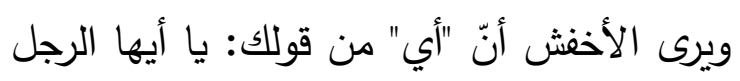

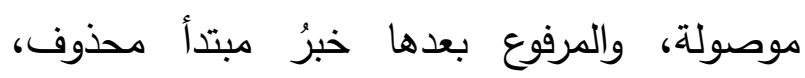
والجملة صلة أيّّ(0)، وإنّما وجب حذف هذأف هذا المبتدأ لمناسبة التخفيف للمنادى، ولا سيّما إذا زِيدَ عليه كلمتان، أعني: أيّهاب(").

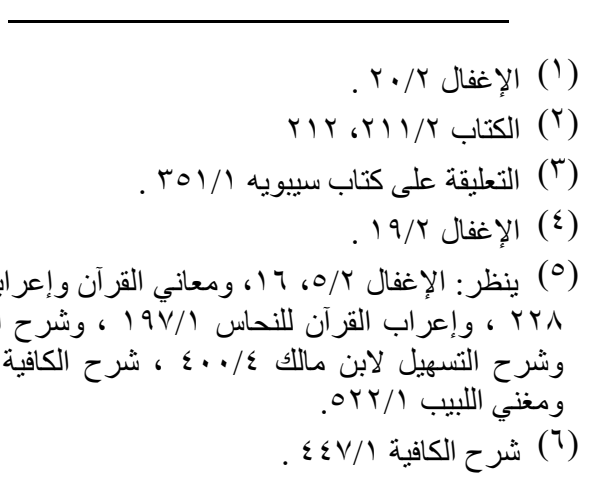


على ما ذهب إليه. وما ذهب إليه أولى؛ لأنّها لا تكون اسماً في غير الاستفهام والمجازاة والوصف به بهاه إلا بصلة 《) (0) ○. أنّ "أي" لو كانت موصولة لجاز ظهور المبتدأ، ولكان أولى من حذفه؛ لأنّ كمال الصّلة

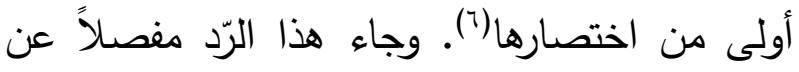

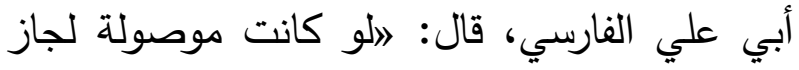
إظهار المبتدأ المحذوف من الصّلة، فكان يجوز يا يا أيّها هو الرّّل، ويا أيّها هي المرأة؛ لأنّ كل موضع

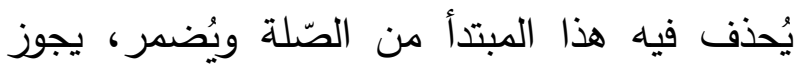
إظهاره، بل الإظهار هو الوجه، والإضمار مستقبح

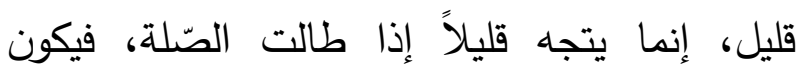
عوضاً من المحذوف، كنحو ما حكاه الخليل من قول بعضهم: ما أنا بالذي قائلٌ لك شيئًا، ولم تطل الصّلة هنا فيحسن الحذف، ولم يُحذف ذلك في موضعِ إلا بالا

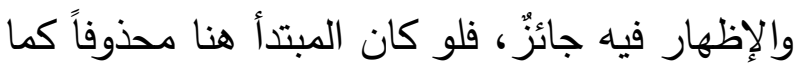

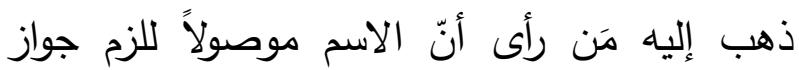
إظهاره《) (v)

ولم يُسلم أبو حيّان هذا الكلام لابن مالك، وبيّن أنّ للأخفش أن يقول: التزمَ حذف المبتدأ وإبقاء الخبر ؛ لأنّ النّداء بابُ حذفٍ وتخفيفٍ بدليل جواز الترخيم فيه، ولا يجوز في غيره إلا ضرورةً، وصار

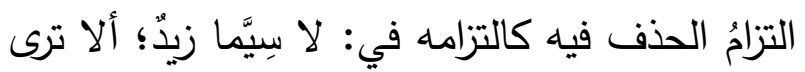

r. لو كانت "أي" موصولة لجاز حذف "ها" من الكلام، ولم يلزم إثباتها؛ لأنّ حرف التتبيه كذلك إذا هان

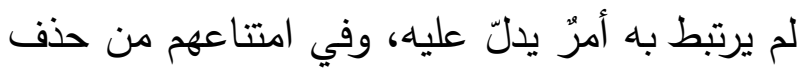
"ها" في هذا الموضع وإلزامهم إيّاه، ما يدلّ على لهى

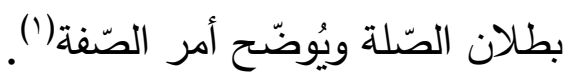
r. لو كان الرّجل في "يا أيّها الرجل" صلة غير صفة لوجب أن يكون جملة، ولم يكن اسماً مفرداً؛

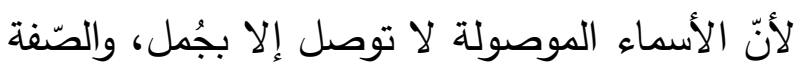
هنا تبيّن كما تبيّن الصّلة، فإن أراد هذا القائل بقوله:

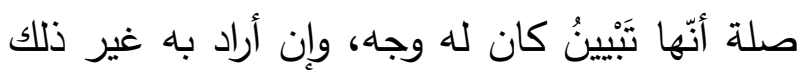

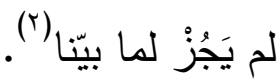
ع. أنّ "أي" لو كانت موصولة لوصلت بالظّرف

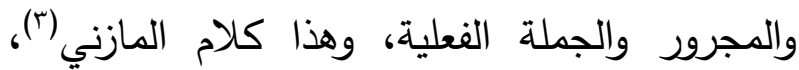
وقال به ابن مالك (q). ونقل أبو حيّان عن بعض أصحابه ردّاً على ابن

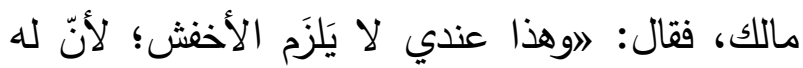

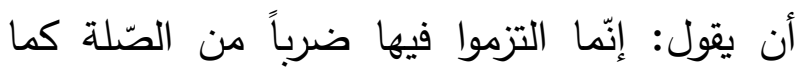

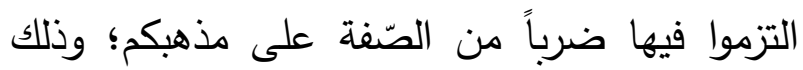

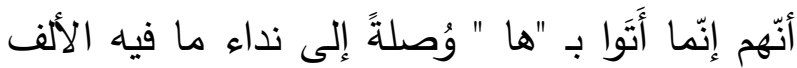

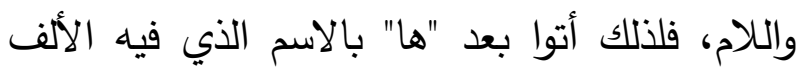
واللام، إمّا على طريق الصّفة كما ذهبتم إليه، وإمّا على جعله خبراً لمبتدأ مضمر، والجملة صلة لأيٍّ

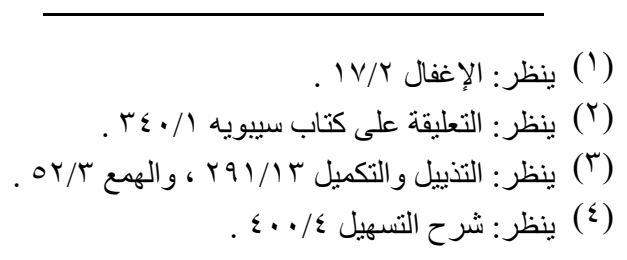


وهذا الرّد نسبه أبو حيّان إلى بعض أصحابه ولم يسمهم.

وأُجيب عليهم: بأنّ "ها" عوّضت فيها من فن فئن

المضاف المحذوف فجرت مجراه، فكأنّها مضافة(؟). ^. نقل ابن هشام ردين على الأخفش، وأجاب

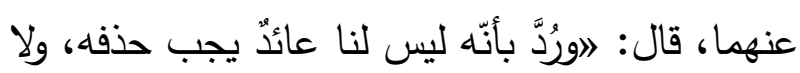
موصولّ التزم كونُ صلته جملة اسمية.

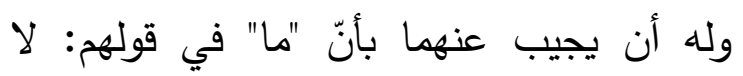

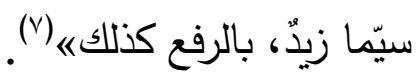

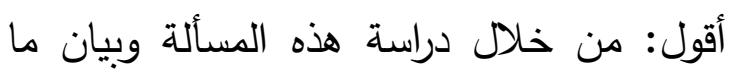
جاء فيها من آراء، نجد أن الباقولي محق في تعقبّه

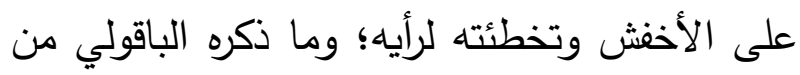
تعقّب هو أحد الردود على رأي الأخفش، وقد أوردنا

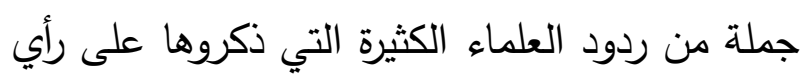
الأخفش؛ ممّا يدل على ضعف ردود العلى أيه، وأنّ الرأي الصحيح هو ما ذهب إليه سيبويه، والخليل (^). وبالله

\section{称}

المبحث التّاسع: "ما " المصدرية بين الاسميّة

والحرفية.

قال الباقولي: "اؤمّا إذا كانت "ما" حرفاً فعلى

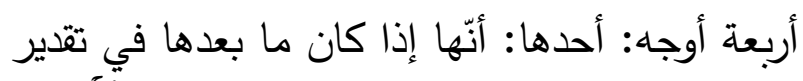

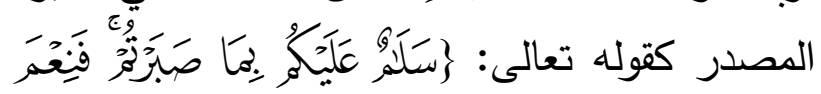

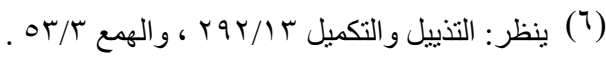

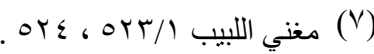

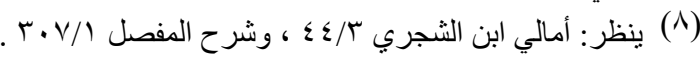

أنّ زيداً خبر مبتداً محذوفٍ، والتزمت العربُ حذفه، زداِ وذلك إذا رفعت زيداً (') ז. أنّ "أي" لو كانت موصولة لوند لونب ألا تُضمّ؛

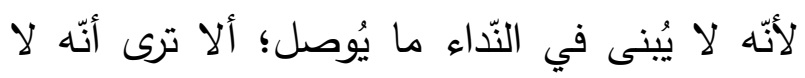

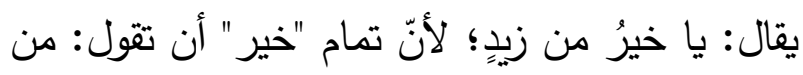

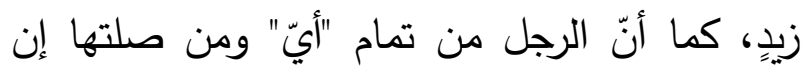

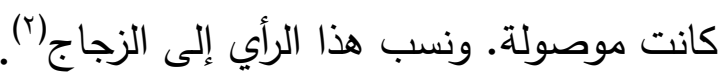
ونقل أبو حيّان عن بعض أصحابه ردّاً على هذا الكلام، قال: اوهذا إنما يلزمها إذا قدّرناها معرفةً قبل ئل

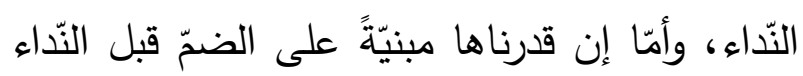
فلا يلزم ذلك فيها؛ لأنّ المبنيَّ قبل النّاء يبقى في

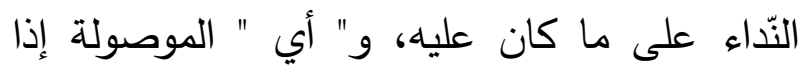

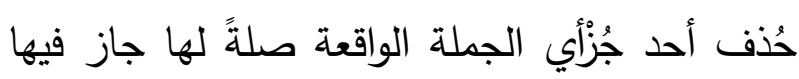
البناء والإعراب؛ فمن أعربها كان ينبغي له إذا أدخل

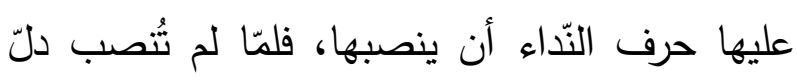
على بطلان ما ذهب إليهه" (َ). وعقّب أبو حيان بعد هذا النقل قائلاً: اوله أن

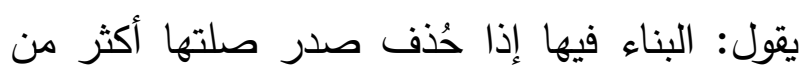
الإعراب، فالتزموا فيها في النّداء الأكثره (؛).

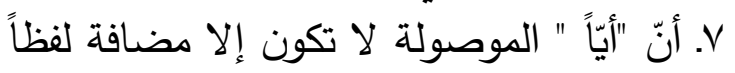

أو نية، والإضافة منتفية في هذه بوجهيها(ه).

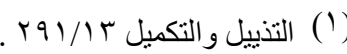

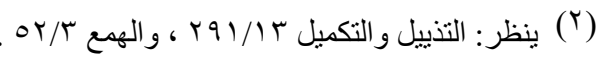

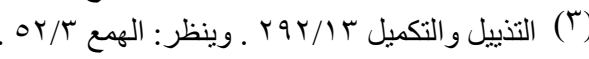

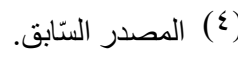

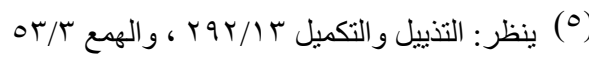


القول الثّاني: أنّها اسم، بمنزلة "الذي" إن كانت

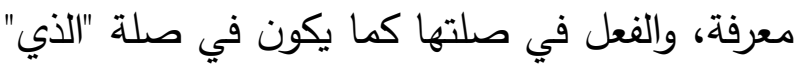

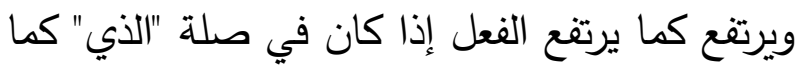
تكون نكرة في تقدير شيء، ويكون الفعل بعدها صفة

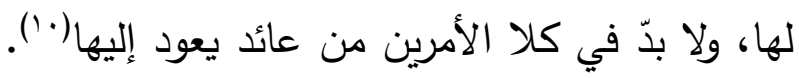

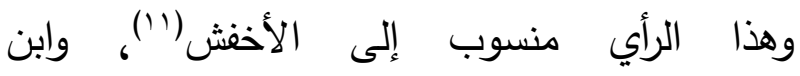

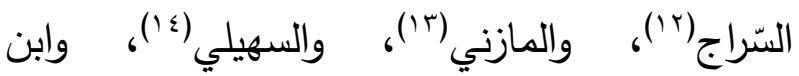
الحاجٌ(10)، ونسب أيضاً إلى بعض الكوفيين(17')

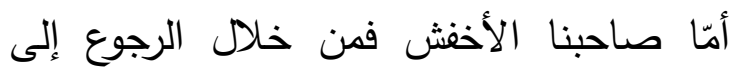
كتابه معاني القرآن نجد أنّ له قولين في المسألة:

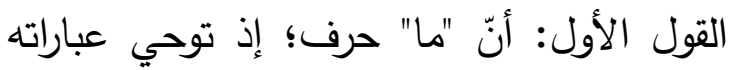

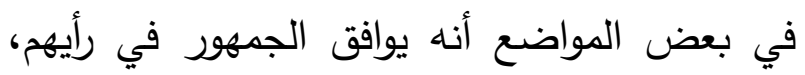
وإليك هذه النصوص:

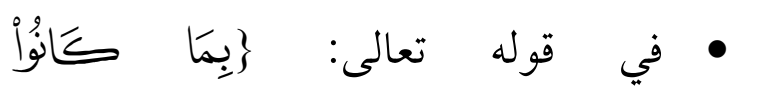

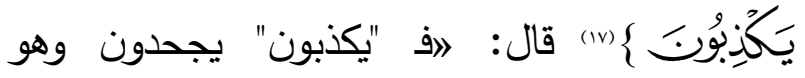

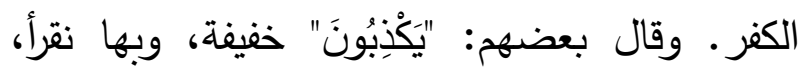

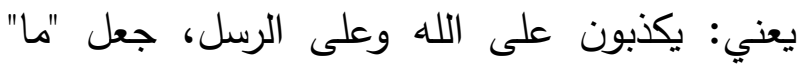
والفعل اسماً للمصدر كما جعل "أنْ" والفعل اسماً

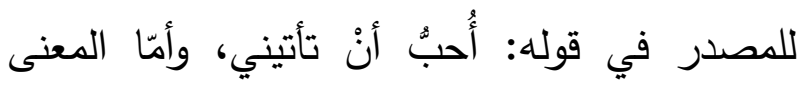

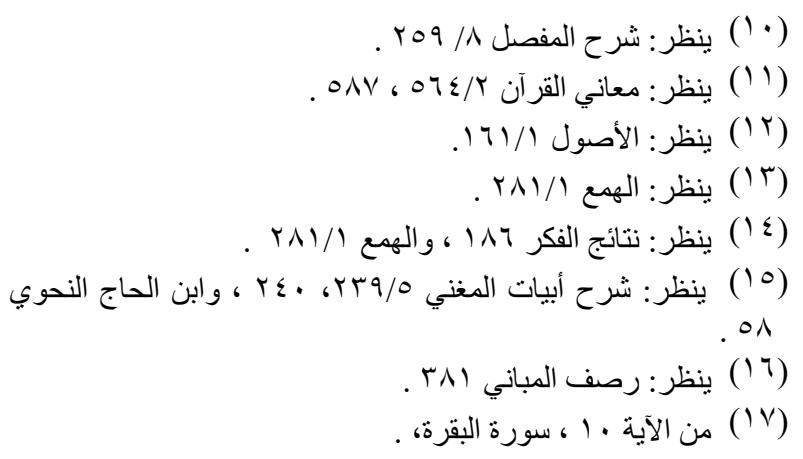

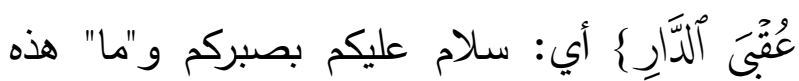

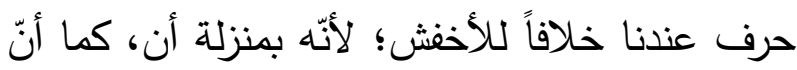

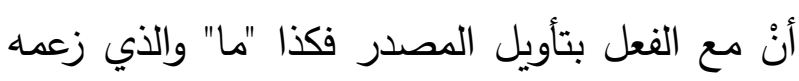
الأخفش باطل؛ لأنّّه لا يكون اسم موصول بغلير عائد يعود إليه من صلته، وليس في قوله: "صبرتم" لأند عائد يعود إلى "ما" لا ظاهراً ولا مضمراً، وأنشدوا:

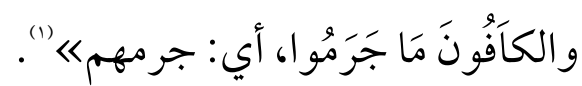

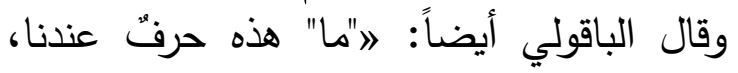
وعند الأخفش اسم" (؟).

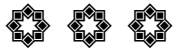

اختلف النّحاة في "ما" المصدرية أهي حرف أم

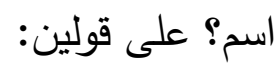

القول الأوّل: أنّها حرف؛ لأنّها بمنزلة "أن" إلا أنّها لا تعمل عملها، ولا تحتاج حينئذ إلى عائد، فإذا لها قلت: أعجبني ما قمتَ، فتقديره: قيامك، وهذا مذهب تهب

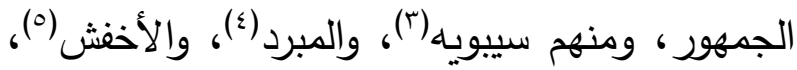

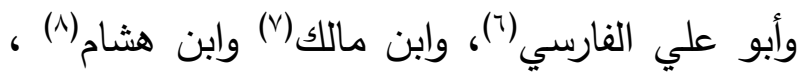
وغيرهم (9).

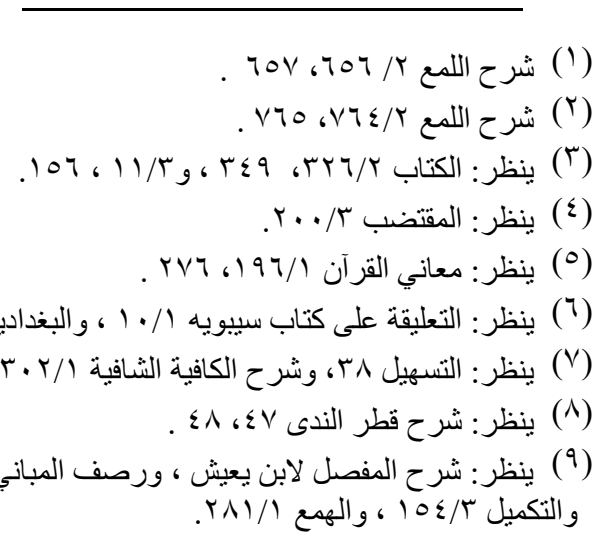


قمت؛ لأنّه لا يتعدّى، وقد خلَّط، فأجاز مثله، والقياس والصّواب قول سيبويهه| (^).

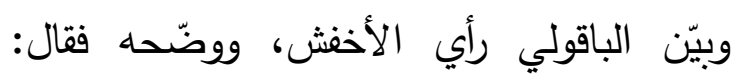
"ا"ما" هذه حرفت عندنا، وعند الأخفش اسم؛ لأنّّ

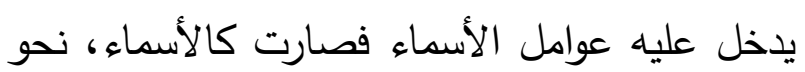

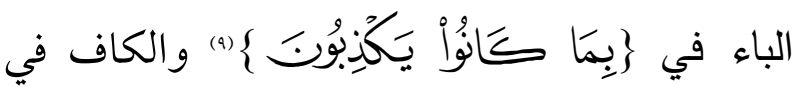

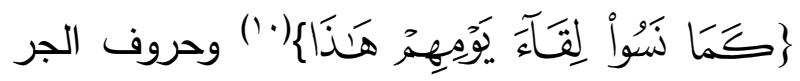

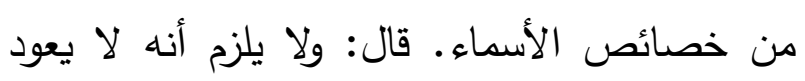

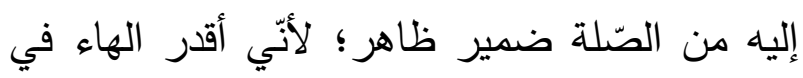

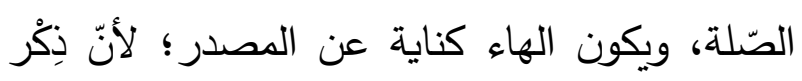

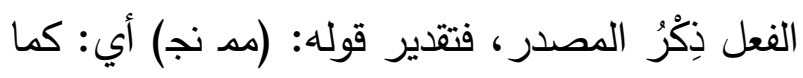

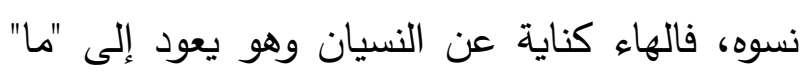

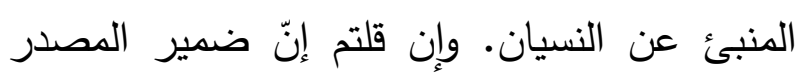
ليس كصريحه بدليل امتناع قولهم: مروري بزيد

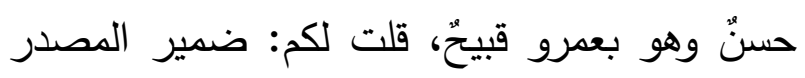
وإن خالف صريحه في هذا فلم يخالفه في تعدية الفعل إليه، ألا ترى أنّا نقول: أعجبني قيامُ قمته فئه فتُعدى قمت إلى ضمير قيام، كما تقول: قمت قياماً، وتقول: ضربته زيداً، كما تقول: ضربت ضرباً زيداً،

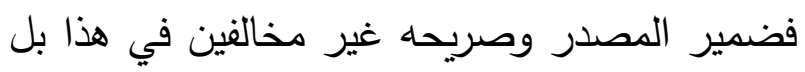
هما متفقان فلا وجه لإنكار إضمار هذه الهاء في

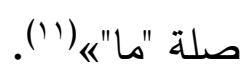

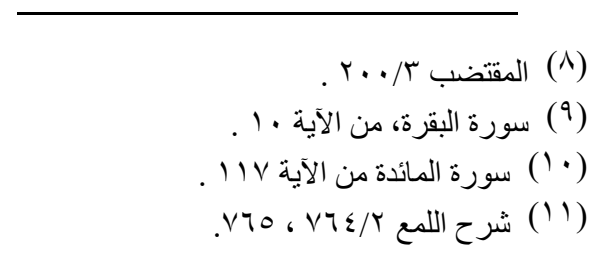

فإنما هو بكذبهم، وتكذيبهمه(')

في قوله تعالى: $\}$ نى ني\{(r) قال: "جعله

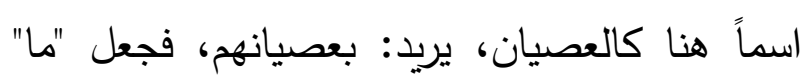
و"عصوا" اسماً) (). القول الثّاني: أنّ "ما" اسم، وقد ذكر ذلك في

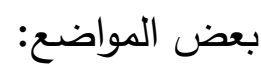

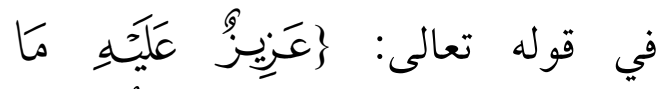

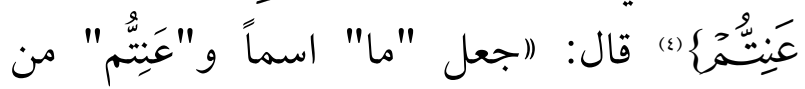
صلته 《)

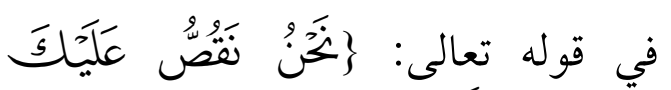

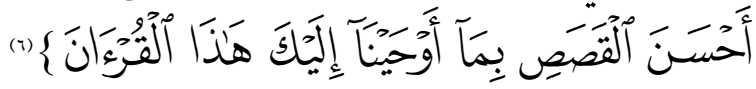

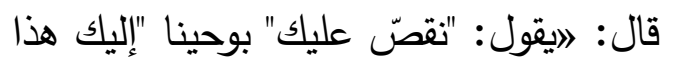

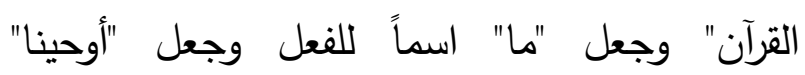
صلة والقول باسمية "ما" ونسبته إلى الأخفش نصّ عليه المبرد؛ قال: او"ما" عند سييويه إذا كانت والفعل مصدراً بمنزلة "أن". والأخفش يراها بمنزلة المالة "الذي" مصدراً كانت أو غير مصدر لـ ـ ... والأخفش

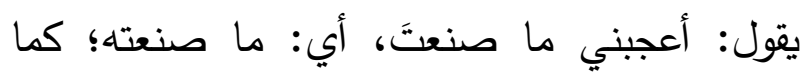
تقول: أعجني الذي صنعته، ولا يجيز : أعجبني ما مانعانها

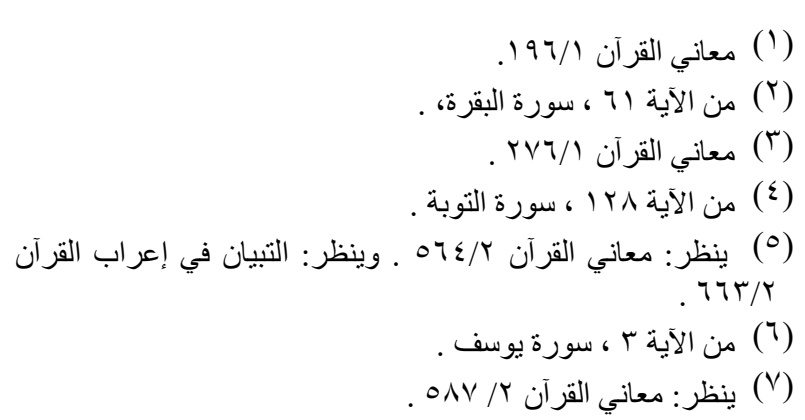


أي: يدرس الدرسَ، وأمّا إذا لم يكنْ في اللفظ

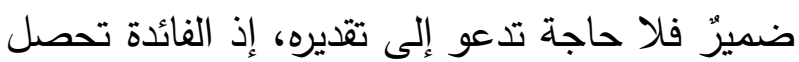

دونه، فاعلمه ${ }^{(r)}$

الأدلة التي احتجّ بها القائلون بحرفية "ما" ما

يأتي:

ا. وقوع صلتها بعدها خالية من ذِكْرِ يعودُ إليها،

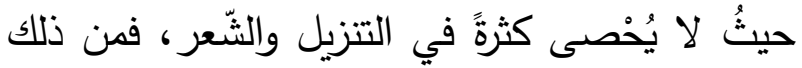

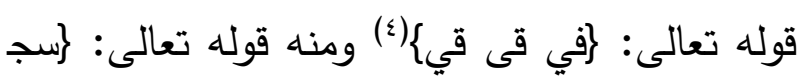

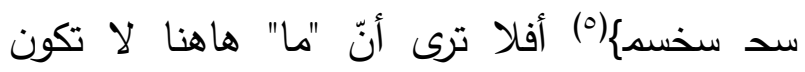

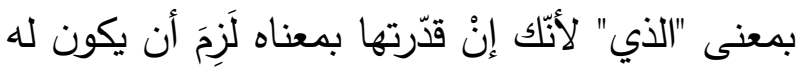

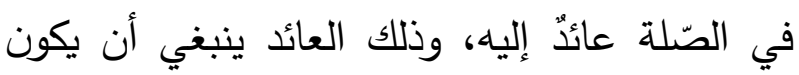

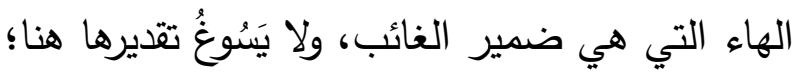

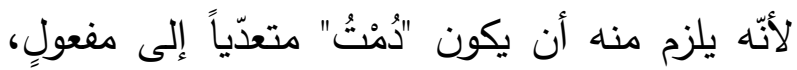

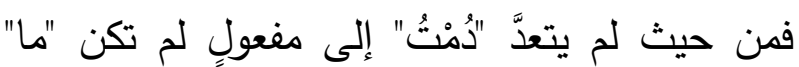
هذه اسماً (?). ومما يستدل به على ذللك أيضاً قوله تعالى:

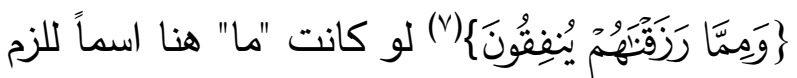

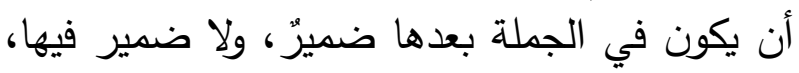

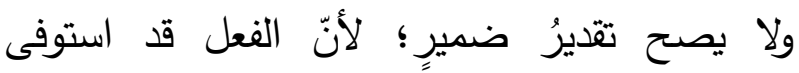
مفعوله (^). وقد وضّح ذلك أبو علي الفارسي فقال:

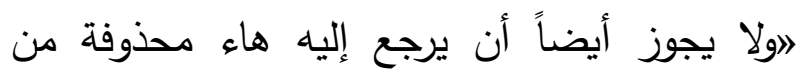

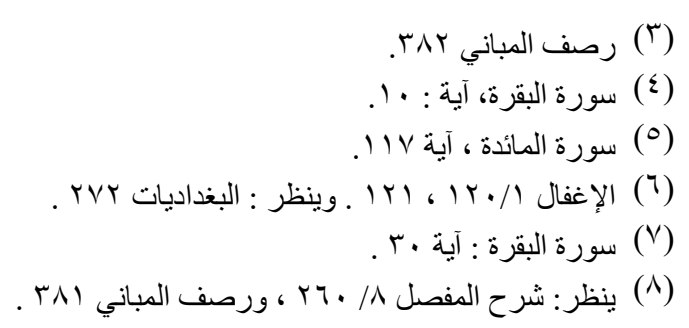

إلاّ أنّ الباقولي لم يرتض قول الأخفش وردّ عليه؛ فقال : لاونحن نقول: إنّ "ما" ها هنا حرف لرن لران

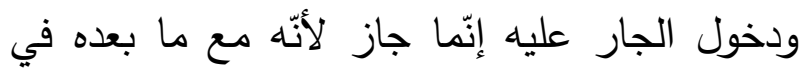

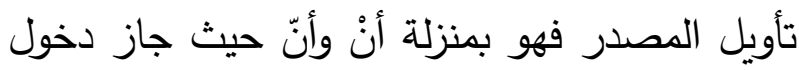
الجارّ عليه في قولك: عجبت من أنْ قمت لما كان في تأويل قيامك، فهو إذن حرف، وقد نصّ سيّل فيويه

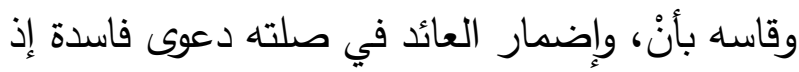
لم يظهر في موضع ولا يحتاج إلى إضماره في

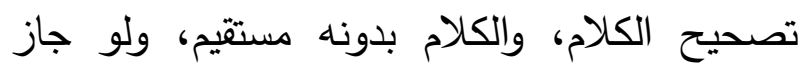
لأحد ادعاء ذلك لجاز مثله لآخر في أنْ وفي أنْ لم يُضْمر أحدٌ هاء في صلة أن دليل على مثله في "ما" (')

ووضح المالقي رأي الأخفش إلا أنه لم يرتضه فقال: "والأخفش يجعلها إذا كانت مصدرية اسماً،

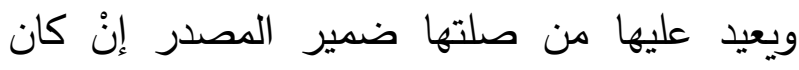
الفعل غير متعدّ، وكذلك إنْ كان الفعل متعدّياً، فإذاذا

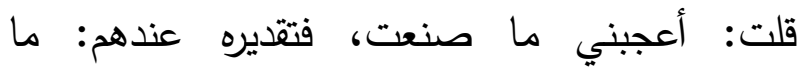
صنعته، الهاء تعود على "ما" التقدير عندهم: الصّنع الذي صنعته. وهذا تكلّف لا ضرورة تدعو إليه، وإن كان يمكن أنْ يقال به إن كان ضمير المصدر بان بارزاً

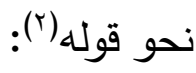

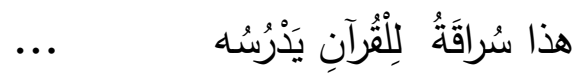

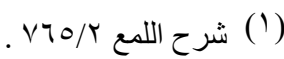

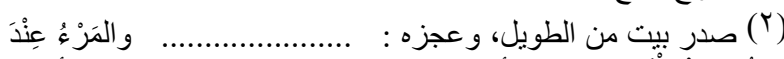

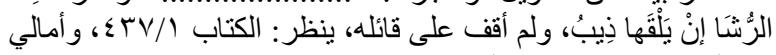

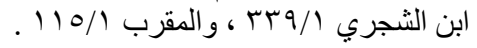


الصّلة، على أن يكون التقدير: وممّا رزقناهُموه، الإضماره(؛). r. استدلوا بقول الثاعر:

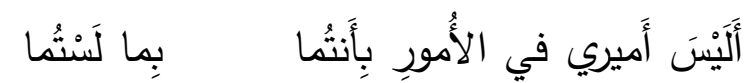

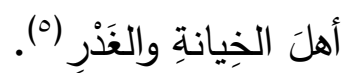

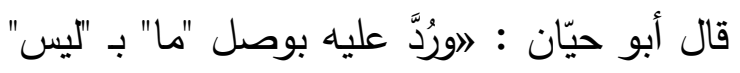

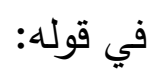

بِما لَسْتُما أهلَ الخِيانةِ

$$
\text { والغَذْرِ }
$$

ألا ترى أنّه لا يسوغ تقدير "ما" هنا بـ "الذي"

لعدم الرّابطه (־).

وقال ابن هشام: لاوبهذا البيت رُجّح القوكُ

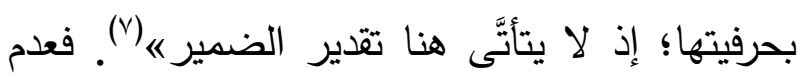

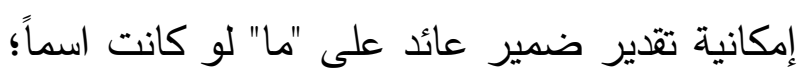

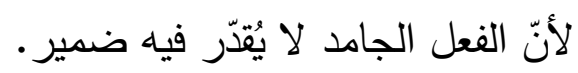

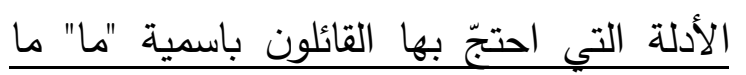
يأتي: ا. أنهّا لو كانت ك "أنْ" لعملت في الفعل كما

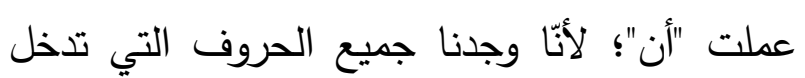

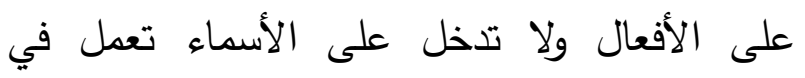

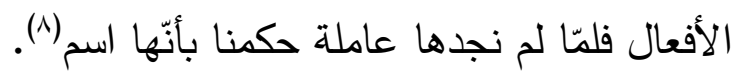

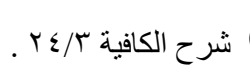

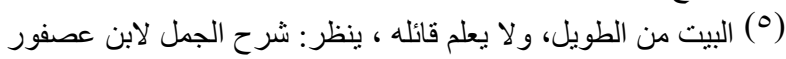

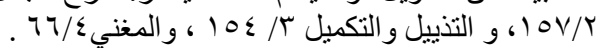

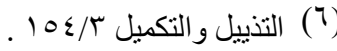

$$
\begin{aligned}
& \text { (Y) المغني (T) (T) }
\end{aligned}
$$

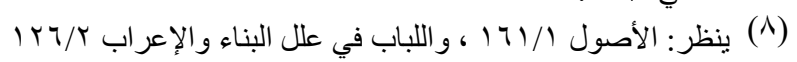

مثل: ومن الذي رزقناهموه؛ لأنكّ إن قدّرته هذا

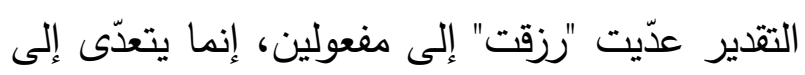

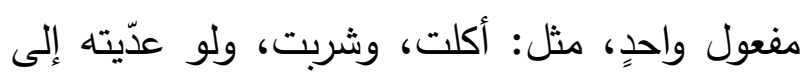

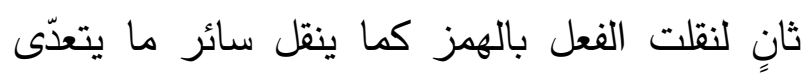

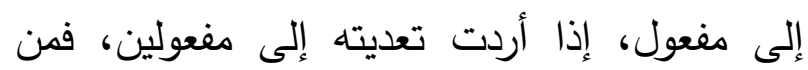

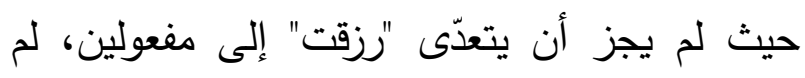

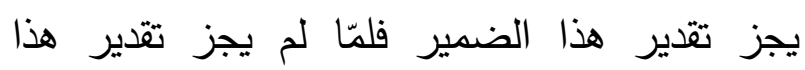

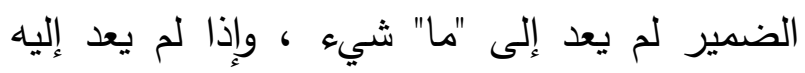
شيء لم يكن اسماً، وإذا ثبت أنّه ليس باسم ثبت أبت أنّه

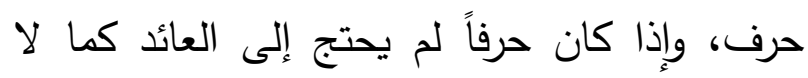
يحتاج إليه "أن" فتقدير : ومما رزقناهم ينفقون : ومن إلى لعن

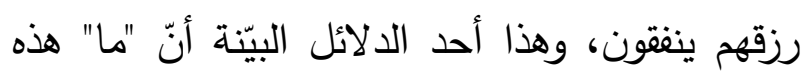
حرفت ليس باسمه ('). ومما يستدل به أيضاً قوله تعالى: إوَضَاقَتُ

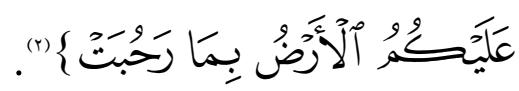
قال ابن يعيش عن هذه الآية: إففيه أيضاً دلالة

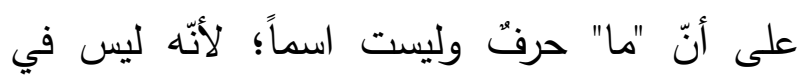

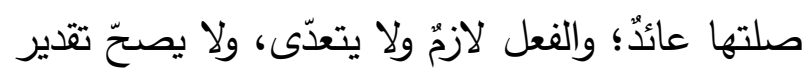
إلحاق الضمير به" (־). وقال الرضي أيضاً عن هذه الآية: أأي: بالرحب الذي رحبته، وليس بوجه؛ إذ لم يعهد الابه

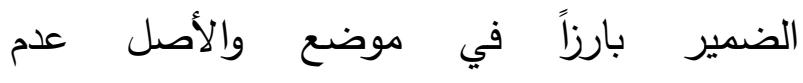


والجواب عن هذا الدليل ذكره العكبري فقال: ذكر لجاز ذلك؛ لأنّ الأصل أنّ العائد يكون مذكوراً

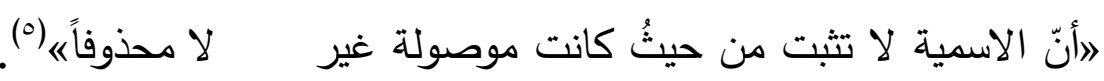
والزّراجح: هو القول بحرفيّة "ما" المصدرية؛ لقوّة

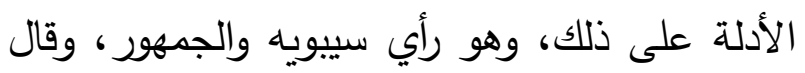

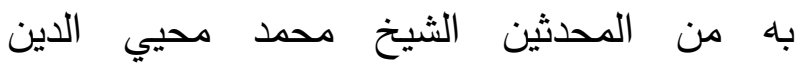

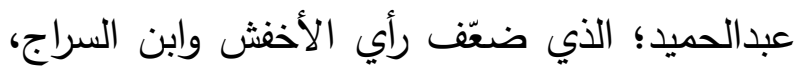
ويحسن أن نختم به المسألة؛ قال الثيخ رحمه الله:

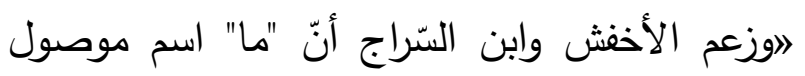

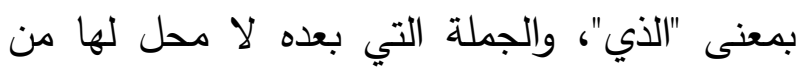

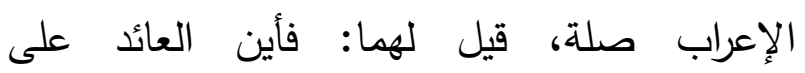
الموصول؛ لأنّ كل موصول اسمي لا بد له من له صلة وعائد؟ فقالا: العائد ضمير محذوف، ملان قلنا لهما: دعوى الحذف باطلة من وجهين: الوجه الأول: أنّه إن كان محذوفاً وجوباً فهو فاسد؛ لأنّ العائد لا يكون حذفه واجباً، ولو كانا

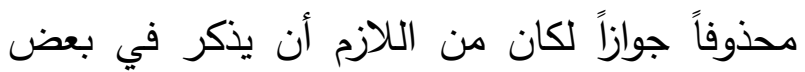
التراكيب، ولكنّا وجدناه لا يظهر في تركيب من لن التراكيب أصلاً؛ وإلا فأنتم مطالبون بأن تجيئوا بشاهد فئاه

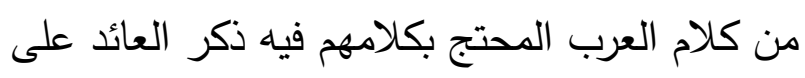
"ما" هذه، ولا سبيل لكم إلى هذا الدليل، فدلّ ذلك لكرد على بطلان دعوى الحذف بنوعيه.

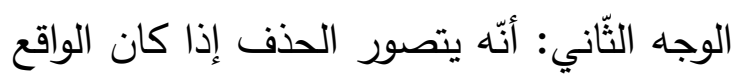
بعد "ما" فعلاً متعديّاً نحو: أعجبني ما اشتريت، فإنك إنك تستطيع أن تقدر أعجبني الذي اشتريته، أمّا إذا كان عاملة، فإن ذلك ليس من حدّ الأسماء ولا علاماتها؛

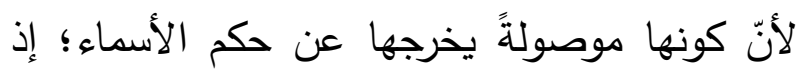
من حكم الأسماء التّمام، وكونها لا تعمّ حكمُ أكثر لخر الحروف فعُلم أنّ الاسمية تثبت بدليل غير هذاهـ|".

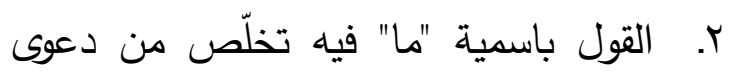

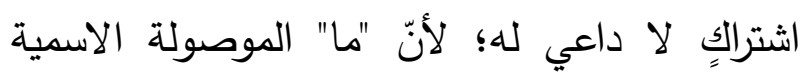
ثابتة باتفاق، وهي موضوعة لما لا يعقل، والأحداث

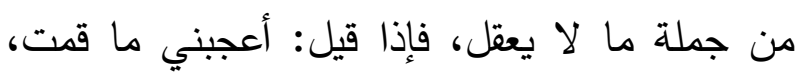
قلنا: التقدير: أعجبني الذي قمته، وهو يعطي معنى

$$
\text { قولهم: أعجبني قيامك(؟). }
$$
والجواب عن هذا الدليل من وجهين ذكره ابن هشام فقال: اويَرُدّ ذلك أنّ نحو: جلستُ ما جلس زيد، تريد به المكان ممتنعٌ مع أنّه ممّا لا يعقل.

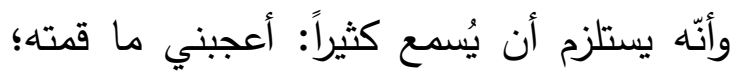
لأنّه عندهما(ץ) الأصل، وذلك غير مسموع. قيل: ولان كئل مككن؛ لأنّ قام غير متعدِّ؛ وهذا خطأ بيّن؛ لأنّ الأن الهاء المقدّرة مفعول مطلق، لا مفعول بهاه (๕).

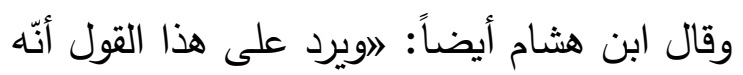

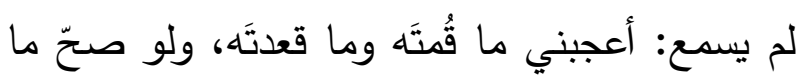


اختلف النحاة في معنى "ما" التعجبية في ما أفعله، على أربعة أقوال، تفصيلها على النحو الآتي: القول الأول: أنّ "ما" نكرة تامة، أي أنها غير موصولة، ولا موصوفة؛ لما يقتضيه التعجب من الإبهام وحسن الابتداء بالنكرة؛ لكون المقصود منه التعجب لا الإخبار المحض، واشتراط تعريف المبتدأ إنّما هو في الخبر المحض، والتقدير عندهم: شيء حسّن زيداً، ويكون ما بعد "ما" من الجملة الفعلية في محل رفع خبر لها. وهذا القول ذهب إليه سيبويـه وجمهور النحاة(r)، وهو أحد الأقوال التي رويت عن الأخفش(ء). القول الثاني: أنّ "ما" التعجبية استفهامية صحبها معنى التعجب، وإلى هذا ذهب الفراء وابن درستويه(0)،ونسبه ابن مالك إلى الكوفيين(")، وهو موافق لقولهم باسمية "أَفْعل" فإنّ الاستفهام المشوب إبـ بالتعجب لا يليه إلا الأسماء(V)، وعلى هذا القول يكون ما بعدها وهو الاسم المشبه بالمفعول باه وفاعله في موضع الخبر لما الاستقهامية المنصوبة بالتعجب. القول الثالث: أنّ "ما" التعجبية موصولة؛ أي:

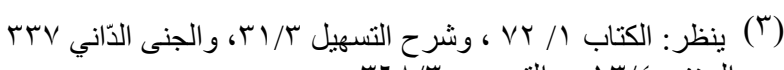

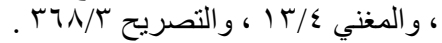

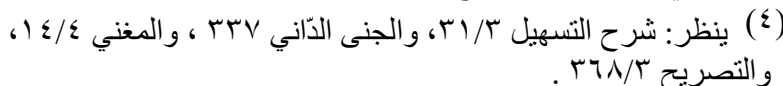

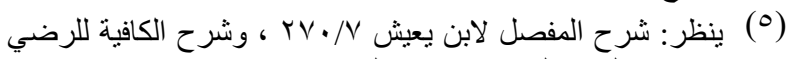

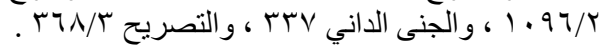

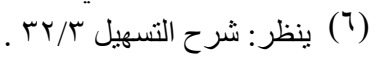

$$
\begin{aligned}
& \text { (V) }
\end{aligned}
$$

الواقع بعد "ما" فعلاً قاصراً مثل ذهب في بيت الشاهد "يسر المرو ما ذهب الليالي" أو جملة اسمية نحو: لا أصحبك ما زيد صديقك، فإنه لا سبيل إلى ملى ادعاء الحذف في هذين الموضعين؛ لأنّك لا تستطيع تقدير المحذوفي('). وبالله التّوفيق.

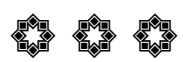

\section{المبحث العاشر: معنى "ما" التّعجبية في "ما}

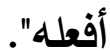

قال الباقولي: 》التعجب يكون بلفظين؛ أحدهما:

ما أفعله، والثاني: أفعل به. فالأول: قولك ما أحسن زيداً، وقد اختلف الناس في "ما" هذه، فذهب سيبويه إلى أنّ "ما" هاهنا نكرة ومعناه شيء، وهو مرفوع بالابتداء وما بعده جملة في موضع خبره.

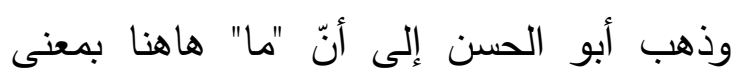

"الذي" موصول، وأحسن صلته، وخبره مضمر، إن تقديره: الذي أحسن زيداً موجود، ولم يُستعمل إظهاره كما لم يستعمل خبر المبتدأ الواقع بعد لولا في قولهم: لولا زيد لهلك عمرو، وهذا الذي ذكره ليس بصحيح؛ لأنّ "ما" إذا كانت موصولة كانت معرفة، والتعجب إنما يكون في شيء مستبدع منكور لا من شيء قد عُرِفِ ووُجد، واللائق به شيء أحسن زيداً وما يقوم مقامه شيء

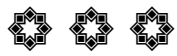

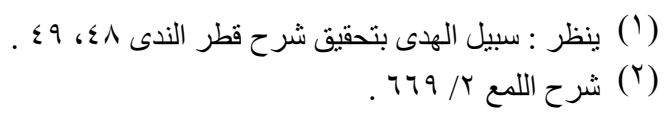


يسوغ عنده أن تكون اسماً تاماً؛ لأنّ "ما" لا تكون

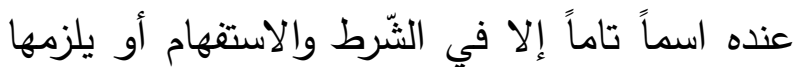

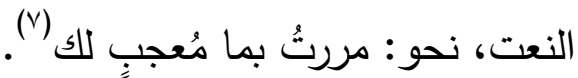
ولم يرتض ابن عصفور قول الأخفش هذا، فقال: اوهذا فاسد؛ لأنّه إذا جعلها موصولة كانت معرفة فيناقض ذلك معنى التّجب؛ لأنّ التعجب لا يكون إلا من خفي السبب. فإن اعتذر بأنّ الإبهام

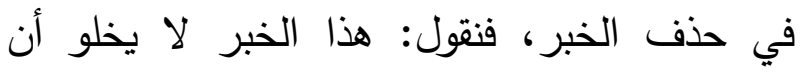
يكون حذفه للدلالة عليه أو لغير دلالة، فإن كان للدلالة عليه فهو بمنزلة الثابت فلا إبهام فيه، وباطل أن يكون لغير دلالة؛ لأنّ الحذف من غير دليل غير فير فئه

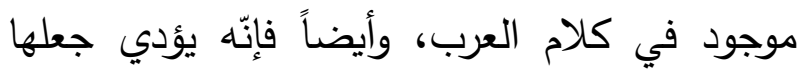

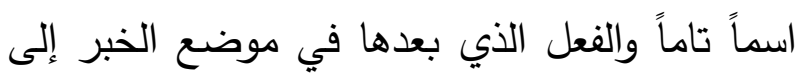

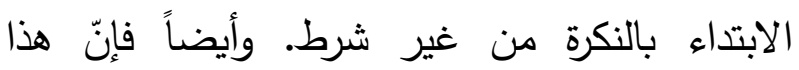
المذهب يؤدي إلى ادعاء حذف مالم يلفظ به في موضع من المواضع، ولو كانت بمنزلة الذي للفظ بخبرها في موضع" (^).

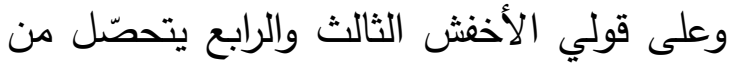
جملة التعجب إفهام وإبهام؛ فحصول الإفهام بذكر لإحتى لتصن المبتدأ وصلته، وحصول الإبهام بالتزام حذف الخبر ؛ إلا أنّ هذين القولين يستلزمان مخالفة النظائر من

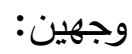

أحدهما: تقدّم الإقهام وتأخير الإبهام، والمعتاد

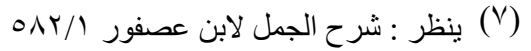

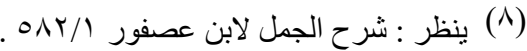

معرفة ناقصة، بمعنى الذي، وما بعدها من الجملة الفعلية صلة لها، لا محل له من الإعراب، والخبر

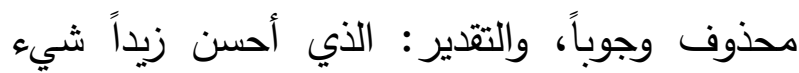
عظيم، وإلى هذا القول ذهب الأخفش ('). ونُسِب إلى ولى جماعة من الكوفيين(r). وهذا هو دهو المشهور هن مذهب الأخفش كما قال ابن يعيش (־).

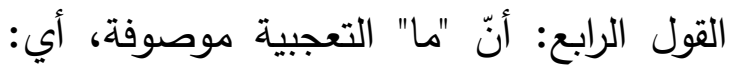
نكرة ناقصة بمعنى شيء، وما بعدها من الجملة

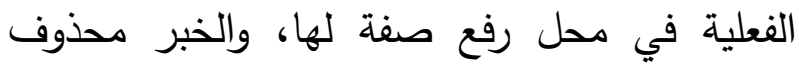
وجوباً، والتقدير : شيء أحسن زيداً عظيم. وإلى هذا القول ذهب الأخفش (ఓ). واستبعد الأخفش أن تكون "ما" اسماً تاماً غير

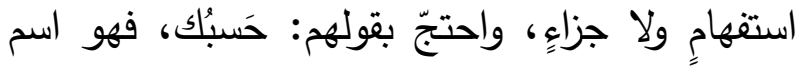
مبتدأ لم يؤت له بخبر ؛ لأنّ فيه معنى النهي فكانت وانت

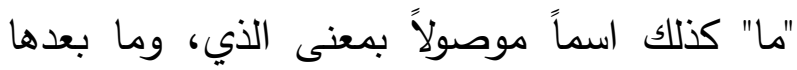
الصلة، والخبر محذوف، تقديره: الذي أحسن زيداً شيء والتُزم حذف الخبر، كما قال الباقولي: لاولم يُشتعمل إظهاره كما لم يستعمل خبر المبتدأ الواقع

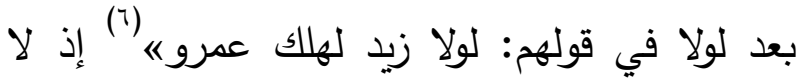

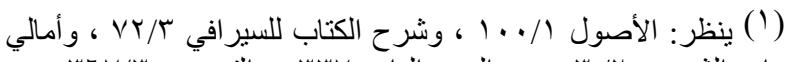

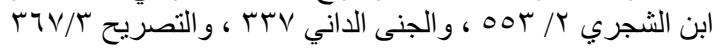

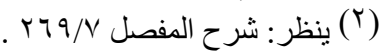

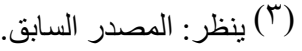

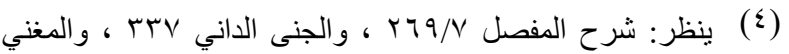

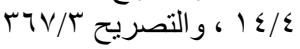

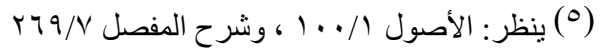

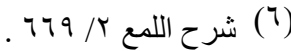


أنّ التعجب إنما يكون فيما جاوز الحدّ المعروف،

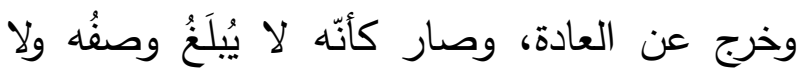

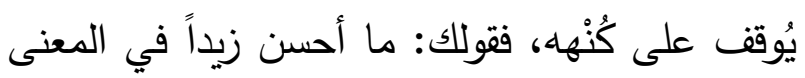

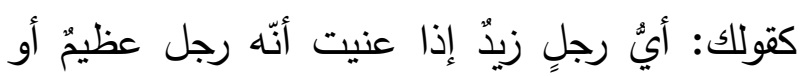

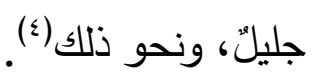

ويرى الرضي أنّ القول بأنّ "ما" استفهامية، وما

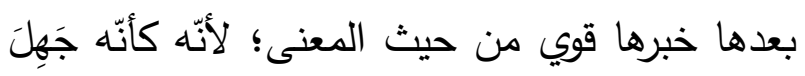

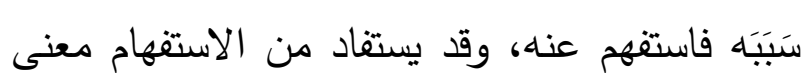

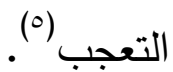

لكنّ كثيراً من العلماء لم يرتضوا هذا القول؛ قال ابن الحاجب: لاوليس بالجيّ؛ لأنّ صيخ الاستفهام لم لم

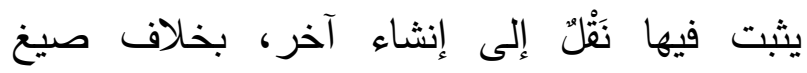
الأخبار، فإنها تُنْقل إلى الإنشاءات كثيراً (ج).

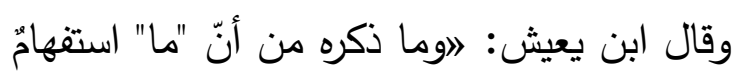

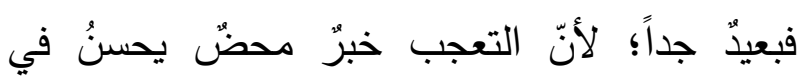

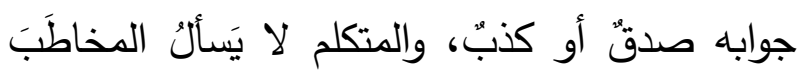

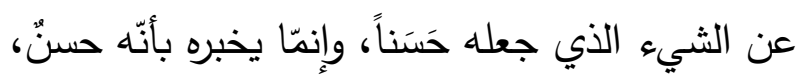

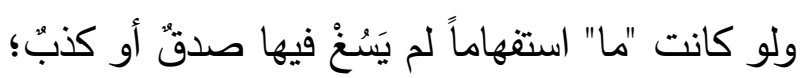

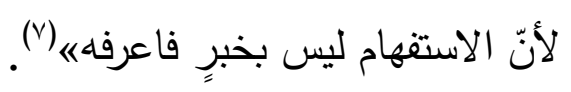

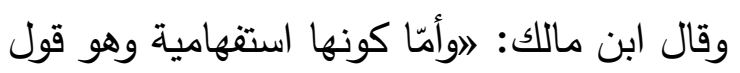

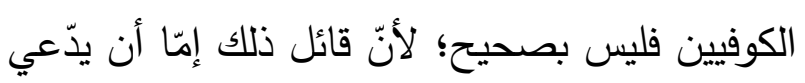

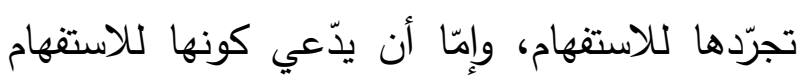

فيما تضمّن من الكلام إفهاماً وإبهاماً تقديم ما به الإبهام وتأخير ما به الإقهام، كما فعل بضمير لفئ

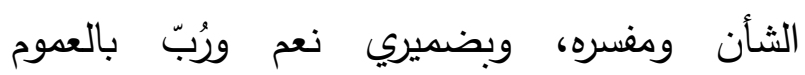
والتخصيص وبالمميز والتمييز وأشباه ذلك. ثانيهما: كون الخبر ملتزم الحذف دون شيء ولتئ يسد مسدّه، والمعتاد في الخبر الملتزم الحذف أن يسدّ مسدّه شيء يحصل به استطالة كما فعل بعد لولا

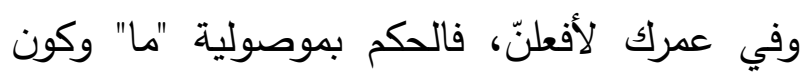
الخبر محذوفاً دون استطالة حكم بما لا نظير لله، فلم يعوّل عليه ولا أجيب الداعي إليه('). ومن ردود العلماء على الأخفش في قوله إنّ إنه "ما" موصولة؛ ما قاله ابن الحاجب: لاوفيه تعسّف؛

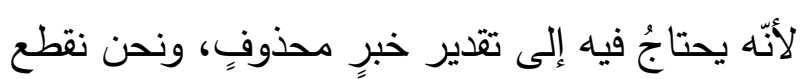

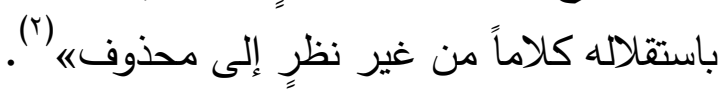

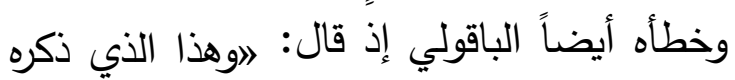
ليس بصحيح؛ لأنّ "ما" إذا كانت موصولة كانت

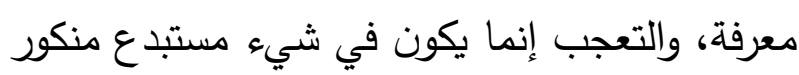

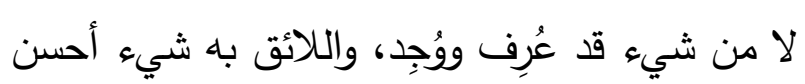

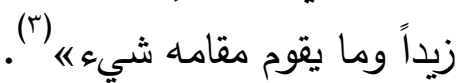

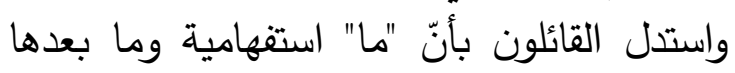

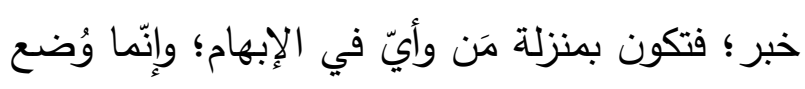
هذا في التعجب لأجل أنّ التعجب فيه إبهامٌ؛ وذلك

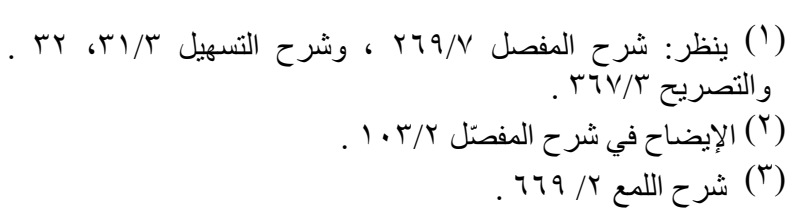




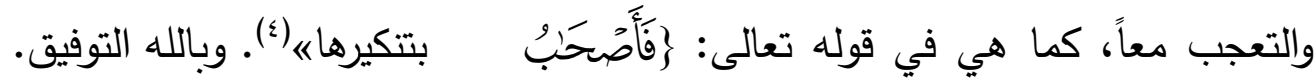

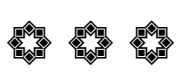

\section{الخاتمة}

الحمد لله الَّي بنعمته تتم الصّالحات، والصّلاة

والسّام على خير خلق الله سيدنا ونبينا محمد، وعلى آله وصحبه أجمعين.

وبعد؛ فقد انتهيت من دراسة تعقّات الباقولي

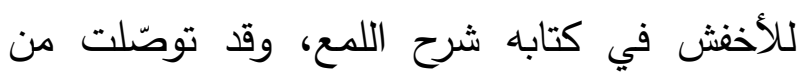
خلال دراستها إلى نتائج من أهمها:

ا. أنّ الباقولي بصري المذهب، ويرجح ويختار

ما يوافق مذهبهم غالباً.

r. أنّ الباقولي محق في كثير من تعقبّاته على

الأخفش؛ وذلك ظاهر لمن تأمل تلك المسائل فئل فعباته

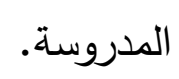

r. أنّ الرّاجح الذي يميل إليه الباحث في كثير

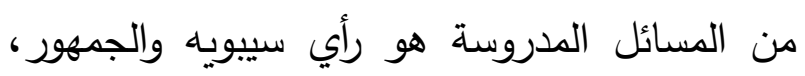
وهو ما تعضده الأدلة والثّواهد.

ع. أنّ الباقولي صاحب شخصية علمية مديزه وله تعقّات ومواقف متعددة على كثير من النحاة، كالخليل بن أحمد، ويونس بعن وموات حبيب، والفراء،

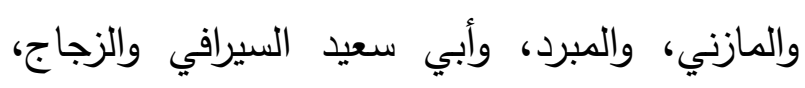

$$
\text { وأبي علي الفارسي، وغيرهم. }
$$

ه ـ أنّ الباقولي متأثر في توجيهاته ونقوله بأبي علي

$$
\text { الفارسي، وينقل عنه في كثير من كتبه. }
$$

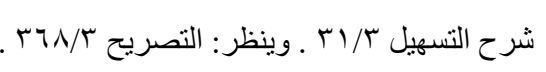

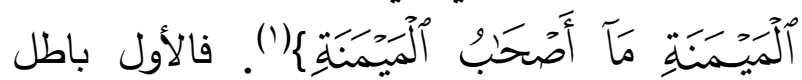

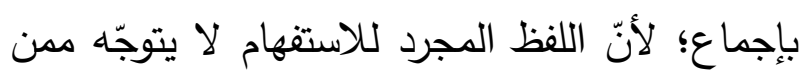

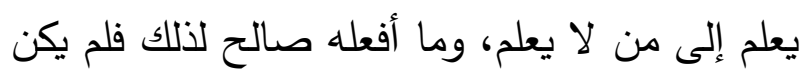
لمجرد الاستفهام. والثاني أيضاً باطل؛ لأنّ الاستفهام

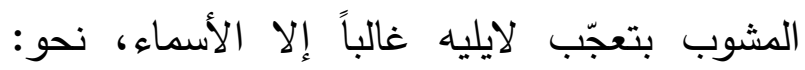

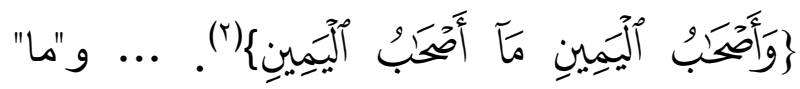

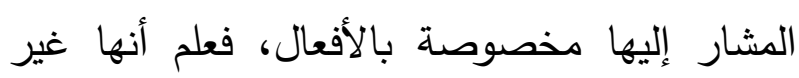

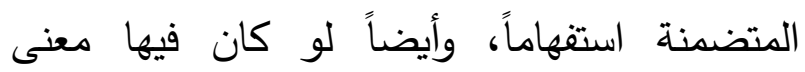

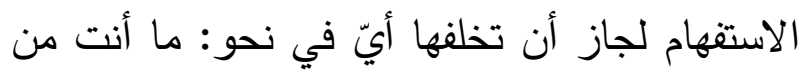
سيّد؛ لأنّ استعمال أيّّ في الاستفهام المتضمّن تعجّاً

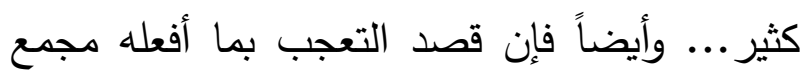
عليه، وكونه مشوباً بالاستفهام، أو ملموحاً فيه الاستفهام زيادة لا دليل عليها فلا يلتفت إليهاها"( ال. والرّاجح في هذه المسألة هو ما ذهب إنبا لإليه

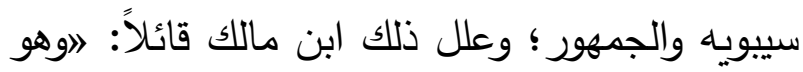

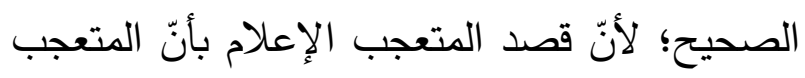

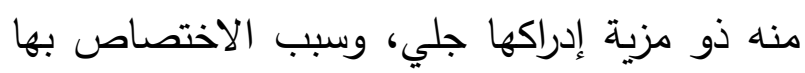
خفي، فاستحقت الجملة المعبّر بها عن ذلك أن تفتتح بنكرة غير مختصة؛ ليحصل بذلك إبهام متلوّ بإفهام،

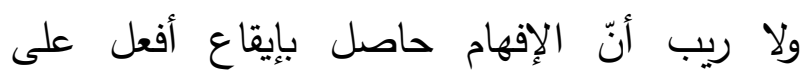
المتعجب منه إذ لا يكون إلا مختصّاً، فيتعيّن كون الإفام

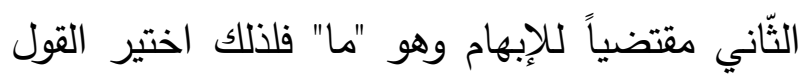


r. الأصول في النحو، لابن السراج، تحقيق

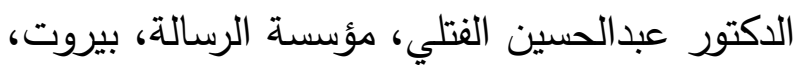
ط)

ـ. إعراب القرآن، لأبي جعفر النحاس، تحقيق

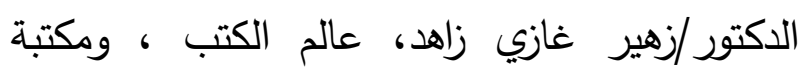

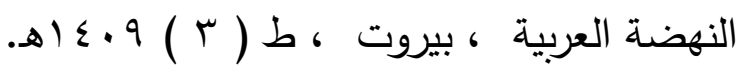

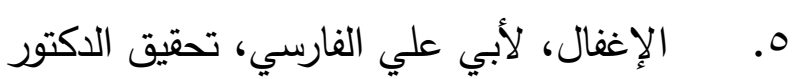

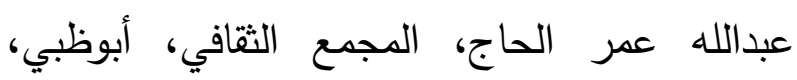

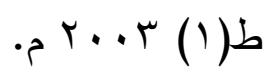

7.

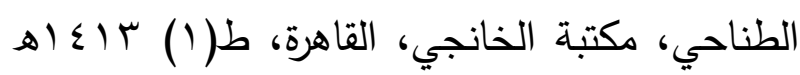

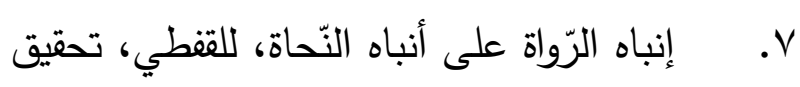

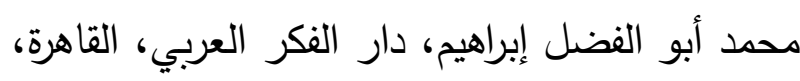

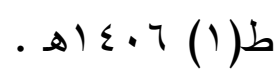
^. الإنصاف في مسائل الخلاف بين النحويين البصريين والكوفيين، لأبي البركات الأنباري، بعناية

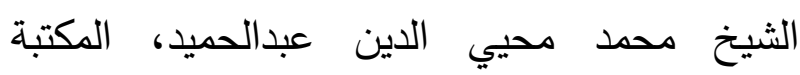

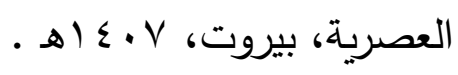

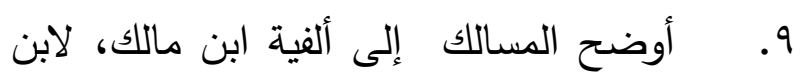

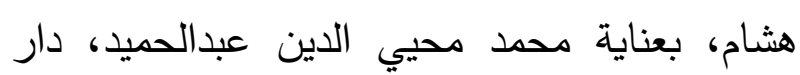

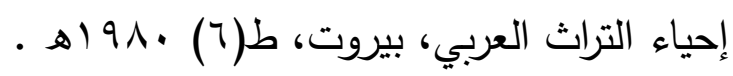

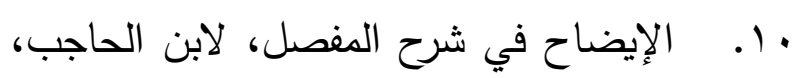

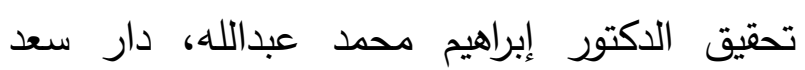

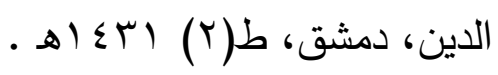

T. أنّ الباقولي استعمل مصطلحات عدة للتعبير عن تعقّبه للأخفش، وفي أغلبها قسوة في العبارة والرد

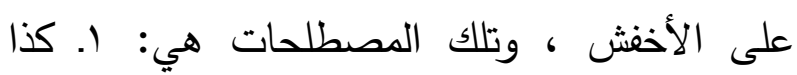
زعمه الأخفش ، أو على زعم أبي الحسن، أو وزعم الأف الته

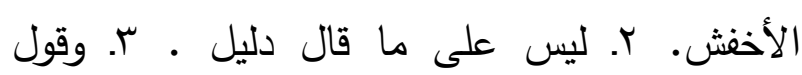

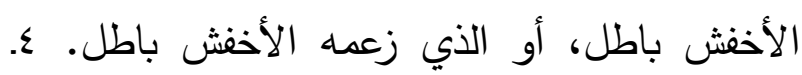
والأمر بخلاف ما زعم أبو الحسن ه. ونحن لانجيز

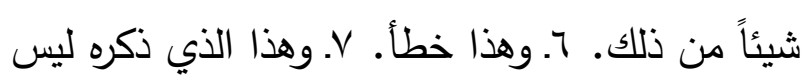
بصحيح. وفي الختام أرجو أن أكون قد وفقت فيما كتبته في

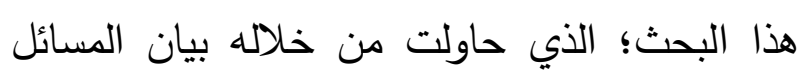
التي تعقّب فيها الباقولي الأخفش، وهل كان محقّاَ في

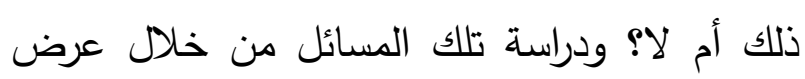
أقوال العلماء فيها، وبيان الرّاجح في تلك المسائل،

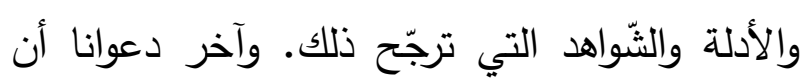
الحمد لله رب العالمين، وصلّى الله على سيدنا ونبينا محمد وعلى آله وصحبه وسلم.

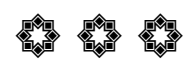

\section{فهرس المصادر والمراجع}

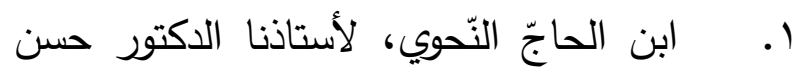

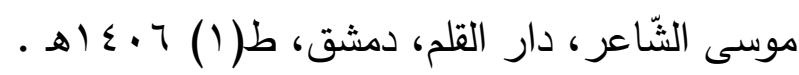

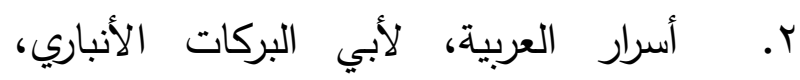

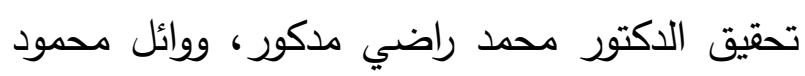

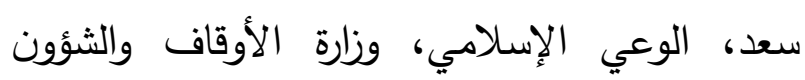
الإسلامية، الكويت، الإصدار الخامس والتسعون، ولإن، ط) (1) ד (1) 
19. ـصصيل عين الذّهب من معدن جواهر الأدب في علم مجازات العرب، للأعلم الثنتمري، تحقيق الدكتور زهير عبدالمحسن سلطان، مؤسسة

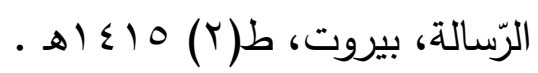
• . . . التذييل والتكميل في شرح كتاب التسهيل، لأبي حيّان الأندلسي، تحقيق الدكتور حسن هنداوي،

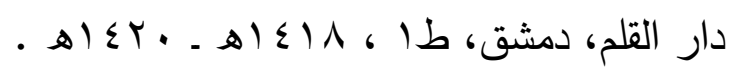
ا Y. التسهيل، لابن مالك، تحقيق محمد كامل بركات، دار الكاتب العربي، القاهرة، ط( ) (1 ) - ه Y. . التصريح بمضمون التوضيح ، للشيخ خالد الأزهري ، تحقيق الأستاذ الدّكتور عبد الفتاح بحيري إبراهيم ، الزهراء للإعلام العربي القاهرة ، طاه(1) . إ) ( 1 ، ه rr. تعليق الفرائد على تسهيل الفوائد، للدماميني، تحقيق الدكتور محمد بن عبدالرحمن المفدّى، ط(1)

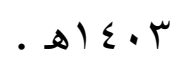
צ r. التعليقة على كتاب سيبويه، لأبي علي الفارسي، تحقيق وتعليق د. عوض القوزي، مطبعة

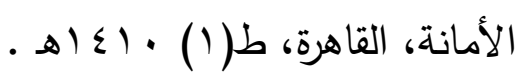
هץ. التفسير البسيط ، للواحدي ، تحقيق مجموعة من الباحثين ، عمادة البحث العلمي ، جامعة الإمام

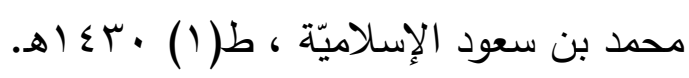
Tr. تهذيب اللغة، لأبي منصور الأزهري، تحقيق محمد أبو الفضل إبراهيم، الدار المصرية للتأليف والترجمة، مطابع سجل العرب، ؛ 97 م.
1ا. البحر المحيط ، لأبي حيّان الأندلسي

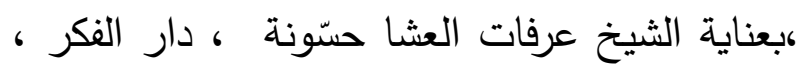

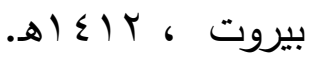
r ا. البسيط في النحو، لابن العلج، تحقيق د.

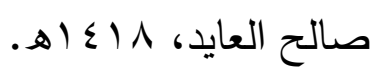
با. . بغية الوعاة في طبقات اللغويين والنّحاة، للسيوطي، تحقيق محمد أبو الفضل إبراهيم، المكتبة العصريـة، بيروت. ع ا. البيان في شرح اللمع ، للشريف عمر بن إبراهيم الكوفي، دراسة وتحقيق الدكتور علاء الدّين

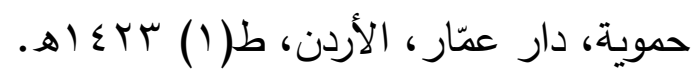
1 . البيان في غريب إعراب القرآن، لأبي البركات الأنباري، تحقيق الدكتور طه عبدالحميد طه، الهيئة المصرية العامة للكتاب، القاهرة، ط(1) . $1 \leqslant$. . 71. التبصرة والتذكرة، لأبي محمد عبدالله بن علي الصّيمري، تحقيق الدكتور فتحي أحمد مصطفى عليّ الدين، جامعة أم القرى، مكّة المكرمة، مركز البحث العلمي وإحياء التراث الإسلامي، طا(1) . I) $\varepsilon \cdot Y$ ، التبيان في إعراب القرآن ، للعكبري تحقيق علي محمد البجاوي ، دار الجيل ، بيروت

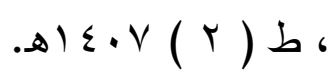
11. التبيين عن مذاهب النحويين البصرين والكوفيين، لأبي البقاء العكبري، تحقيق ودراسة الدكتور عبدالرحمن بن سليمان العثيمين، دار الغرب الإسلامي، بيروت، ط( (1) 7 ، ؛ أه . 
هr. ديوان النّابغة الذبياني، تحقيق محمد أبو الفضل إبراهيم، دار المعارف، القاهرة، ط(ب) . جس. ديوان بشر بن أبي خازم، تحقيق الدكتور

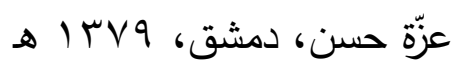
V r. ديوان جرير ، بشرح محمّد بن حبيب، تحقيق

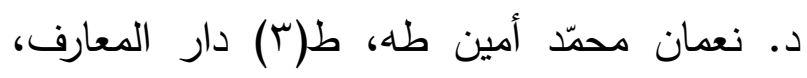

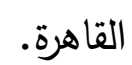
م ז. رصف المباني في حروف المعاني، للمالقي، تحقيق الدكتور أحمد محمد الخرّاط، دار القلم، رئ،

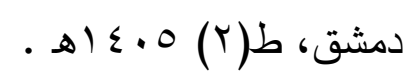
وس. السبعة في القراءات ، لابن مجاهد ، تحقيق الدّكتور شوقي ضيف ، دار المعارف ، القاهرة ، • ط) • ع. سرّ صناعة الإعراب ، لابن جنّي ، تحقيق الدّكتور حسن هنداوي ، دار القلم ، دمشق ، طاب( ) . 1 . 0 اء. شرح أبيات مغني اللبيب، لعبدالقادر البغدادي، تحقيق عبدالعزيز رباح، و أحمد يوسف

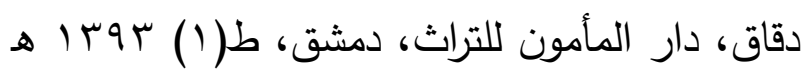

Y Y. شرح أشعار الهذليين، صنعة أبي سعيد السّكري، تحقيق عبدالسّتار أحمد فرّاج، مكتبة دار العروبة، القاهرة. rع. شرح الأشموني وبهامشه حاشية الصّبان، دار إحياء الكتب العربية، عيسى البابي الحلبي

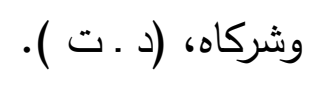

rV شرح ودراسة وتحقيق يُسْري عبدالغني عبدالله، دار

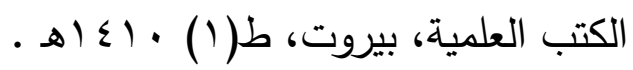
^ץ. الجنى الداني في حروف المعاني، للمرادي، تحقيق الدكتور فخر الدين قباوة، والأستاذ محمد نديم فاضل، دار الكتب العلمية، بيروت، ط( (1) باء اهـ. وץ. جواهر القرآن ونتائج الصّنعة، للباقولي، تحقيق الدكتور محمد الدالي، دار القلم، دمشق، ط ط (1) (1) • ب. الحجّة للقراء السبعة، لأبي عليّ الفارسي، تحقيق بدر الدين قهوجي وبشير جويجاني، دار المأمون، دمشق، ط( (1) • ع أهـ اس. خزانة الأدب ولب لباب لسان العرب، لعبدالقادر البغدادي، تحقيق عبدالسّلام هارون، مكتبة الخانجي، القاهرة، ط(ب) 9 . ـ 1 هـ. rr. الدر المصون في علوم الكتاب المكنون

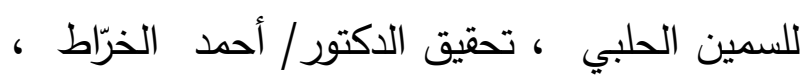
دار القلم ، دمشق ، ط (1) 7 . ؛ اهـ. سب. ديوان الأعشى " كتاب الصّبح المنير في شعر أبي بصير " وفيه شعر الأعشى الكبير والأعْشَيْنَ الآخرين، تحقيق رودلف جاير، فينا 9 TV الكويت ع ا. ديوان العجّاح ، رواية الأصمعي وشرحه، تحقيق د. عزّة حسن، دار الثّرق العربي، بيروت، ط 


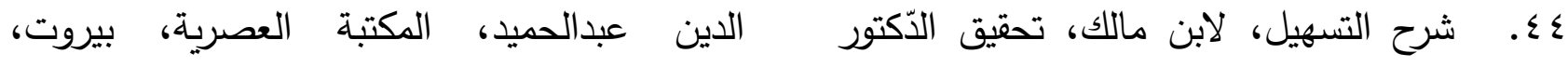
عبد الرحمن السيّّ والدّكتور محمّد بدوي المختون،

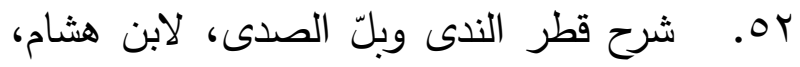
هجر للطباعة والنشر، القاهرة، ط(1) • (ـ الهـ

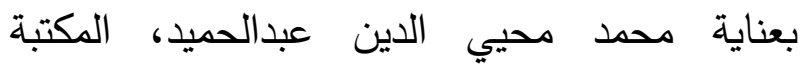
0ء. شرح التسهيل، للمرادي، تحقيق ودراسة

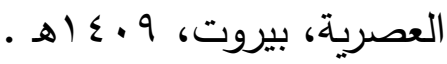

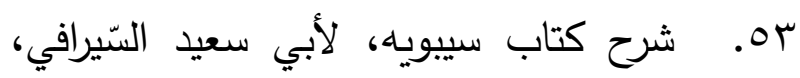

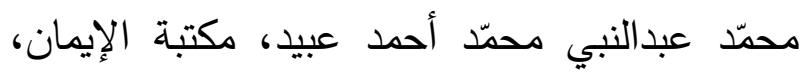

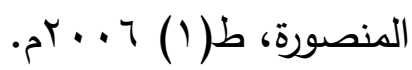
تحقيق د. فهمي أبو الفضل، دار الكتب والوثائق

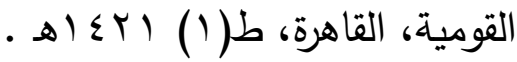
ـ. شعر زهير بين أبي سلمى، صنعة الأعلم الشنتمري، تحقيق الدكتور فخر الدين قباوة، دار

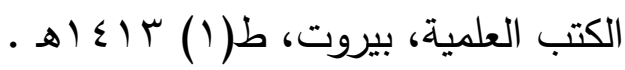

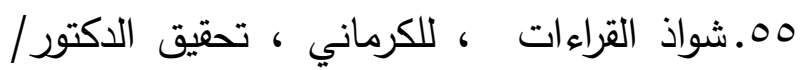

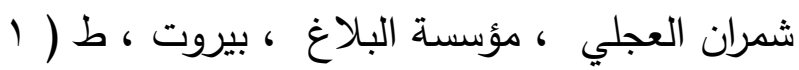
07.الصّحاح، للجوهري، تحقيق أحمد عبدالغفار

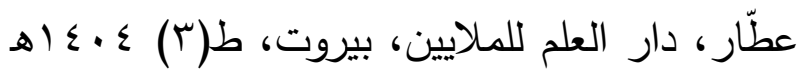
9乏. شرح جمل الزّجّاجي ، لألابن عصفور تو.ov

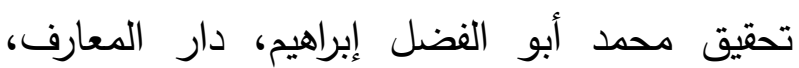

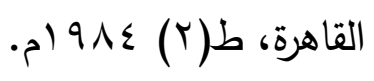

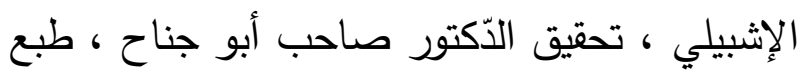

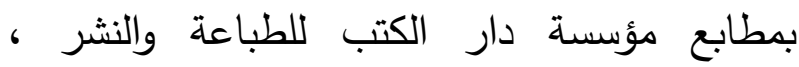
. $) \leqslant \ldots$

هـ العين، للخليل بن أحمد الفراهيدي، تحقيق •0. شرح شافية ابن الحاجب، للرضي، تحقيق

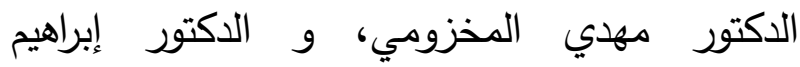
السّامرائي، منشورات الأعلميّ للمطبوعات، بيروت،

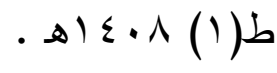
09. الفاخر في شرح جمل عبدالقاهر، لمحمد بن أبي الفتح البعلي، تحقيق الدكتور مددوح محمد

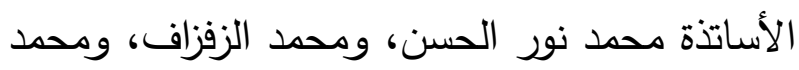
محيي الدين عبدالحميد، دار الكتب العلمية، بيروت، ولهُ طا ط) 10. شرح شذور الذهب في معرفة كلام العرب،

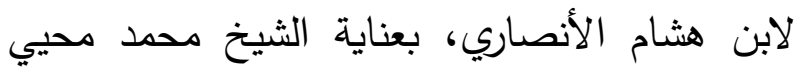


الزوتي، منشورات جامعة قاريونس، بنغازي، ط(1) . 2) $99 \varepsilon$

• V. المحتسب في تبيين وجوه شواذ القراءات والإيضاح عنها ، لابن جنّي ، تحقيق علي النجدي ناصف ، والدكتور عبدالحليم النجار ، والدكتور /

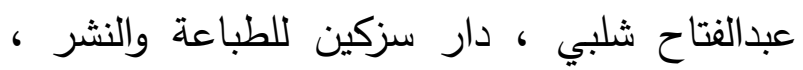

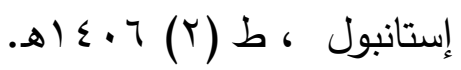
( V. مختار الصّحاح، للرازي، إخراج دائرة المعاجم في مكتبة لبنان، بيروت، 9 أم. Y.V مختار تذكرة أبي علي الفارسي وتهذيبها ، لأبي الفتح عثمان بن جني، تحقيق د. حسين أحمد بوعباس ، مركز الملك فيصل للبحوث والدراسات

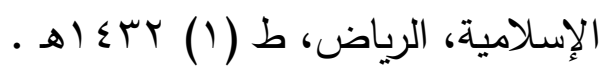
r.V.مختصر في شواذ القرآن، لابن خالويه، عني بنشره ج• برجشتراسر ، دار الهجرة. ع V. المرتجل ، لابن الخشّاب، تحقيق ودراسة علي

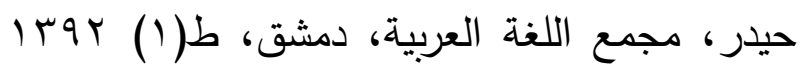

ه V. المسائل الشيرازيّات، لأبي علي الفارسي، تحقيق د. حسن هنداوي، كنوز أثبيليا، الرياض، ط(1) . $) \leqslant Y \leqslant$

T. VT المسائل العسكرية، لأبي علي الفارسي، تحقيق الدكتور محمد الثّاطر، مطبعة المدني، القاهرة، ط) (1) (1) .VV المسائل المشكلة المعروفة بالبغداديات، لأبي علي الفارسي، دراسة وتحقيق صلاح الدين عبدالله

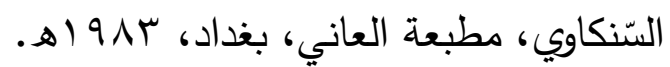

خسارة، المجلس الوطني للثقافة والفنون والآداب،

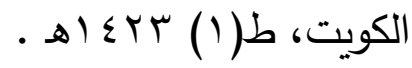
• 7 ـ الفوائد والقواعد " شرح اللمع " للثمانيني، دراسة وتحقيق الدكتور عبدالوهاب محمود الكحلة، مؤسسة

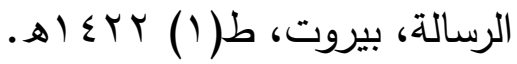

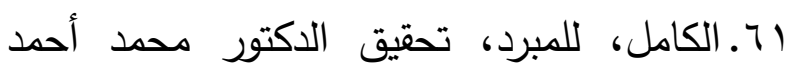

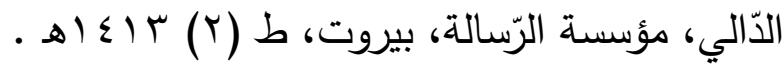

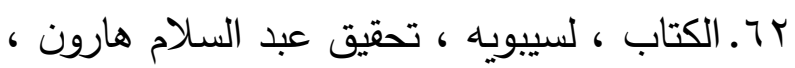

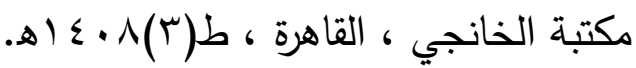
با.كتاب الشعر، أو شرح الأبيات المشكلة الإعراب، لأبي علي الفارسي، تحقيق الدكتور محمود

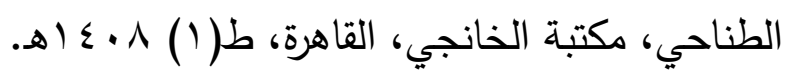

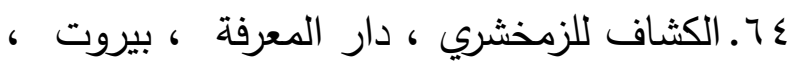
. (د.) 7. كشف المشكلات وإيضاح المعضلات للباقولي ، تحقيق د. محمد أحمد الدالي ، مطبوعات مجمع

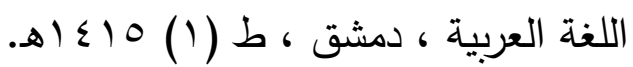
77. اللباب في علل البناء والإعراب، لأبي البقاء العكبري، تحقيق الدكتور عبدالإله النبهان، دار الفكر

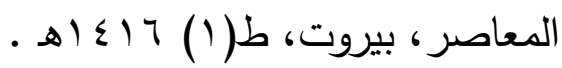

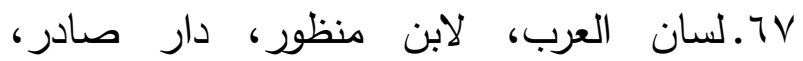

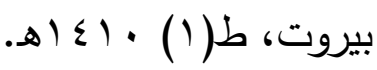
1 7. لهجة ربيعة وآثرها في الدراسات اللغوية والقرآنية، الدكتور مثنى فؤاد الخالدي، دار المأمون، الأردن، طا(1) (1) اله (1) 7. المتبّع في شرح اللهع، لأبي البقاء العكبري، دراسة وتحقيق الدكتور عبدالحميد حد محمود 


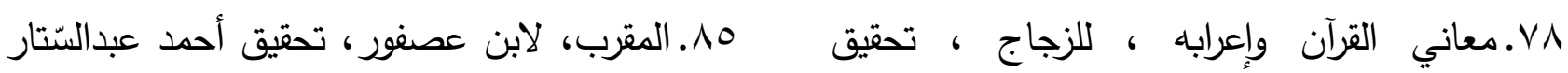

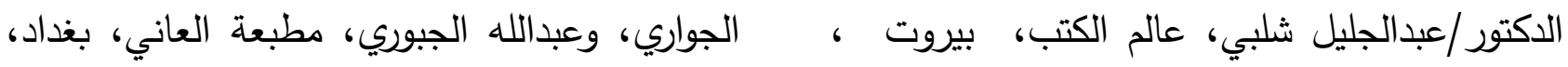

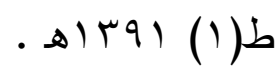

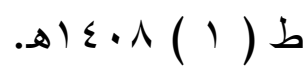

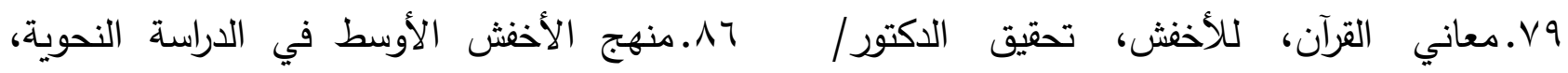

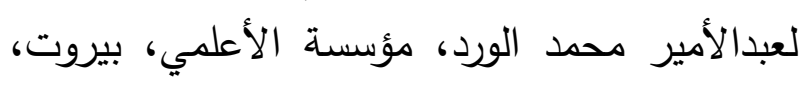

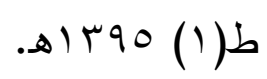

ا.Av نتائج الفكر في النحو، للسهيلي، تحقيق أستاذنا

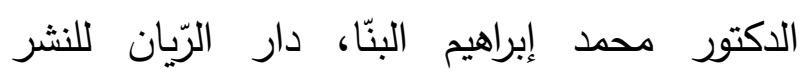

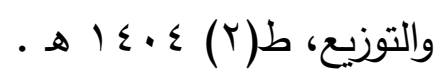

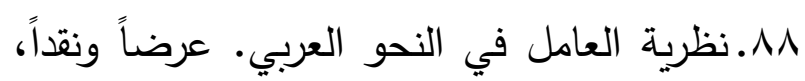

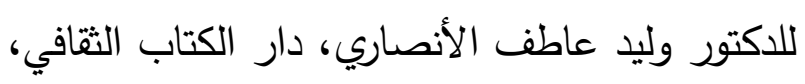

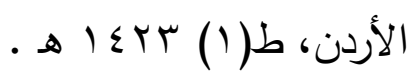

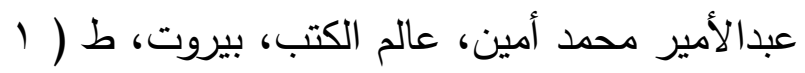

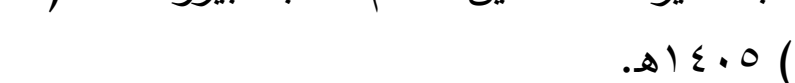
•ـ. معاني القرآن، للفراء، تحقيق محمد علي النجار

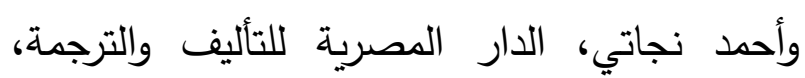
القاهرة، ( د.ت). ادم.معجم الأدباء، لياقوت الحموي، تحقيق الدكتور

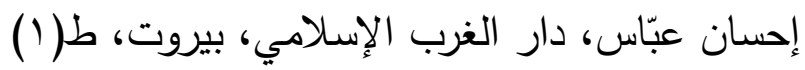
.

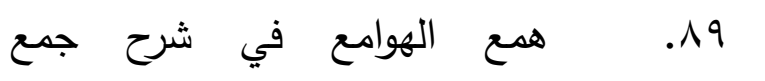

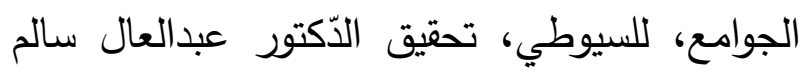

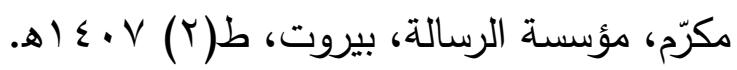

r. بعجم مقاييس اللغة، لابن فارس، تحقيق

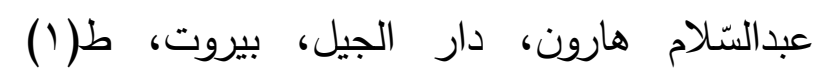
. إ rم. مغني اللبيب عن كتب الأعاريب، لابن هشام

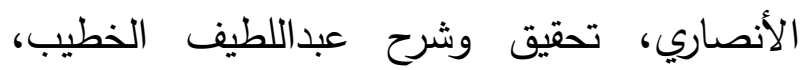

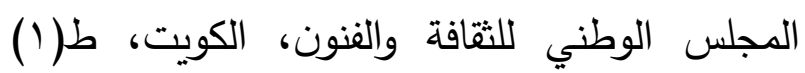
(ه) عـ. المقتضب ، للمبرّد ، تحقيق محمّد عبد الخالق عضيمة، عالم الكتب ، بيروت، (د.ت). 


\title{
A Presentation and Discussion of Jameh Al-Uloom Al-Baquli's rejoinder to Al-Akhfash in his explanation of Al-Luma
}

\author{
Dr. Ibrahim bin Salim Al-Saedy \\ Associate Professor \\ Department of Linguistics, Faculty of \\ Arabic Language, Islamic University of Madinah
}

The research deals with the rejoinder of Jami al-Uloom al-Baquli to al-Akhfash in his book Sharh alLuma '. I started the research with a preface which includes a brief introduction of al-Akhfash and alBaquli due to the large number of studies on them, then I clarified the concept of (Ta'aqubaat) rejoinder, after which I began to study those rejoinders through ten issues.

I presented in the first topic the declension of the word 'Fii', when it means "'Fam' mouth if it is not annexed, and I discussed in the second topic about the regularity of the agent through the reducer and the reduced and then I devoted the third topic to usage of "Lata", and in the fourth topic I spoke about the determinant of nominative case of concomitant patient, and the fifth topic was devoted to discussing the apposition of two passive elements to two regents, and the sixth topic was devoted to putting the status before its regent if it is adverb, then I gave a detailed explanation in the seventh topic about the regent for adjective, and the opinions of syntacticians on that, and in the eighth topic I discussed about "Ayyu" (Oh) between been an adjective and conjuctive noun, then I presented in the ninth topic " Maa of originality "between nominative and particle, Then I concluded the discussion in the tenth topic about the meaning of "Maa" of exclamation mood in "Maa Af'alau".

I used the descriptive, inductive analytical approach in the course of studying and discussing these issues, and then the conclusion which I stated the most important results of this research.

Key words: Ta'aqubat (Rejoinder) - Al-Baquli - Al-Akhfash - Sharh al-Luma 